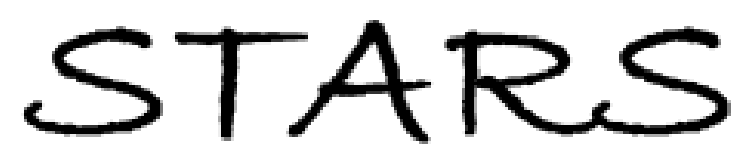

University of Central Florida

STARS

\title{
An Optimized Kinetics Model For Oh Chemiluminescence At High Temperatures And Atmospheric Pressures
}

Joel Hall

University of Central Florida

Part of the Mechanical Engineering Commons

Find similar works at: https://stars.library.ucf.edu/etd

University of Central Florida Libraries http://library.ucf.edu

This Masters Thesis (Open Access) is brought to you for free and open access by STARS. It has been accepted for inclusion in Electronic Theses and Dissertations, $2004-2019$ by an authorized administrator of STARS. For more information, please contact STARS@ucf.edu.

\section{STARS Citation}

Hall, Joel, "An Optimized Kinetics Model For Oh Chemiluminescence At High Temperatures And Atmospheric Pressures" (2005). Electronic Theses and Dissertations, 2004-2019. 4458.

https://stars.library.ucf.edu/etd/4458

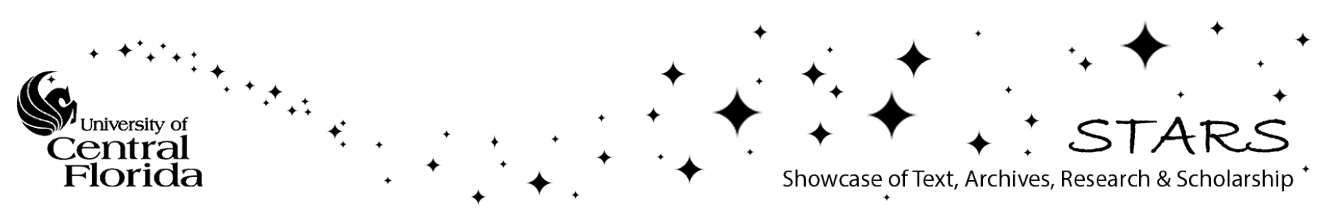




\section{AN OPTIMIZED KINETICS MODEL FOR OH CHEMILUMINESCENCE AT HIGH TEMPERATURES AND ATMOSPHERIC PRESSURES}

by

JOEL M. HALL

B.S. University of Central Florida, 2004

A thesis submitted in partial fulfillment of the requirements

for the degree of Master of Science

in the Department of Mechanical, Materials \& Aerospace Engineering

in the College of Engineering and Computer Science

at the University of Central Florida

Orlando, Florida

Fall Term

2005 
(C) 2005 Joel M. Hall 


\begin{abstract}
Chemiluminescence from the $\mathrm{OH}(\mathrm{A} \rightarrow \mathrm{X})$ transition near $307 \mathrm{~nm}$ is a commonly used diagnostic in combustion applications such as flame chemistry, shock-tube experiments, and reacting-flow visualization. Measurements of the chemiluminescent intensity provide a simple, cost-effective, non-intrusive look at the combustion environment. The presence of the ultraviolet emission is often used as an indicator of the flame zone in practical combustion systems, and its intensity may be correlated to the temperature distribution or other parameters of interest. While absolute measurements of the ground-state $\mathrm{OH}(\mathrm{X})$ concentrations are well-defined, there is no elementary relation between emission from the electronically excited state $\left(\mathrm{OH}^{*}\right)$ and its absolute concentration. Thus, to enable quantitative emission measurements, a kinetics model has been assembled and optimized to predict $\mathrm{OH}^{*}$ formation and quenching at combustion conditions. Shock-tube experiments were conducted in mixtures of $\mathrm{H}_{2} / \mathrm{O}_{2} / \mathrm{Ar}, \mathrm{CH}_{4} / \mathrm{O}_{2} / \mathrm{Ar}$ and $\mathrm{CH}_{4} / \mathrm{H}_{2} / \mathrm{O}_{2} /$ Ar with high levels of argon dilution (>98\%). Elementary reactions to model $\mathrm{OH}^{*}$, along with initial estimates of their rate coefficients, were taken from the literature. The important formation steps follow.
\end{abstract}

$$
\begin{gathered}
\mathrm{CH}+\mathrm{O}_{2} \leftrightarrows \mathrm{OH}^{*}+\mathrm{CO} \\
\mathrm{H}+\mathrm{O}+\mathrm{M} \leftrightarrows \mathrm{OH}^{*}+\mathrm{M} \\
\mathrm{H}+\mathrm{OH}+\mathrm{OH} \leftrightarrows \mathrm{OH}^{*}+\mathrm{H}_{2} \mathrm{O}
\end{gathered}
$$

Sensitivity analyses were performed to design experiments at conditions most sensitive to the formation reactions. A fitting routine was developed to express the key rate parameters as a function of a single rate, $\mathrm{k}_{1}$ at the reference temperature $(1490 \mathrm{~K})$. With all rates so expressed, 
$\mathrm{H}_{2} / \mathrm{CH}_{4}$ mixtures were designed to uniquely determine the value of $\mathrm{k}_{1}$ at the reference temperature, from which the remaining rate parameters were calculated. Quenching rates were fixed at their literature values. Comparisons to predictions of previously available models show marked improvement relative to the new shock-tube data. An approach for using this work in the calibration of further measurements is outlined taking examples from a recent ethane oxidation study. The new model qualitatively matches the experimental data over the range of conditions studied and provides quantitative results applicable to real combustion environments, containing higher-order hydrocarbon fuels and lower levels of dilution in air. 


\section{ACKNOWLEDGMENTS}

Partial support for this research came from The Aerospace Corporation MOIE program with Michael Zambrana (SMC/AXE) as cognizant manager. The assistance of Danielle Kalitan, Anthony Amadio, and Jaap de Vries (UCF) in the laboratory and helpful discussions with Dr. Gregory Smith (SRI) are appreciated. The content of this work was made possible by the guidance and expertise of Dr. Eric Petersen, whose assistance throughout is greatly appreciated. 


\section{TABLE OF CONTENTS}

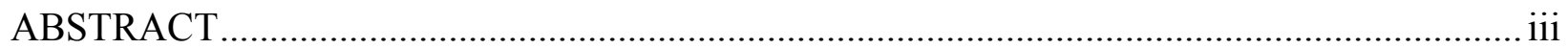

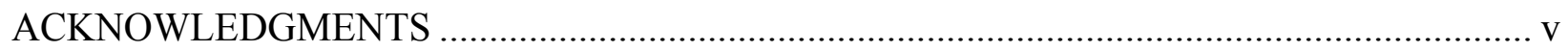

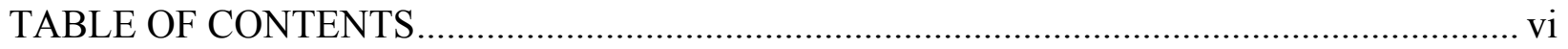

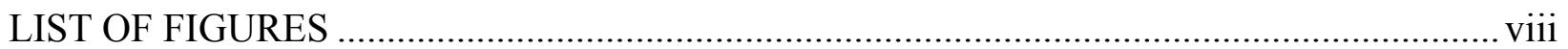

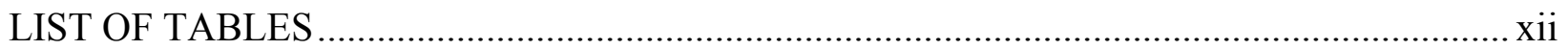

LIST OF ACRONYMS/ABBREVIATIONS ………............................................................

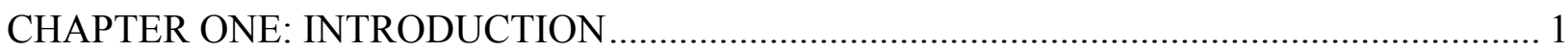

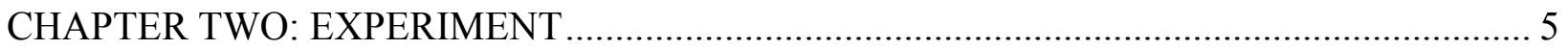

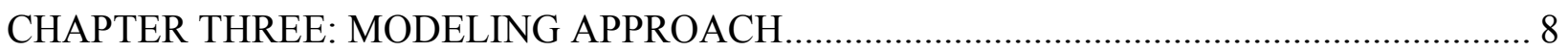

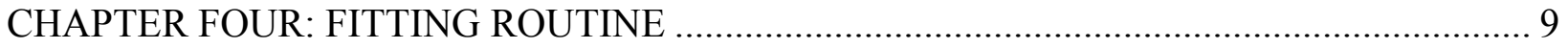

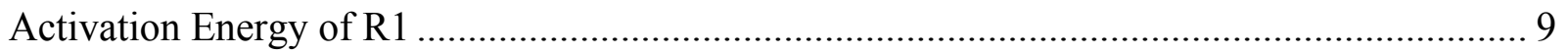

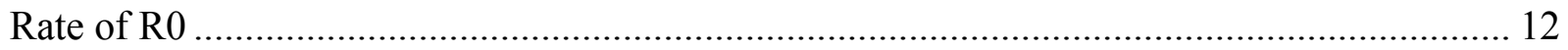

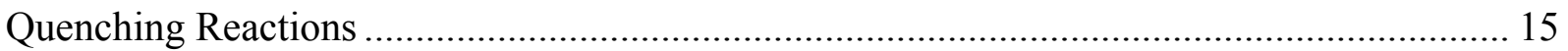

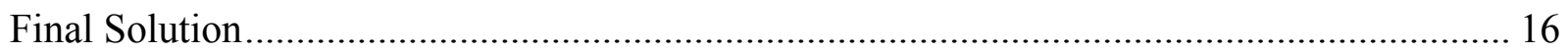

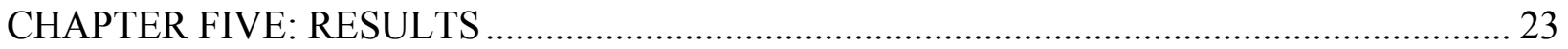

CHAPTER SIX: SAMPLE APPLICATION: ETHANE OXIDATION …........................................ 31

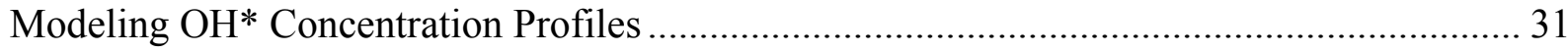

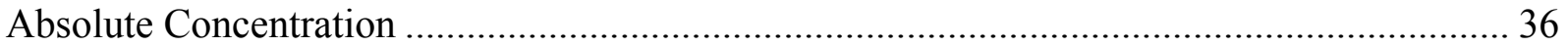

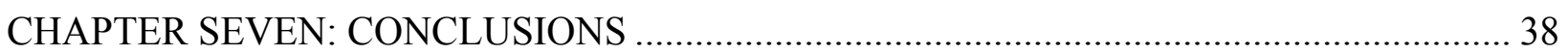

APPENDIX A: RATE COEFFICIENTS AND ARRHENIUS KINETICS ................................. 39

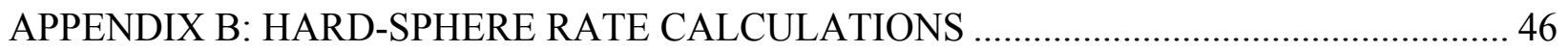


APPENDIX C: SPECIES IN THE DETAILED MODEL ............................................... 50

APPENDIX D: REACTIONS IN THE DETAILED MODEL …........................................... 53

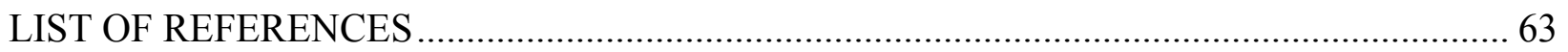




\section{LIST OF FIGURES}

Figure 1. Maximum $\mathrm{OH}^{*}$ concentration as a function of temperature at constant pressure and optical settings. This parameter sets the value of $\mathrm{E}_{1}$ for a given $\mathrm{k}_{1}{ }^{\circ}$. Curves were calculated assuming a reference rate of $\mathrm{k}_{1}{ }^{\mathrm{o}}=1.3 \times 10^{13} \mathrm{~cm}^{6} \mathrm{~mol}^{-1} \mathrm{~s}^{-1}$. 10

Figure 2. Functional dependence of $\mathrm{E}_{1}$ on $\mathrm{k}_{1}{ }^{0}$ The routine converges for $8 \times 10^{11}<\mathrm{k}_{1}{ }^{0}<1.4 \times 10^{13}$ $\mathrm{cm}^{6} \mathrm{~mol}^{-2} \mathrm{~s}^{-1}$. The final value of $\mathrm{E}_{1}=10 \mathrm{kcal} / \mathrm{mol}$ lies within the range of convergence. The relationship was deduced from experiments with Mixtures 1 and 2. $\left(\mathrm{H}_{2} / \mathrm{O}_{2} / \mathrm{Ar}, \phi=1.0\right) \ldots .11$

Figure 3. Sample calibration curves assuming two typical values of the reference rate, $\mathrm{k}_{1}{ }^{\mathrm{o}}$. $\left[\mathrm{OH}^{*}\right]_{\max }(\mathrm{V})$ was then calculated from curve fits for various values of $\mathrm{k}_{1}{ }^{\circ}$. The factor-offive variation in the rate of $\mathrm{H}+\mathrm{OH}+\mathrm{OH}(\mathrm{R} 2)$ shows that the calibration is not sensitive to $\mathrm{k}_{2}$. This example is from Mixture 3 data, $\mathrm{P}_{\mathrm{avg}}=1.6 \mathrm{~atm}$. 13

Figure 4. Rate of the $\mathrm{CH}+\mathrm{O}_{2}$ formation step $\left(\mathrm{k}_{0}\right)$ calculated for two typical values of $\mathrm{k}_{1}{ }^{\circ}$, across a range of temperatures. Error bars determined from maximum scatter indicate an uncertainty of a factor of three, to be reduced with subsequent calculations. Data are from Mixture 5, $\mathrm{P}_{\mathrm{avg}}=0.96 \mathrm{~atm}$ 14

Figure 5. Functional dependence of $\mathrm{k}_{0}$ on $\mathrm{k}_{1}{ }^{0}$. The routine converges for $8 \times 10^{11}<\mathrm{k}_{1}{ }^{0}<$ $1.4 \times 10^{13} \mathrm{~cm}^{6} \mathrm{~mol}^{-2} \mathrm{~s}^{-1}$. The final value of $\mathrm{k}_{0}=6.0 \times 10^{12} \mathrm{~cm}^{3} \mathrm{~mol}^{-1} \mathrm{~s}^{-1}$ (at $1490 \mathrm{~K}$ ) lies within the range of convergence, in a region of the curve where $\mathrm{k}_{0}$ is highly sensitive to $\mathrm{k}_{1}{ }^{\circ}$. 15

Figure 6. $\mathrm{OH}^{*}$ profile illustrating the contribution of each formation reaction as a function of time. The early portion of the profile ( $\mathrm{t}<275 \mu \mathrm{s})$ is due to $\mathrm{CH}+\mathrm{O}_{2}(\mathrm{R} 0)$ and the later portion ( $\mathrm{t}>275 \mu \mathrm{s})$ is due to $\mathrm{H}+\mathrm{O}+\mathrm{M}$ and $\mathrm{H}+2 \mathrm{OH}(\mathrm{R} 1,2)$. Mixture 9, $1665 \mathrm{~K}, 1.26 \mathrm{~atm}$. The ratio between the two peaks is very sensitive to the solution set, as can be seen from the 
curves calculated assuming a 10\% increase and decrease in the value of the reference rate.

Figure 7. Typical experimental profiles from mixture $4, \mathrm{H}_{2} / \mathrm{CH}_{4}=80$, at pressures near 1.2 atm. All profiles have been normalized to their peak values. 18

Figure 8. Typical experimental profiles from Mixture $9, \mathrm{H}_{2} / \mathrm{CH}_{4}=340$, at pressures near 1.1 atm. All profiles have been normalized to their peak values. The $1665-\mathrm{K}$ curve corresponds to the conditions of Fig. 6 . 19

Figure 9. Solution set uniquely determined from a high-temperature experiment. Mixture 9, $\mathrm{H}_{2} / \mathrm{CH}_{4}=340,1.17 \mathrm{~atm}, 1925 \mathrm{~K}$. At these conditions, the H-atom peak is approximately $50 \%$ of the $\mathrm{CH}$ peak. 20

Figure 10. Solution set uniquely determined from a mid-temperature experiment. Mixture 9, $\mathrm{H}_{2} / \mathrm{CH}_{4}=340,1.24 \mathrm{~atm}, 1468 \mathrm{~K}$. At these conditions, the H-atom peak is approximately 1.1 times greater than the $\mathrm{CH}$ peak. 21

Figure 11. Solution set uniquely determined from a low-temperature experiment. Mixture 8, $\mathrm{H}_{2} / \mathrm{CH}_{4}=80,1.36$, atm, $1164 \mathrm{~K}$. At these conditions, the two peaks are difficult to identify, but the shape of the profile is sensitive to the solution set...... 22

Figure 12. Data points and curve fit for the rate of $\mathrm{CH}+\mathrm{O}_{2}\left(\mathrm{k}_{0}\right)$. Previous high-temperature measurements by Porter et al. [26] and Smith et al. [14] are shown for comparison. The current results should be used rather than the earlier recommendation by Hall and Petersen [36]. 24

Figure 13. Rate expression derived herein for $\mathrm{H}+\mathrm{O}+\mathrm{M}\left(\mathrm{k}_{1}\right)$. Previous measurements by Hidaka et al. [19], Koike and Morinaga [20], and Smith et al. [15] are shown for 
comparison. The current results should be used rather than the earlier recommendation by Petersen et al. [37]

Figure 14. Rate expressions for $\mathrm{H}+\mathrm{OH}+\mathrm{OH}\left(\mathrm{k}_{2}\right)$ available in the literature. The most recent value of Smith et al. [15] was used in this work and not altered. Sensitivity analyses indicated that the fitting parameters employed are sensitive only to the presence of this reaction, not its rate. Citations are Hollander [12], Kaskan [9], Davis et al. [13], Smith et al. [15], Zeegers and Alkemade [10] and Hidaka et al. [19] 27

Figure 15. Effect of uncertainties in the individual rate coefficients. Quenching rates have been varied by a factor of ten, as has the rate of $\mathrm{H}+\mathrm{OH}+\mathrm{OH}\left(\mathrm{k}_{2}\right)$. The important formation rates $\left(\mathrm{k}_{0}\right.$ and $\left.\mathrm{k}_{1}\right)$ have been increased by a factor of two. Quenching with argon (R3) and formation through $\mathrm{H}+\mathrm{OH}+\mathrm{OH}$ (R2) have a negligible effect on the profile while quenching with water (R4) introduces uncertainty comparable to a factor-of-two uncertainty in $\mathrm{k}_{0}$. 28

Figure 16. Effect of order-of-magnitude uncertainties in the quenching rates on the calculated profiles. Quenching with argon (R3) has a negligible effect on the measured parameters while quenching with water (R4) introduces uncertainty comparable to a factor-of-two uncertainty in the solution set.

Figure 17. The present model evaluated relative to other models available in the literature. The model by Smith et al. [15] includes all three formation reactions ( $\mathrm{R} 0-\mathrm{R} 2)$, that of Porter et al. [26] includes only R0 and quenching steps. The earlier work by the authors did not include $\mathrm{R} 2$, but has a $\mathrm{k}_{1} / \mathrm{k}_{0}$ ratio similar to that of the present work..... 30

Figure 18. Typical $\mathrm{OH}^{*}$ profile for a low-temperature fuel-lean experiment. Both models show the rapid rise and fall of $\left[\mathrm{OH}^{*}\right]$ around ignition time, while only the San Diego Mechanism 
[41,42] shows the post-ignition duration. The verification model was assembled to verify that the reactions identified in the text affect the shape of the curve. 32

Figure 19. Rate of $\mathrm{CH}$ production at the conditions of Fig. 18. The five reactions shown make the largest contribution to $\mathrm{CH}$ concentration at the peak time. The shape of the $\mathrm{OH}^{*}$ profile provides information about the $\mathrm{CH}$ chemistry because $\mathrm{CH}$ is its primary precursor near ignition time. 34

Figure 20. Typical experimental profile from a high-temperature fuel-rich experiment. Both models predict the important features of the curve at the conditions shown, especially the pre-ignition rise in $\left[\mathrm{OH}^{*}\right]$. 35

Figure 21. Absolute $\mathrm{OH}^{*}$ concentrations from calibrated experiments. Both models predict the $\left[\mathrm{OH}^{*}\right]$ within an order of magnitude, with the San Diego Mechanism [41,42] matching the magnitude more closely, and the Wang and Laskin model [40] matching the slope. A verification model was assembled using updated $\mathrm{CH}$ formation rates from GRI-Mech 3.0 [35] showing that the identified steps do affect the $\mathrm{OH}^{*}$ concentration. This plot demonstrates the use of the new model in a calibration to measure absolute concentration of $\mathrm{OH}^{*}$. 


\section{LIST OF TABLES}

Table 1. Elementary reactions to model $\mathrm{OH}^{*}$ formation and quenching. Rate coefficients are

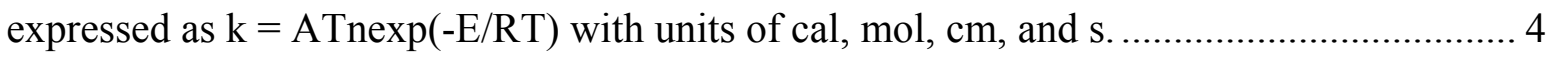

Table 2. Experimental mixtures and mole fractions (\%) with associated fitting parameters....... 7

Table 3. Example mechanism. Selected rates are taken from the GRI-Mech 3.0 [35] methane mechanim. Collision efficiencies for third-body reactions have been omitted for clarity.... 41 


\section{LIST OF ACRONYMS/ABBREVIATIONS}

$\begin{array}{ll}\mathrm{OH}^{*} & \text { electronically excited hydroxyl radical } \\ \mathrm{OH}(\mathrm{X}) & \text { ground-state hydroxyl radical } \\ \phi & \text { fuel/oxidizer equivalence ratio } \\ \mathrm{CH}_{4} & \text { methane } \\ \mathrm{H}_{2} & \text { molecular hydrogen } \\ \mathrm{T}_{5} & \text { experimental temperature }(\mathrm{K}) \\ \mathrm{P}_{5} & \text { experimental pressure (atm) } \\ \mathrm{k}_{\mathrm{i}} & \text { rate coefficient of the } \mathrm{i}^{\text {th }} \text { elementary reaction (for the forward reaction, as written) } \\ \mathrm{k}_{\mathrm{i}, \mathrm{R}} & \text { rate coefficient of the } \mathrm{i}^{\text {th }} \text { elementary reaction in the reverse direction } \\ \mathrm{Ri} & \text { number of the } \mathrm{i}^{\text {th }} \text { elementary reaction } \\ \mathrm{A} & \text { pre-exponential factor in the Arrhenius expression for a rate coefficient } \\ \mathrm{n} & \text { temperature exponent in the Arrhenius expression } \\ \mathrm{E} & \text { activation energy of the elementary reaction (cal/mol) } \\ \mathrm{R} & \text { universal gas constant } \\ {[\mathrm{X}]} & \text { concentration of species } \mathrm{X} \\ \mathrm{t} & \text { experimental time ( } \mu \text { s) } \\ \mathrm{m} & \text { mass of species } \mathrm{X}(\mathrm{kg})\end{array}$




\section{CHAPTER ONE: INTRODUCTION}

Chemiluminescence from the electronically excited hydroxyl radical, $\mathrm{OH}^{*}$, due to the $\mathrm{OH}\left(\mathrm{A}^{2} \Sigma^{+} \rightarrow \mathrm{X}^{2} \Pi\right)$ transition is a frequently used diagnostic in combustion research. Emission near its characteristic wavelength of $307 \mathrm{~nm}$ provides a convenient, non-intrusive measure of transient combustion phenomena that is efficient in cost and space consumption. Higgins et al. [1] demonstrated the utility of $\mathrm{OH}^{*}$ emission measurements in laminar pre-mixed flames. $\mathrm{OH}$ chemiluminescence has been used to mark ignition times in the $\mathrm{H}_{2} / \mathrm{O}_{2}$ system by Asaba et al. [2] and in shock-tube studies of hydrocarbon oxidation by Seery and Bowman [3] and Petersen et al. [4] to name but a few. Muruganandam et al. [5] and Hardalupas and Orain [6] have used the $\mathrm{OH}^{*} / \mathrm{CH}^{*}$ ratio to diagnose equivalence ratio in reacting systems. The use of chemiluminescence techniques has become an area of active research due primarily to two factors. Their nonintrusive nature provides an indication of the progress of a combustion reaction, and their relatively low cost and space consumption make them ideal for many applications. The equipment necessary to perform such measurements can be light-weight and portable which is important for measurements made in space. Chemiluminescent imaging of flame structure and growth in micro-gravity environments is an example of such an application. Because the light source is the combustion reaction itself, no external light source such as a laser or bulb is necessary; this translates to a significant reduction in payload requirements. In reacting-flow fields such as those encountered in gas-turbine combustors, the distribution of light intensity can be correlated to other parameters such as temperature distribution or heat release and degree of reaction or mixing. 
However, unlike more sophisticated absorption techniques, there is no elementary relationship between recorded intensity and absolute concentration of the emitting species. Hence, emission spectroscopy lacks the utility of a quantitative diagnostic. Calibration can still be accomplished using detailed kinetics modeling if the $\mathrm{OH}^{*}$ kinetics are known with suitable accuracy. In addition to a detailed mechanism to predict the ground-state chemistry, such a calibration requires knowledge of the elementary reactions that form and quench the excited state and of their respective rate coefficients. Previous studies have identified the relevant reactions, yet discrepancies remain concerning their rates, and hence their relative importance.

Early suggestions for the reactions forming $\mathrm{OH}^{*}$ were offered by Gaydon $[7,8]$. These original works focused primarily on identification of the formation reactions, without regard for the reaction rates. Since that time, several flame studies of $\mathrm{OH}(\mathrm{A} \rightarrow \mathrm{X})$ chemiluminescence in the $\mathrm{H}_{2} / \mathrm{O}_{2}$ reaction have been conducted [8-15] including the early works of Charton and Gaydon [8] and Kaskan [9] and recent work by Smith et al. [14,15]. Smith et al. [14] were the first to present a comprehensive $\mathrm{OH}^{*}$ model employing a detailed mechanism with a full set of $\mathrm{OH}^{*}$ reactions and rates. The predictions of that model will be considered relative to the results of this study. $\mathrm{OH}^{*}$ emission from hydrogen mixtures has been studied in shock tubes by Belles and Lauver [16], Gutman et al. [17], Gardiner et al. [18], Hidaka et al. [19], Koike and Morinaga [20], and Paul et al. [21]. Measurements of $\mathrm{OH}^{*}$ formation rates in hydrocarbon mixtures have been reported by Carl et al. [22], Grebe and Homann [23], Lichtin et al. [24,25], Smith et al. [14,15], and Porter et al. [26]. The more recent measurements by Carl et al. [22] were conducted at room temperature, while the shock-tube experiments were all at higher temperatures, comparable of those of this work. Theoretical studies of the collisional quenching of $\mathrm{OH}^{*}$ are available as well [27-30]. Because collisional quenching of the excited state is an energetic process rather than a 
chemical process, the theoretical calculation of the quenching rates is well defined, and literature values of the quenching rates was sufficient to complete the new model derived herein, with experiments focusing on the formation rates only.

The above literature sources have come to the conclusion that the primary $\mathrm{OH}^{*}$ formation reaction in hydrocarbon combustion processes is

$$
\mathrm{CH}+\mathrm{O}_{2} \leftrightarrows \mathrm{OH}^{*}+\mathrm{CO}
$$

but they differ in their recommendations for $\mathrm{OH}^{*}$ formation in hydrogen mixtures with some favoring

$$
\mathrm{H}+\mathrm{O}+\mathrm{M} \leftrightarrows \mathrm{OH}^{*}+\mathrm{M}
$$

while others support

$$
\mathrm{H}+\mathrm{OH}+\mathrm{OH} \leftrightarrows \mathrm{OH}^{*}+\mathrm{H}_{2} \mathrm{O}
$$

$\mathrm{OH}^{*}$ quenching occurs primarily via

$$
\begin{gathered}
\mathrm{OH}^{*}+\mathrm{Ar} \leftrightarrows \mathrm{OH}+\mathrm{Ar} \\
\mathrm{OH}^{*}+\mathrm{H}_{2} \mathrm{O} \leftrightarrows \mathrm{OH}+\mathrm{H}_{2} \mathrm{O}
\end{gathered}
$$

and generally by

$$
\mathrm{OH}^{*}+\mathrm{M} \leftrightarrows \mathrm{OH}+\mathrm{M}
$$

Table 1 shows all the important $\mathrm{OH}^{*}$ formation and quenching reactions along with their respective rate parameters and sources. A review of the significance of a rate coefficient (or 
simply a rate) is given in Appendix A. Literature values were used for all quenching rates, while the rates of the key formation steps, R0 and R1 were derived in this work. Based on the recent suggestions of Smith et al. [15], all 3 candidate formation steps (R0 - R2) have been included, with their rates to be determined. This paper begins with an overview of the experimental facility and procedure used to obtain $\mathrm{OH}^{*}$ emission measurements. Then the kinetics modeling approach to data interpretation is described, with emphasis on the process used to resolve discrepancies concerning the $\mathrm{OH}^{*}$ kinetics and ultimately to quantify the emission diagnostic. After derivation of the new model, an example is given of the application of the calibration technique to a practical problem from a recent ethane oxidation study.

Table 1. Elementary reactions to model $\mathrm{OH}^{*}$ formation and quenching. Rate coefficients are expressed as $\mathrm{k}=\mathrm{AT}^{\mathrm{n}} \exp (-\mathrm{E} / \mathrm{RT})$ with units of cal, mol, $\mathrm{cm}$, and $\mathrm{s}$.

\begin{tabular}{lllllll}
\hline$\#$ & Reaction & $\mathrm{A}$ & $\mathrm{n}$ & $\mathrm{E}$ & Source & Ref\# \\
\hline 0 & $\mathrm{CH}+\mathrm{O}_{2} \leftrightarrows \mathrm{OH}^{*}+\mathrm{CO}$ & $4.80 \times 10^{16}$ & -1 & 5100 & this work & \\
1 & $\mathrm{H}+\mathrm{O}+\mathrm{M} \leftrightarrows \mathrm{OH}^{*}+\mathrm{M}$ & $3.80 \times 10^{14}$ & 0.0 & 10,000 & this work & \\
2 & $\mathrm{H}+\mathrm{OH}+\mathrm{OH} \leftrightarrows \mathrm{OH}^{*}+\mathrm{H}_{2} \mathrm{O}$ & $1.45 \times 10^{15}$ & 0.0 & 0.0 & Smith et al. & 15 \\
3 & $\mathrm{OH}^{*}+\mathrm{Ar} \leftrightarrows \mathrm{OH}+\mathrm{Ar}$ & $2.17 \times 10^{10}$ & 0.5 & 2060 & Paul et al. & 21 \\
4 & $\mathrm{OH}^{*}+\mathrm{H}_{2} \mathrm{O} \leftrightarrows \mathrm{OH}+\mathrm{H}_{2} \mathrm{O}$ & $5.92 \times 10^{12}$ & 0.5 & -861 & Tamura et al. & 30 \\
5 & $\mathrm{OH}^{*}+\mathrm{CO} \leftrightarrows \mathrm{OH}+\mathrm{CO}_{2}$ & $2.75 \times 10^{12}$ & 0.5 & -968 & Tamura et al. & 30 \\
6 & $\mathrm{OH}^{*}+\mathrm{CO} \leftrightarrows \mathrm{OH}+\mathrm{CO}_{7}$ & $3.23 \times 10^{12}$ & 0.5 & -787 & Tamura et al. & 30 \\
7 & $\mathrm{OH}^{*}+\mathrm{H} 5 \mathrm{OH}+\mathrm{H}_{2}$ & $2.95 \times 10^{12}$ & 0.5 & -444 & Tamura et al. & 30 \\
8 & $\mathrm{OH}^{*}+\mathrm{O}_{2} \leftrightarrows \mathrm{OH}+\mathrm{O}_{2}$ & $2.10 \times 10^{12}$ & 0.5 & -482 & Tamura et al. & 30 \\
9 & $\mathrm{OH}^{*}+\mathrm{OH} \leftrightarrows \mathrm{OH}+\mathrm{OH}_{10}$ & $1.50 \times 10^{12}$ & 0.5 & 0.0 & Hidaka et al. & 19 \\
10 & $\mathrm{OH}^{*}+\mathrm{H} \leftrightarrows \mathrm{OH}+\mathrm{H}$ & $1.50 \times 10^{12}$ & 0.5 & 0.0 & Hidaka et al. & 19 \\
11 & $\mathrm{OH}^{*}+\mathrm{O} \leftrightarrows \mathrm{OH}+\mathrm{O}$ & $1.50 \times 10^{12}$ & 0.5 & 0.0 & Hidaka et al. & 19 \\
12 & $\mathrm{OH}^{*}+\mathrm{CH} \leftrightarrows \mathrm{OH}+\mathrm{CH}_{4}$ & $3.36 \times 10^{12}$ & 0.5 & -635 & Tamura et al. & 30 \\
13 & $\mathrm{OH}^{*} \leftrightarrows \mathrm{OH}+\mathrm{h} v$ & $1.40 \times 10^{6}$ & 0.0 & 0.0 & Hidaka et al. & 19 \\
\hline
\end{tabular}

The value for quenching by Ar was reported by Paul et al. ${ }^{21}$ as an upper limit, and is used herein as the nominal value for this rate. 


\section{CHAPTER TWO: EXPERIMENT}

Experimental data were obtained in a shock-tube facility described previously in detail by Petersen et al. [31,32]. $\mathrm{OH}^{*}$ emission profiles were recorded from the sidewall of a stainless steel shock tube. After escaping from a $\mathrm{CaF}_{2}$ window located $1.6 \mathrm{~cm}$ from the endwall, light from the $\mathrm{OH}$ chemiluminescence passed through a slit and a narrow-band filter (centered at $310 \mathrm{~nm}$ ) and was focused onto a Hamamatsu 1P21 photomultiplier tube (PMT). This signal was relayed to a computer-based data acquisition system with two CS512 computer oscilloscope boards from Gage Applied Sciences, giving a total of four channels at a speed of $5 \mathrm{MHz}$ per channel with 12bit resolution. The width of the slit-approximately $1 \mathrm{~mm}$-was selected to provide an optimal balance between strength and resolution of the recorded signal. The PMT had been previously optimized [31] to maintain linearity of output voltage with respect to input signal; all experiments were performed at conditions selected to produce peak voltages within the range of PMT linearity. To enable comparison amongst the recorded $\mathrm{OH}^{*}$ profiles, identical optical settings were maintained throughout a series of experiments. Care was taken to ensure that the optical equipment was not disturbed.

The incident shock wave was monitored with five, fast-response (less than $1 \mu \mathrm{s}$ ) PCB P113A pressure transducers and four Fluke model PM6666 time-interval counters with which its velocity was measured. Based on that measurement, reflected-shock test properties (i.e. $\mathrm{P}_{5}$ and $\mathrm{T}_{5}$ ) were calculated using the standard 1-D shock-tube relations and the Sandia thermodynamic database [33]. The uncertainty of the reflected-shock temperature has been estimated to be approximately $5 \mathrm{~K}$ [31]. A fast-response pressure transducer located opposite the optical port determined the time of the reflected-shock passage (and hence $t=0$ for the experiment). 
The driver tube is $3.5 \mathrm{~m}$ long with a $7.62-\mathrm{cm}$ inner diameter, and the driven tube is 10.7 $\mathrm{m}$ long with a $16.2-\mathrm{cm}$ inner diameter. For typical experiments in this facility, with argon as the bath gas and helium as the driver gas, the shock tube creates a constant-property test time of approximately $3 \mathrm{~ms}$, as used for most of the experiments of this study. To perform certain experiments at lower temperatures $(\mathrm{T}<1400 \mathrm{~K})$, the driver gas was tailored with $\mathrm{He} / \mathrm{CO}_{2}$ blends to generate longer test times (on the order of $10 \mathrm{~ms}$ ) using the procedures of Amadio et al. [34].

Test mixtures were prepared manometrically from ultra-high purity (UHP) argon, research-grade methane, high-purity hydrogen, and UHP oxygen. Dilution levels were maintained at approximately $99 \%$ Ar to minimize heat release and pressure rise due to combustion. Argon dilution serves as a pressure and heat sink to maintain constant pressure and constant temperature test conditions so that these variables can be accurately characterized in the model. For certain calibration mixtures, larger fuel concentrations (lower levels of dilution) were necessary to produce the desired $\mathrm{OH}^{*}$ yield. However, only peal concentrations were taken from these experiments. Calculations showed that the time of peak $\mathrm{OH}^{*}$ occurred early in the reaction, well before the time of significant heat release. To better characterize the rise in pressure and temperature from these experiments, calculations were performed assuming constant volume (rather than constant pressure).

Table 2 shows the composition of all test mixtures. The driven section was evacuated to below $10^{-5}$ torr prior to each experiment, and this facility's leaking and out-gassing rate is approximately $10^{-4}$ torr/min [31]. For the purposes of this study, methane was included in the mixtures as a source of $\mathrm{CH}$ radicals, thus care was taken to prevent contamination from any other C-containing compounds. The two fuels $\left(\mathrm{H}_{2}\right.$ and $\left.\mathrm{CH}_{4}\right)$ were chosen because their chemistry is well known. At the conditions of this study, the detailed chemistry of hydrogen and methane 
oxidation can be predicted accurately, so that the additional $\mathrm{OH}^{*}$ reactions could be isolated. Composition of the mixtures (per table 2) was then selected based on preliminary calculations to provide optimal sensitivity of the measured parameter to the respective target.

Table 2. Experimental mixtures and mole fractions (\%) with associated fitting parameters.

\begin{tabular}{|c|c|c|c|c|c|c|c|}
\hline Mixture \# & $\% \mathrm{H}_{2}$ & $\% \mathrm{O}_{2}$ & $\% \mathrm{CH}_{4}$ & $\% \mathrm{Ar}$ & $\mathrm{H}_{2} / \mathrm{CH}_{4}$ & target & parameter \\
\hline 1 & 0.60 & 0.30 & -- & 99.10 & -- & $\mathrm{E}_{1}\left(\mathrm{k}_{1}^{\mathrm{o}}\right)$ & {$\left[\mathrm{OH}^{*}\right]_{\max }(\mathrm{T})$} \\
\hline 2 & 1.00 & 0.50 & -- & 98.50 & -- & $\mathrm{E}_{1}\left(\mathrm{k}_{1}{ }^{\mathrm{o}}\right)$ & {$\left[\mathrm{OH}^{*}\right]_{\max }(\mathrm{T})$} \\
\hline 3 & 4.22 & 2.11 & -- & 93.67 & -- & $\mathrm{k}_{0}\left(\mathrm{k}_{1}{ }^{\mathrm{o}}\right)$ & calibrate mix 5 \\
\hline 4 & 3.32 & 1.65 & -- & 95.03 & -- & $\mathrm{k}_{0}\left(\mathrm{k}_{1}^{\mathrm{o}}\right)$ & calibrate mix 6 \\
\hline 5 & 0.20 & 0.30 & 0.10 & 99.40 & 2.0 & $\mathrm{k}_{0}\left(\mathrm{k}_{1}^{\mathrm{o}}\right)$ & calibrated $\left[\mathrm{OH}^{*}\right]$ \\
\hline 6 & 0.26 & 0.42 & 0.12 & 99.20 & 2.2 & $\mathrm{k}_{0}\left(\mathrm{k}_{1}^{\mathrm{o}}\right)$ & calibrated $\left[\mathrm{OH}^{*}\right]$ \\
\hline 7 & -- & 0.06 & 0.03 & 99.91 & 0.0 & $\mathrm{k}_{0}\left(\mathrm{k}_{1}^{\mathrm{o}}\right)$ & calibrated $\left[\mathrm{OH}^{*}\right]$ \\
\hline 8 & 0.80 & 0.42 & 0.01 & 98.77 & 80.0 & solution & ratio of two peaks \\
\hline 9 & 0.633 & 0.320 & 0.00187 & 99.05 & 338.5 & solution & ratio of two peaks \\
\hline
\end{tabular}




\section{CHAPTER THREE: MODELING APPROACH}

Based on the literature cited above, it is reasonable to assume that the possible and likely formation reactions $(\mathrm{R} 0-\mathrm{R} 2)$ are known; optimization of the $\mathrm{OH}^{*}$ kinetics model requires an accurate determination of the corresponding rate coefficients $\left(\mathrm{k}_{0}-\mathrm{k}_{2}\right)$. In this work, the approach taken to find these rates can be summarized as follows. The hydrogen/oxygen reactions $(\mathrm{R} 1,2)$ were isolated and R0 eliminated by performing experiments in $\mathrm{H}_{2} / \mathrm{O}_{2}$ mixtures with constant optical settings. The shape of the $\left[\mathrm{OH}^{*}\right]_{\max }(\mathrm{T})$ curve was used to target the temperature dependence of the rate of formation through $\mathrm{H}+\mathrm{O}+\mathrm{M}\left(\mathrm{E}_{1}\right)$. Specifically, this parameter was used to determine the functional relationship of $\mathrm{E}_{1}$ on $\mathrm{k}_{1}$, at a reference temperature, i.e. $\mathrm{E}_{1}\left(\mathrm{k}_{1}{ }^{\mathrm{o}}\right)$.

With $\mathrm{E}_{1}\left(\mathrm{k}_{1}{ }^{\mathrm{o}}\right)$ known, $\mathrm{k}_{0}\left(\mathrm{k}_{1}\right)$ was found from $\mathrm{H}_{2}$-based mixtures and $\mathrm{CH}_{4}$-based mixtures maintaining constant optical settings for both. The measured parameters were found to be insensitive to R2, so that its rate was left at the reference value. Finally, with the key formation rates specified as functions of $\mathrm{k}_{1}{ }^{\mathrm{o}}$, the shape of the $\left[\mathrm{OH}^{*}\right](\mathrm{t})$ curve was used to uniquely determine the value of all three parameters $\left(\mathrm{k}_{0}, \mathrm{E}_{1}, \mathrm{k}_{1}{ }^{\mathrm{o}}\right)$.

Kinetics calculations were performed with the chemkin collection software using the shock and senkin routines. The detailed $\mathrm{CH}_{4}$ and $\mathrm{H}_{2}$ chemistry was modeled with the Gas Research Institute's GRI-Mech 3.0 [35] methane mechanism that has been optimized and validated for the conditions of this work. The complete set of compounds and reactions contained in GRI-Mech 3.0 are given in appendix C and D, respectively. 


\section{CHAPTER FOUR: FITTING ROUTINE}

\section{Activation Energy of R1}

The first fitting parameter employed was the functional dependence of peak $\mathrm{OH}^{*}$ concentration on ordinary temperature for $\mathrm{H}_{2} / \mathrm{O}_{2} / \mathrm{Ar}$ mixtures. Such test mixtures eliminated $\mathrm{R} 0$ entirely, and minimized sensitivity to R2. Thus, at these conditions, R1 is the dominant formation step. However, only one fitting parameter was used, while two unknowns remain; the magnitude and slope of the $\mathrm{k}_{1}(\mathrm{~T})$ curve, i.e. $\mathrm{A}_{1}$ and $\mathrm{E}_{1}$. Since neither $\mathrm{A}_{1}$ nor $\mathrm{E}_{1}$ can be determined uniquely from a single fitting parameter, the functional dependence of $E_{1}$ on the magnitude of $k_{1}$ was first established, reserving unique determination for a later step in the optimization process. For consistency, $1490 \mathrm{~K}$ was taken as a reference temperature, (denoted by a superscripted "zero") and all data were normalized accordingly.

Figure 1 shows the $\left[\mathrm{OH}^{*}\right]_{\max }(\mathrm{T})$ curve found for mixture 1. At these conditions, the maximum concentration is nearly constant with respect to temperature, peaking near $1600 \mathrm{~K}$ and then decreasing slightly with temperature. All points have been normalized by the value at 1490 $\mathrm{K}$ for comparison to the mechanism and adjusted to the average experimental pressure of 0.96 atm. Such curves were calculated for various values of the rate of $\mathrm{H}+\mathrm{O}+\mathrm{M}$ at $1490 \mathrm{~K}\left(\mathrm{k}_{1}{ }^{\circ}\right)$ so that for each value of $\mathrm{k}_{1}{ }^{\mathrm{o}}$, a unique value for the corresponding activation energy, $\mathrm{E}_{1}$, could be calculated. This parameter provides neither the magnitude of $\mathrm{k}_{1}{ }^{0}$ nor of $\mathrm{E}_{1}$, but simply the relationship between the two. For comparison, the effects of variations in the rate of $\mathrm{H}+\mathrm{OH}+$ OH (R2) are shown as well. Two additional curves are shown, the first calculated assuming an order-of-magnitude increase in $\mathrm{k}_{2}$, and the second calculated assigning an activation energy, $\mathrm{E}_{2}$, 
of $20 \mathrm{kcal} / \mathrm{mol}$. Neither of these variations significantly affects the calculated curve, indicating that this parameter is not sensitive to R2. As $\mathrm{k}_{2}$ decreases, so does the effect of this reaction, so that the greater sensitivity is seen with increasing $\mathrm{k}_{2}$. In Fig. 1 , the best fit is found for $\mathrm{E}_{1}=10$ $\mathrm{kcal} / \mathrm{mol}$, the sensitivity of the fitting parameter to this activation energy is demonstrated by the curves above and below the data, calculated assuming and activation energy of $\mathrm{E}_{1}=20 \mathrm{kcal} / \mathrm{mol}$ and $\mathrm{E}_{1}=5 \mathrm{kcal} / \mathrm{mol}$, respectively.

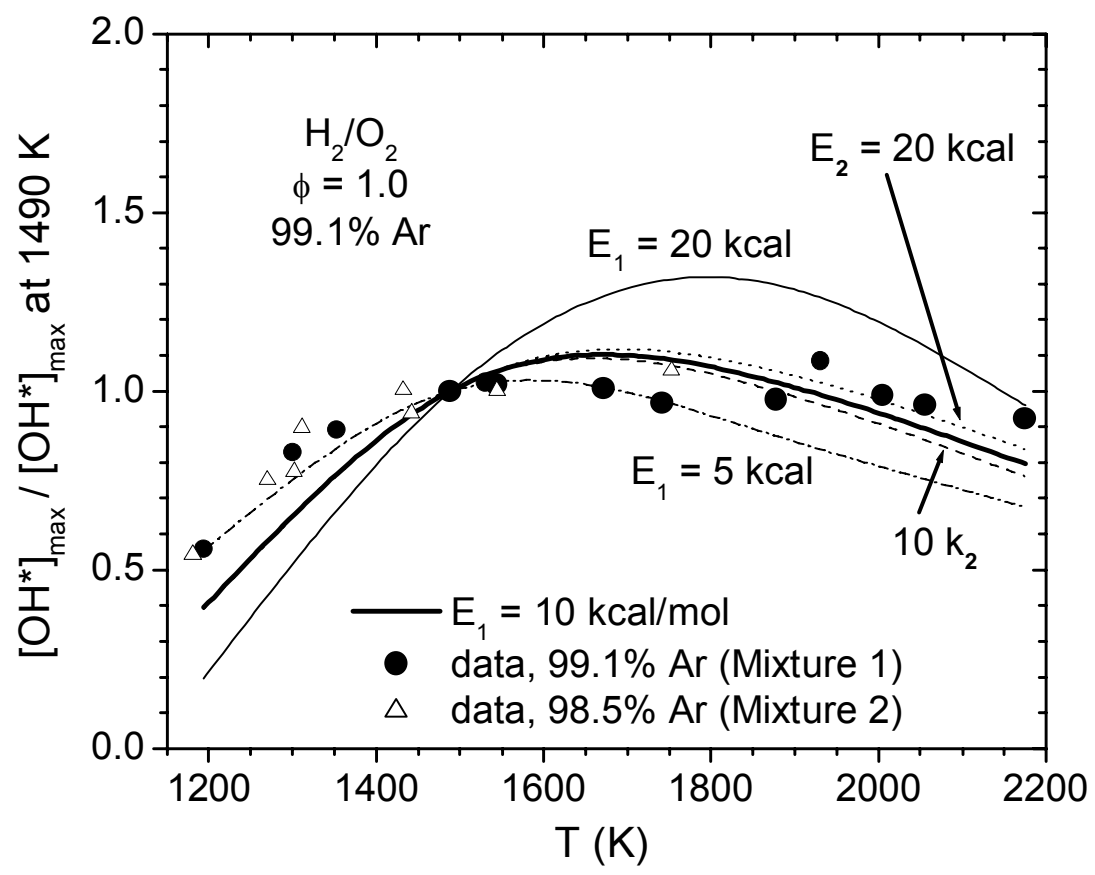

Figure 1. Maximum $\mathrm{OH}^{*}$ concentration as a function of temperature at constant pressure and optical settings. This parameter sets the value of $\mathrm{E}_{1}$ for a given $\mathrm{k}_{1}{ }^{\circ}$. Curves were calculated assuming a reference rate of $\mathrm{k}_{1}{ }^{\mathrm{o}}=1.3 \times 10^{13} \mathrm{~cm}^{6} \mathrm{~mol}^{-1} \mathrm{~s}^{-1}$. 
Additional data from Mixture $2(98.5 \%$ Ar) are shown in Fig. 1 as well. Dilution level showed no significant effect on the fitting parameter, either in the data or the model.

Multiple calculations were performed in the manner shown in Fig. 1 generating values of $\mathrm{E}_{1}\left(\mathrm{k}_{1}{ }^{\mathrm{o}}\right)$; Fig 2 shows the resulting curve. The fitting routine converges for $8 \times 10^{11}<\mathrm{k}_{1}{ }^{0}<$ $1.4 \times 10^{13} \mathrm{~cm}^{6} \mathrm{~mol}^{-2} \mathrm{~s}^{-1}$. For reference rates outside of that range, no value of $\mathrm{E}_{1}$ will fit the data. The process ultimately converges to a value within the allowable range $\left(E_{1}=10 \mathrm{kcal} / \mathrm{mol}\right)$ via the fitting routine to be described in the following paragraphs.

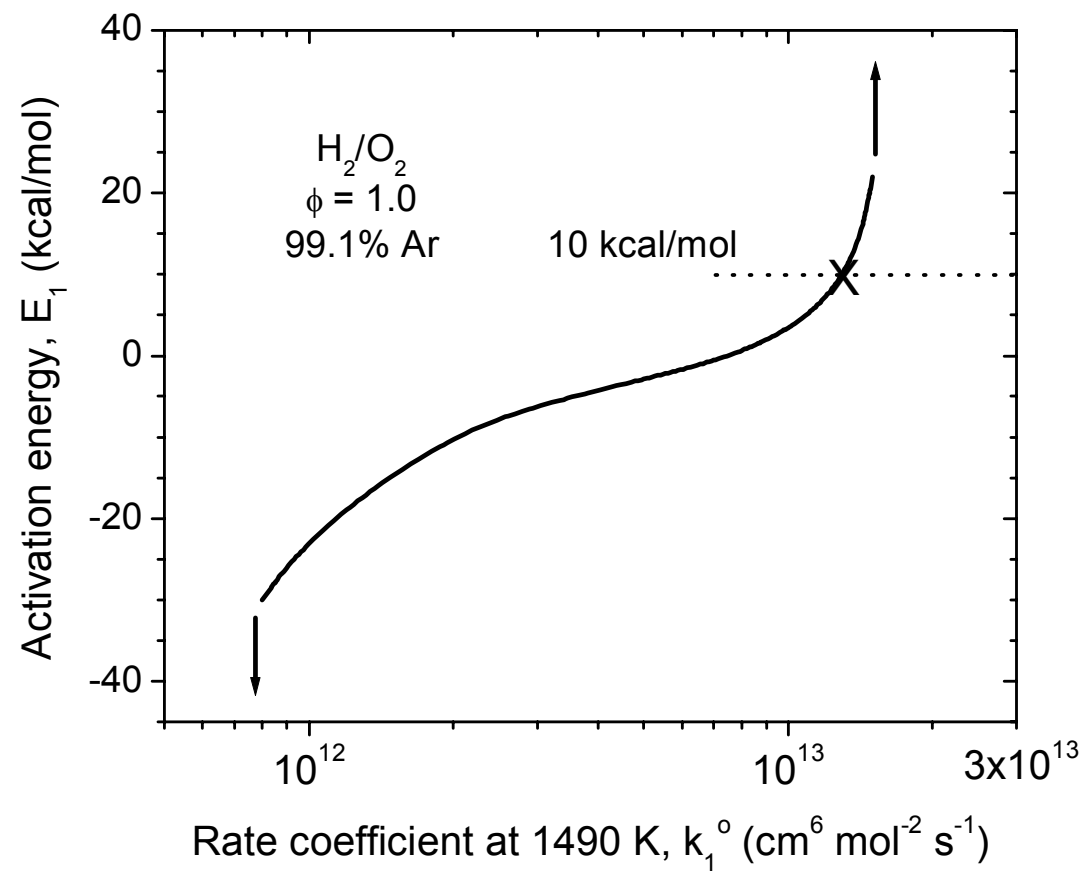

Figure 2. Functional dependence of $\mathrm{E}_{1}$ on $\mathrm{k}_{1}{ }^{\mathrm{o}}$ The routine converges for $8 \times 10^{11}<\mathrm{k}_{1}{ }^{\mathrm{o}}<1.4 \times 10^{13}$ $\mathrm{cm}^{6} \mathrm{~mol}^{-2} \mathrm{~s}^{-1}$. The final value of $E_{1}=10 \mathrm{kcal} / \mathrm{mol}$ lies within the range of convergence. The relationship was deduced from experiments with Mixtures 1 and 2. $\left(\mathrm{H}_{2} / \mathrm{O}_{2} / \mathrm{Ar}, \phi=1.0\right)$. 


\section{Rate of R0}

To next determine the rate of formation through $\mathrm{CH}+\mathrm{O}_{2}\left(\mathrm{k}_{0}\right)$ as a function of the reference rate, i.e. $\mathrm{k}_{0}\left(\mathrm{k}_{1}{ }^{0}\right)$, experiments were conducted in $\mathrm{H}_{2}$-based mixtures (Mixtures 2-4) and $\mathrm{CH}_{4}$-based mixtures (Mixtures 5-7) with constant optical settings maintained between $\mathrm{H}_{2}$-based mixtures and $\mathrm{CH}_{4}$-based mixtures expected to produce output signals of similar strength. Mixtures 5 and 6 contained some hydrogen, however the methane content dominated the $\mathrm{OH}^{*}$ production at these conditions. Hydrogen was added to these two mixtures simply to accelerate the global reaction so that the methane oxidation could be observed within the experimental test time.

Beginning with the $\mathrm{H}_{2}$-based mixtures, for a given $\mathrm{k}_{1}{ }^{\mathrm{o}}$ (with $\mathrm{E}_{1}$ calculated from the function found previously) the relationship of absolute concentration to voltage, $\left[\mathrm{OH}^{*}\right]_{\max }(\mathrm{V})$, was calculated, as in Fig. 3. Two sample curves are shown for two typical values of the reference rate, $\mathrm{k}_{1}{ }^{\mathrm{o}}=2.0 \times 10^{12} \mathrm{~cm}^{6} \mathrm{~mol}^{-2} \mathrm{~s}^{-1}\left(\mathrm{E}_{1}=-10 \mathrm{kcal} / \mathrm{mol}\right)$ and $\mathrm{k}_{1}{ }^{\mathrm{o}}=1.0 \times 10^{13} \mathrm{~cm}^{6} \mathrm{~mol}^{-2} \mathrm{~s}^{-1}\left(\mathrm{E}_{1}=3.4\right.$ $\mathrm{kcal} / \mathrm{mol}$ ). For each such value of $\mathrm{k}_{1}{ }^{\circ}$, a corresponding calibration curve was calculated assuming a linear relationship between maximum concentration and recorded voltage. As shown by the curve calculated assuming a factor-of-five increase in $\mathrm{k}_{2}$, this procedure is not sensitive to R2. This demonstrates that in the $\mathrm{H}_{2} / \mathrm{O}_{2}$ reaction, formation through $\mathrm{H}+\mathrm{O}+\mathrm{M}(\mathrm{R} 1)$ is the dominant step. For all conditions studied, sensitivity to the rate of $\mathrm{H}+\mathrm{OH}+\mathrm{OH}(\mathrm{R} 2)$ were found to be negligible. Hence, $\mathrm{k}_{2}$ need not be known with certainty, rather, it is important only to include this step in the model so that its qualitative effect on the $\mathrm{OH}^{*}$ calculations is properly represented. 
Rigorous determination of its rate coefficient was not necessary. Instead, mixtures and experiments were designed to focus on the two important formation reaction, $\mathrm{R} 0$ and $\mathrm{R} 1$.

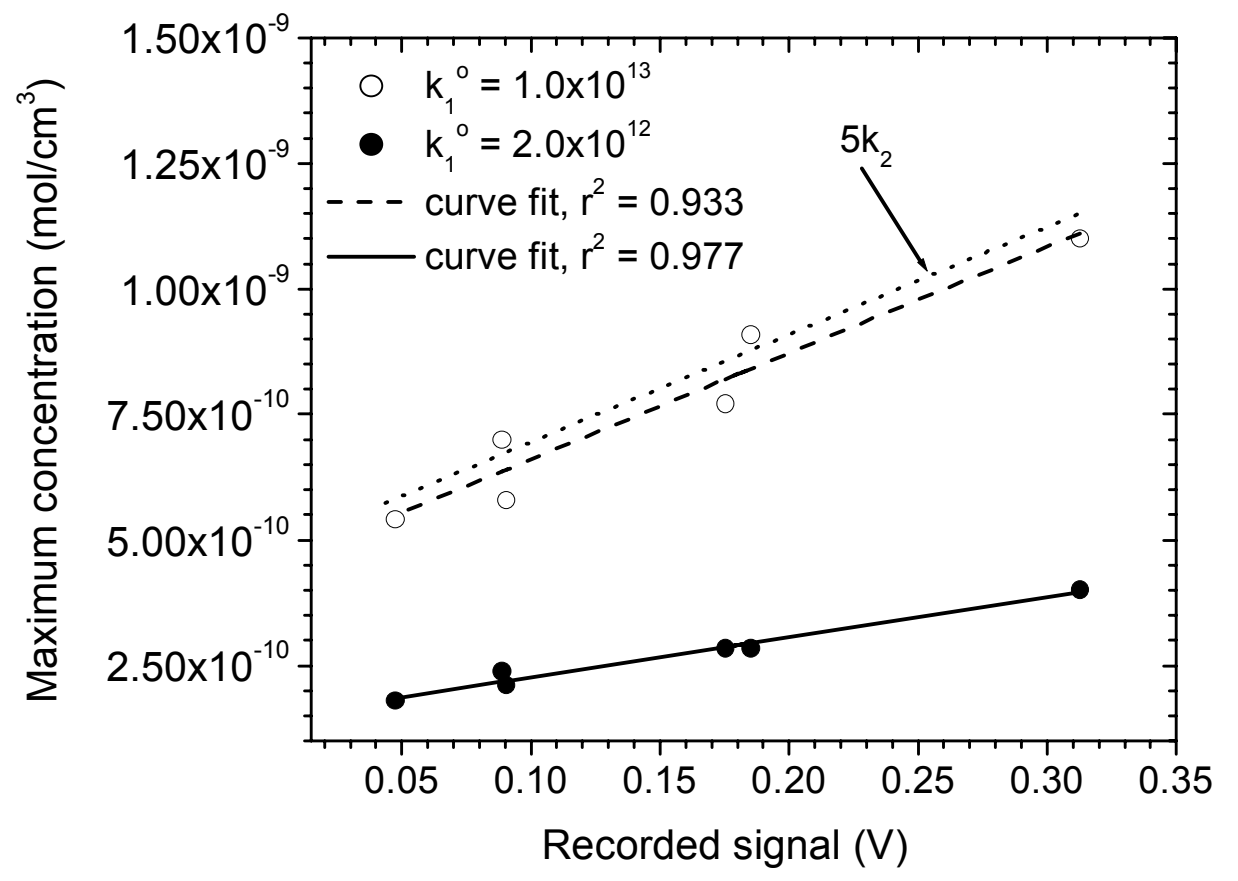

Figure 3. Sample calibration curves assuming two typical values of the reference rate, $\mathrm{k}_{1}{ }^{ }$. $\left[\mathrm{OH}^{*}\right]_{\max }(\mathrm{V})$ was then calculated from curve fits for various values of $\mathrm{k}_{1}{ }^{\mathrm{o}}$. The factor-of-five variation in the rate of $\mathrm{H}+\mathrm{OH}+\mathrm{OH}(\mathrm{R} 2)$ shows that the calibration is not sensitive to $\mathrm{k}_{2}$. This example is from Mixture 3 data, $\mathrm{P}_{\mathrm{avg}}=1.6 \mathrm{~atm}$.

The set of calibration curves found from $\mathrm{H}_{2} / \mathrm{O}_{2} / \mathrm{Ar}$ mixtures was then applied to the respective methane-based mixtures tested at constant optical settings, with the fuel and oxygen mole fractions chosen to produce similar voltages for both mixtures. For example, Mixture 3 was used to find calibration curves relevant to Mixture 5; thus, constant optical settings were 
maintained in the laboratory while studying both of these mixtures. In this fashion, the peak $\mathrm{OH}^{*}$ concentration in the methane-based mixture (e.g. Mixture 5) could be calculated for various values of the reference rate, $\mathrm{k}_{1}{ }^{\circ}$. Because the rate of formation through $\mathrm{CH}+\mathrm{O}_{2}(\mathrm{R} 0)$ controls the peak concentration in such methane-based mixtures, the corresponding rate coefficient, $\mathrm{k}_{0}$, could be calculated for each assumed value of $\mathrm{k}_{1}{ }^{\mathrm{o}}$, generating values of $\mathrm{k}_{0}$ across the range of temperatures measured. Two such calibrations are shown in Fig. 4, assuming the values of $\mathrm{k}_{1}{ }^{\mathrm{o}}$ from Fig. 3. Taking the average of the calculated values of $\mathrm{k}_{0}$, a nominal value of $\mathrm{k}_{0}$ was found for the assumed reference rate, generating another function, $\mathrm{k}_{0}\left(\mathrm{k}_{1}{ }^{\mathrm{o}}\right)$, shown in Fig. 5.

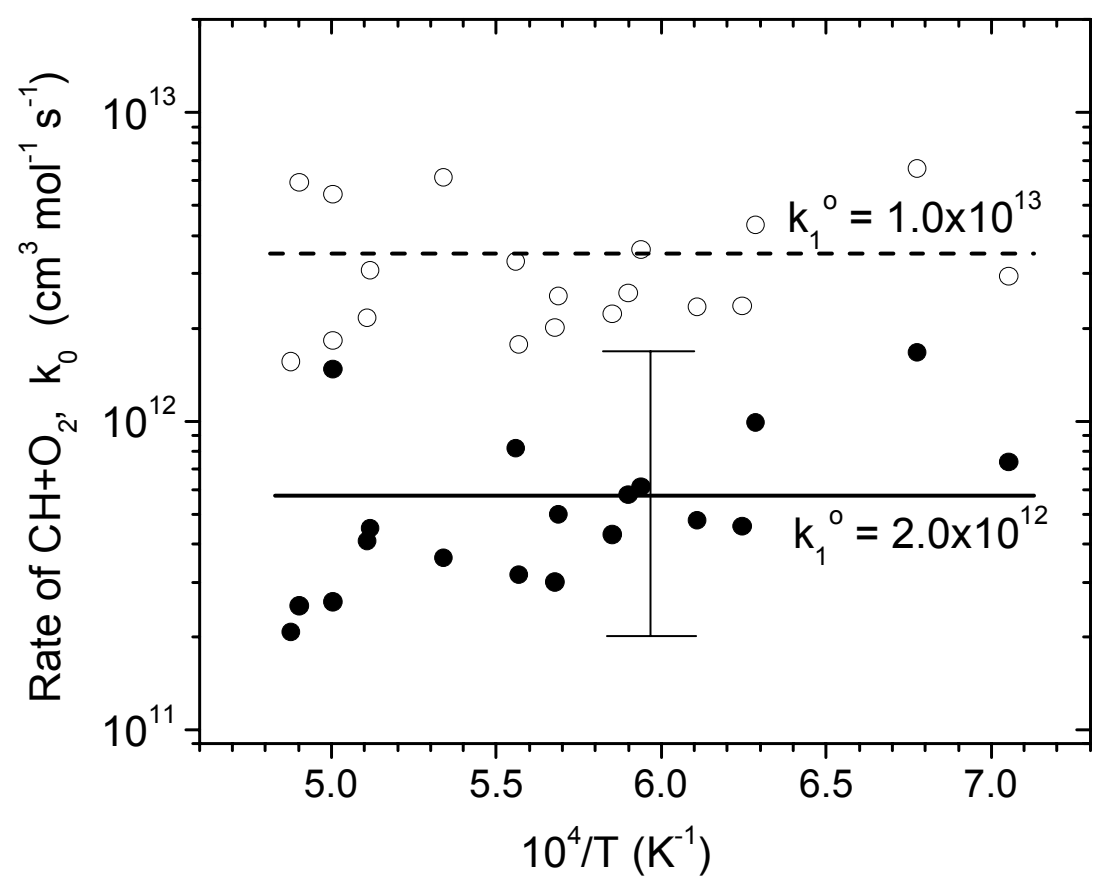

Figure 4. Rate of the $\mathrm{CH}+\mathrm{O}_{2}$ formation step $\left(\mathrm{k}_{0}\right)$ calculated for two typical values of $\mathrm{k}_{1}{ }^{\circ}$, across a range of temperatures. Error bars determined from maximum scatter indicate an uncertainty of a factor of three, to be reduced with subsequent calculations. Data are from Mixture 5, $\mathrm{P}_{\text {avg }}=0.96 \mathrm{~atm}$. 


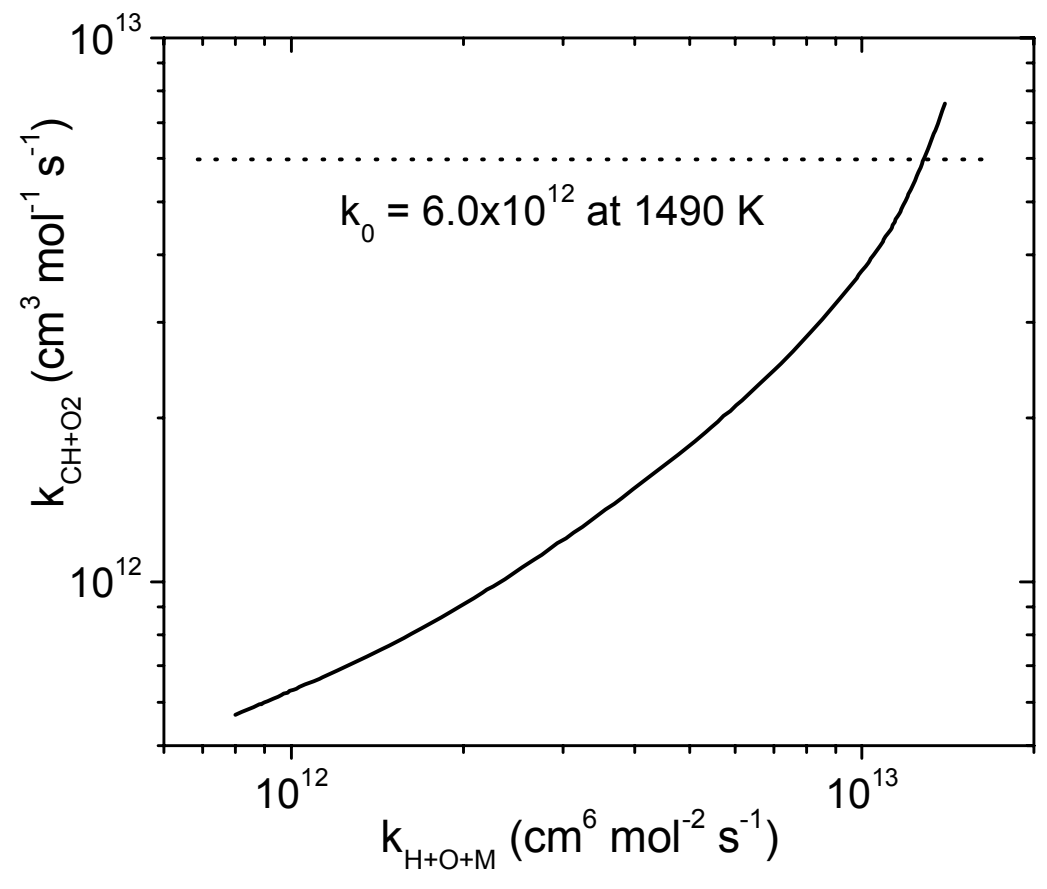

Figure 5. Functional dependence of $\mathrm{k}_{0}$ on $\mathrm{k}_{1}{ }^{0}$. The routine converges for $8 \times 10^{11}<\mathrm{k}_{1}{ }^{\mathrm{o}}<$ $1.4 \times 10^{13} \mathrm{~cm}^{6} \mathrm{~mol}^{-2} \mathrm{~s}^{-1}$. The final value of $\mathrm{k}_{0}=6.0 \times 10^{12} \mathrm{~cm}^{3} \mathrm{~mol}^{-1} \mathrm{~s}^{-1}$ (at $1490 \mathrm{~K}$ ) lies within the range of convergence, in a region of the curve where $\mathrm{k}_{0}$ is highly sensitive to $\mathrm{k}_{1}{ }^{\circ}$.

\section{Quenching Reactions}

The fitting routine described above was used to express the key rate parameters $\mathrm{k}_{0}$ and $\mathrm{E}_{1}$ as functions of the reference rate, $\mathrm{k}_{1}{ }^{\circ}$, with $1490 \mathrm{~K}$ taken as the reference temperature. Of the fitting parameters employed thus far, none are sensitive to the magnitude or temperature dependence of R2, or to the quenching reactions; hence, the literature values have been retained for these rates. The final step in the fitting routine employed mixtures of $\mathrm{H}_{2} / \mathrm{CH}_{4} / \mathrm{O}_{2} / \mathrm{Ar}$ with high 
$\mathrm{H}_{2} / \mathrm{CH}_{4}$ ratios specifically designed to produce dual peaks in the $\mathrm{OH}^{*}$ concentration curve. The ratio between the two peaks was used to uniquely determine the solution set. In mixtures of hydrogen and methane in which the $\mathrm{H}_{2} / \mathrm{CH}_{4}$ ratio is sufficiently large, the concentration profile shows two distinct peaks, the ratio between which is highly sensitive to the measured rates.

\section{$\underline{\text { Final Solution }}$}

With both rates $\mathrm{k}_{0}$ and $\mathrm{E}_{1}$ expressed as known functions of $\mathrm{k}_{1}{ }^{\mathrm{o}}$, one additional parameter was necessary to complete the optimization. Sensitivity analyses indicated that the shape of the $\mathrm{OH}^{*}$ profile in $\mathrm{H}_{2} / \mathrm{CH}_{4}$ mixtures is highly sensitive to the calculated solution set if $\mathrm{H}_{2}$ is present in amounts sufficient to produce post-ignition emission, as in Fig. 6. Both hydrogen formation reactions $(\mathrm{R} 1,2)$ are termolecular and hence, at atmospheric pressure, form $\mathrm{OH}^{*}$ in small quantities relative to the fast, bimolecular hydrocarbon formation step (R0). Consequently, the ratio of $\mathrm{H}_{2} / \mathrm{CH}_{4}$ must be large to produce such an effect; for example, mixtures 8 and 9 have $\mathrm{H}_{2} / \mathrm{CH}_{4}$ ratios of 80 and 340 , respectively. In the presence of even a small amount of $\mathrm{CH}$ (with $\mathrm{O}_{2}$ available in stoichiometric proportions) $\mathrm{R} 0$ will rival or exceed the $\mathrm{OH}^{*}$ yield by $\mathrm{R} 1$ and $\mathrm{R} 2$. If $\mathrm{H}_{2}$ and $\mathrm{CH}_{4}$ are mixed in the proper proportions, the contributions from the $\mathrm{CH}$ step (R0) and the H-atom steps $(\mathrm{R} 1,2)$ can be clearly seen, as in Fig. 6.

Preliminary calculations were performed to estimate the $\mathrm{H}_{2} / \mathrm{CH}_{4}$ ratio necessary to produce such a phenomenon. Estimates of the formation rates were taken from earlier measurements also conducted as a part of this work, as reported by Hall and Petersen [36]. Experimental work then revealed the $\mathrm{H}_{2} / \mathrm{CH}_{4}$ ratio necessary; this ratio was found to be about $300-400$ at high temperatures and on the order of 100 at lower temperatures. 


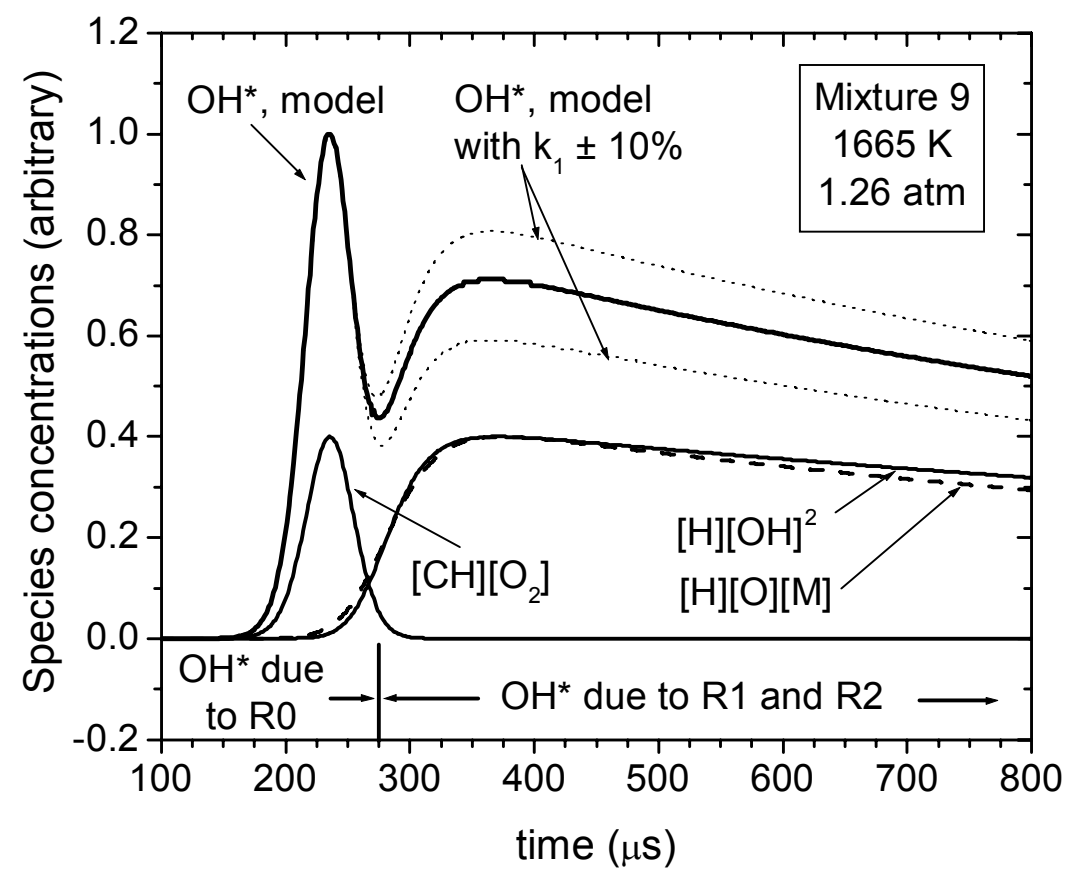

Figure 6. $\mathrm{OH}^{*}$ profile illustrating the contribution of each formation reaction as a function of time. The early portion of the profile ( $\mathrm{t}<275 \mu$ s) is due to $\mathrm{CH}+\mathrm{O}_{2}(\mathrm{R} 0)$ and the later portion ( $\mathrm{t}$ $>275 \mu \mathrm{s})$ is due to $\mathrm{H}+\mathrm{O}+\mathrm{M}$ and $\mathrm{H}+2 \mathrm{OH}(\mathrm{R} 1,2)$. Mixture 9, $1665 \mathrm{~K}, 1.26 \mathrm{~atm}$. The ratio between the two peaks is very sensitive to the solution set, as can be seen from the curves calculated assuming a 10\% increase and decrease in the value of the reference rate.

In Fig. 6, the portion of the $\mathrm{OH}^{*}$ profile from $175-275 \mu$ s is due almost exclusively to $\mathrm{CH}+\mathrm{O}_{2}(\mathrm{R} 0)$. At $\mathrm{t}=175 \mu \mathrm{s}$, when $\mathrm{OH}^{*}$ first begins to form, O-atoms have reached $2 \%$ of their peak values and $[\mathrm{OH}]$ is at $3 \%$ of its maximum. By $275 \mu$ s, as $\mathrm{CH}$ is disappearing, [O] and $[\mathrm{OH}]$ have reached 55 and $70 \%$, respectively. The portion of the $\mathrm{OH}^{*}$ seen after $275 \mu$ s is formed by $\mathrm{R} 1$ and $\mathrm{R} 2$. At $\mathrm{t}=275 \mu \mathrm{s},[\mathrm{CH}]$ has settled to $20 \%$ of its peak value and has returned to zero after 
$310 \mu$ s. Similar experimental profiles are shown in Figs. 7 and 8 corresponding to mixtures 8 and 9 , respectively. Because peak $\left[\mathrm{OH}^{*}\right]$ due to the $\mathrm{H}$-atom reactions $(\mathrm{R} 1,2)$ is nearly constant with temperature and that due to $\mathrm{CH}(\mathrm{R} 0)$ increases with temperature, on the normalized scales of Figs. 7 and 8 , the height of the second peak decreases with temperature relative to the first peak.

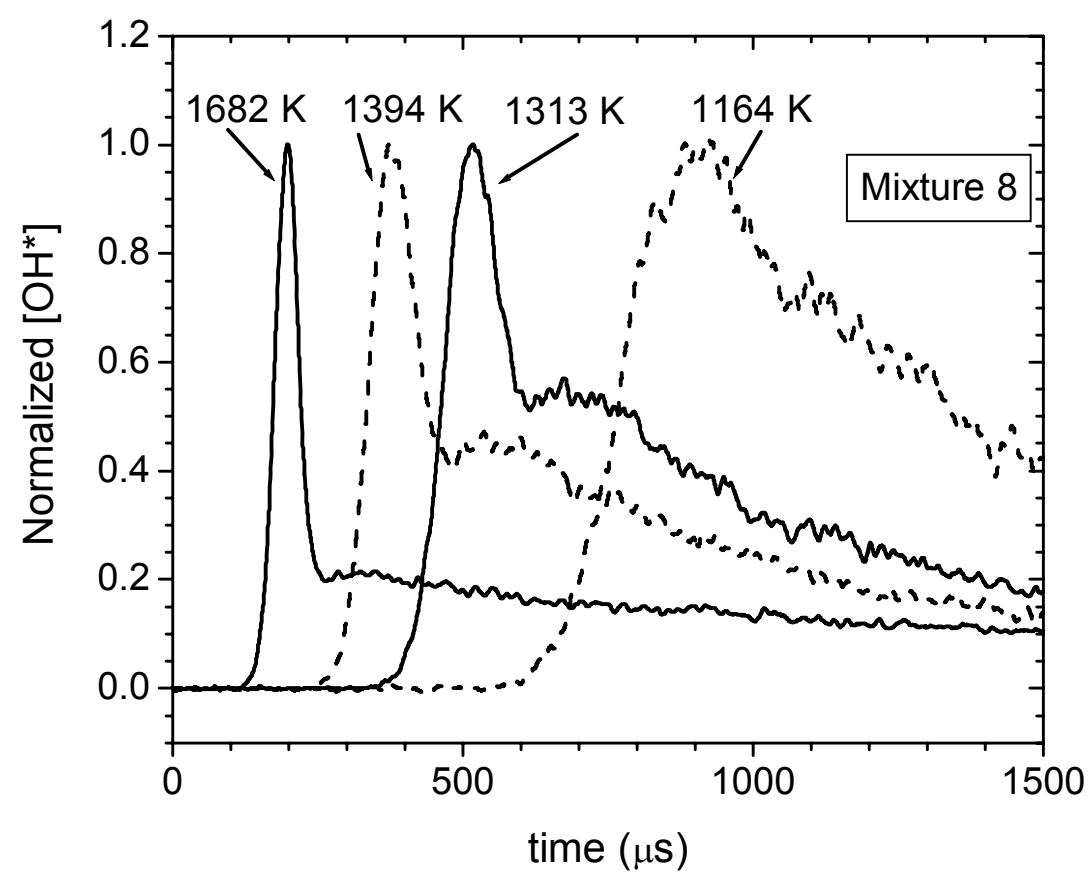

Figure 7. Typical experimental profiles from mixture $4, \mathrm{H}_{2} / \mathrm{CH}_{4}=80$, at pressures near $1.2 \mathrm{~atm}$. All profiles have been normalized to their peak values.

The solution set of 3 parameters $\left(\mathrm{k}_{0}, \mathrm{k}_{1}{ }^{\mathrm{o}}, \mathrm{E}_{1}\right)$ was then found by fitting the ratio of the two peaks. Several such solutions are shown in Figs. 9-11. The values of $k_{1}{ }^{\circ}$ found from the different experiments are similar, within $20 \%$ of each other, but the rate coefficient, $\mathrm{k}_{1}$, can have only one 
value at the reference temperature of $1490 \mathrm{~K}$. Hence, the nominal value was assigned to $\mathrm{k}_{1}{ }^{\circ}$, and variations in the solution set were used to determine the temperature dependence of $\mathrm{k}_{0}$.

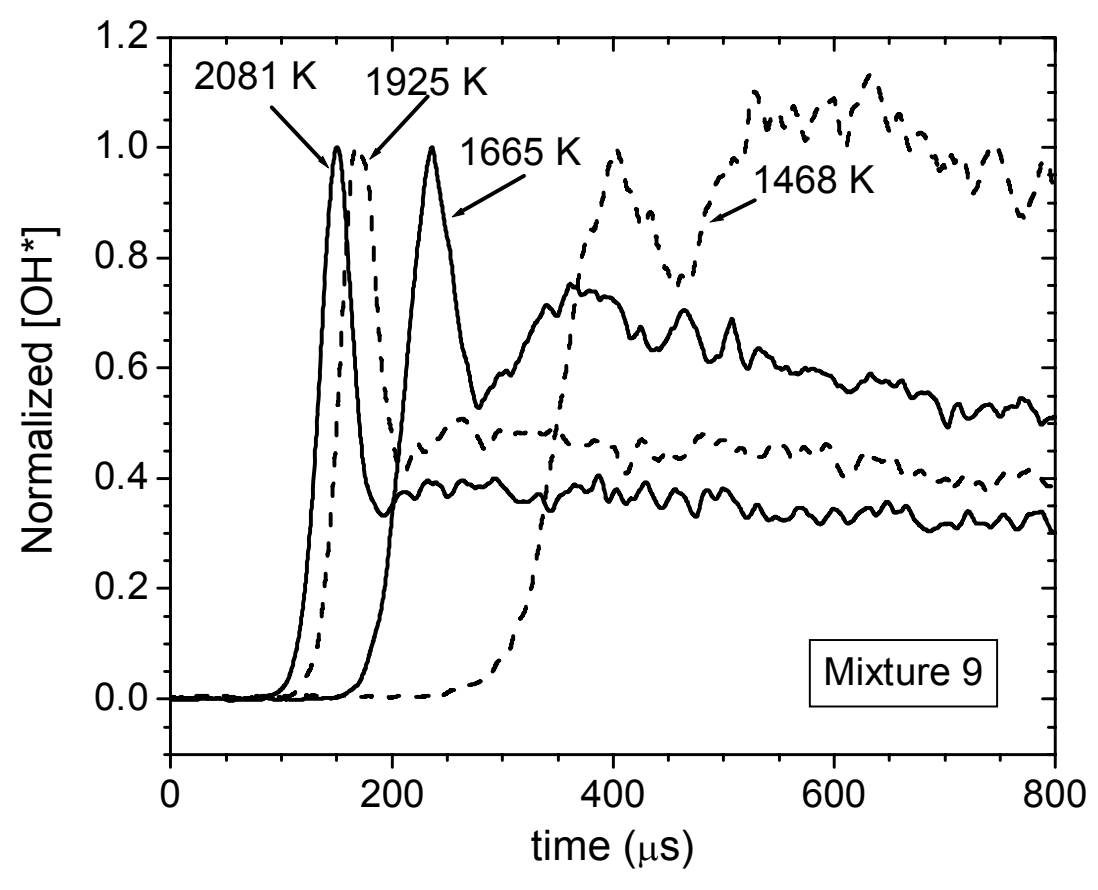

Figure 8. Typical experimental profiles from Mixture $9, \mathrm{H}_{2} / \mathrm{CH}_{4}=340$, at pressures near 1.1 atm. All profiles have been normalized to their peak values. The $1665-\mathrm{K}$ curve corresponds to the conditions of Fig. 6.

In the high-temperature case of Fig. 9, the methane kinetics dominate, producing a large first peak, with a second peak of about $50 \%$. The data are bounded by $10 \%$ of the nominal value. In the mid-temperature case shown in Fig. 10, the methane kinetics are not as fast, forming less $\mathrm{CH}$, so that the second peak is slightly greater than the first. At lower temperatures, such as in Fig. 11, a lower $\mathrm{H}_{2} / \mathrm{CH}_{4}$ ratio (Mixture 8) was necessary to produce the two-peak profiles. At the 
conditions shown, the data do not show two distinct peaks like those seen at higher temperatures. This is primarily because the methane kinetics are slow at $1164 \mathrm{~K}$, and very little $\mathrm{CH}$ is formed. Nonetheless, enough $\mathrm{CH}$ is present to contribute to the shape of the profile, and that shape can still be used to determine a unique value of the solution set at the experimental conditions. As shown in the figure, the shape of the $\mathrm{OH}^{*}$ profile is still quite sensitive to the rates measured. Despite the absence of a distinct second peak, the experimental curve is still bounded by $\mathrm{k}_{1}{ }^{\mathrm{T}} \pm$ $10 \%$.

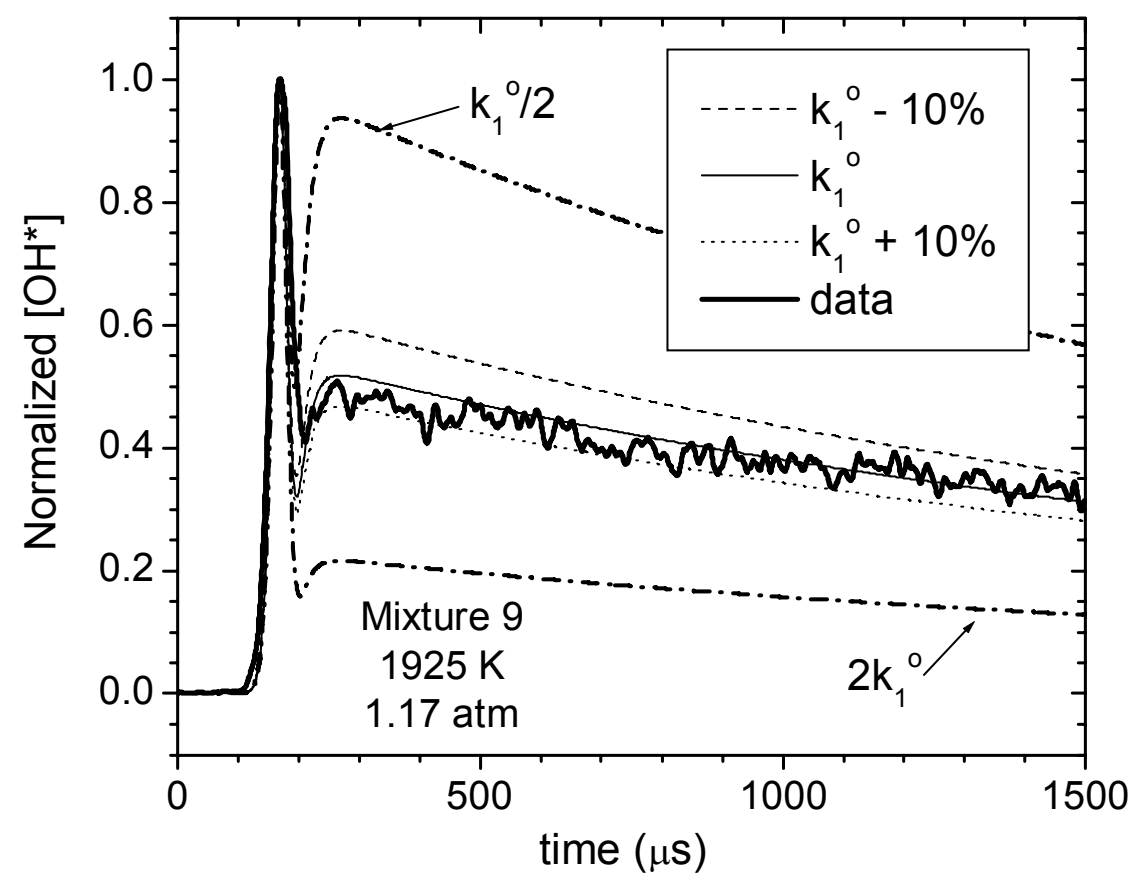

Figure 9. Solution set uniquely determined from a high-temperature experiment. Mixture 9, $\mathrm{H}_{2} / \mathrm{CH}_{4}=340,1.17 \mathrm{~atm}, 1925 \mathrm{~K}$. At these conditions, the H-atom peak is approximately $50 \%$ of the $\mathrm{CH}$ peak. 


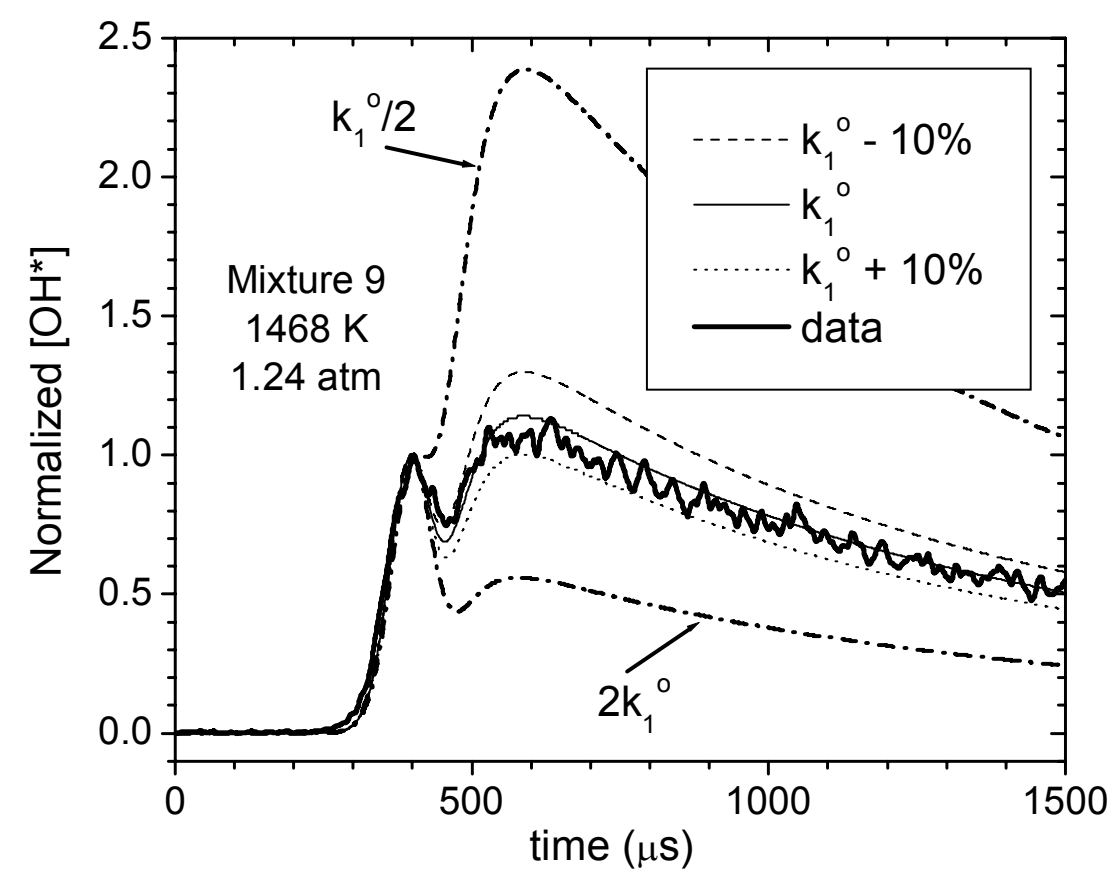

Figure 10. Solution set uniquely determined from a mid-temperature experiment. Mixture 9, $\mathrm{H}_{2} / \mathrm{CH}_{4}=340,1.24 \mathrm{~atm}, 1468 \mathrm{~K}$. At these conditions, the H-atom peak is approximately 1.1 times greater than the $\mathrm{CH}$ peak. 


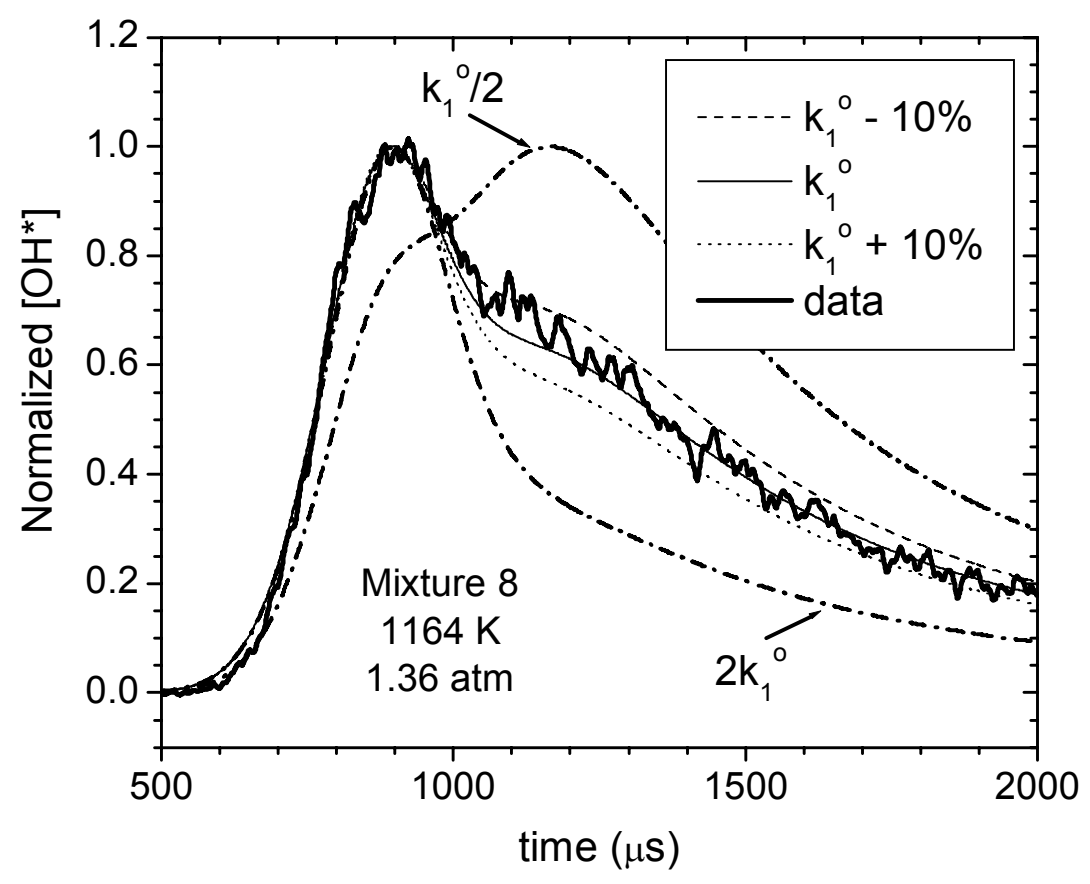

Figure 11. Solution set uniquely determined from a low-temperature experiment. Mixture 8, $\mathrm{H}_{2} / \mathrm{CH}_{4}=80,1.36 \mathrm{~atm}, 1164 \mathrm{~K}$. At these conditions, the two peaks are difficult to identify, but the shape of the profile is sensitive to the solution set. 


\section{CHAPTER FIVE: RESULTS}

By fitting dual peaks in the manner shown in Figs. 9-11, multiple measurements of the solution set were obtained. The nominal value of $\mathrm{k}_{1}{ }^{\mathrm{o}}$ was assigned to that rate, along with the activation energy derived previously $(10 \mathrm{kcal} / \mathrm{mol})$. Each experimental curve was then best-fit individually to obtain multiple measurements of the rate of formation through $\mathrm{CH}+\mathrm{O}_{2}\left(\mathrm{k}_{0}\right)$ over a range of temperatures. These data points, and the corresponding Arrhenius curve fit, are shown in Fig. 12. That Arrhenius expression is:

$$
\mathrm{k}_{0}=4.8 \times 10^{16} \mathrm{~T}^{-1} \exp (-5100 / \mathrm{RT})
$$

Previous measurements are shown for comparison. The new rate is considerably faster than those reported by Porter et al. [26] and Smith et al. [14]. This higher rate is necessary to predict the strong first peak due to $\mathrm{CH}$ in Mixtures 8 and 9 where methane (and hence $\mathrm{CH}$ ) is present in very small quantities relative to hydrogen, but yet the contribution from R0 is still significant. This new result should be used instead of the earlier higher recommendation by Hall and Petersen. [36]

Over the range of conditions studied, a value of $\mathrm{k}_{0}$ greater than those reported previously was necessary to fit the data of this study. However, the rate recommended herein is lower than previous measurements by Hall and Petersen [36] due primarily to the inclusion of R2. Formation through $\mathrm{H}+\mathrm{OH}+\mathrm{OH}(\mathrm{R} 2)$ was not included in earlier versions of this model [36], and, as noted previously, the $\mathrm{OH}^{*}$ calculations are sensitive only to the presence or absence of this reaction, not to its rate. Based on the suggestions of Smith et al. [15] and consideration of earlier literature sources, this reaction was included to better characterize the $\mathrm{OH}^{*}$ formation in hydrogen mixtures. 


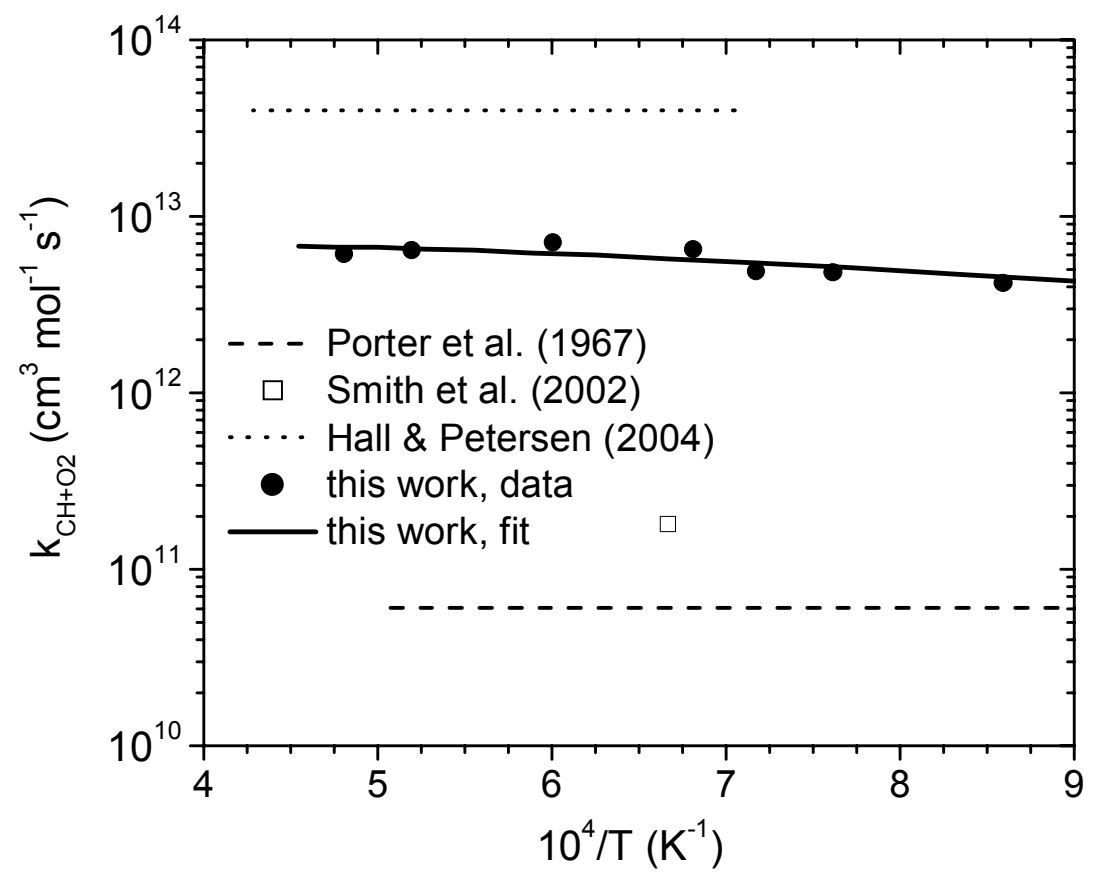

Figure 12. Data points and curve fit for the rate of $\mathrm{CH}+\mathrm{O}_{2}\left(\mathrm{k}_{0}\right)$. Previous high-temperature measurements by Porter et al. [26] and Smith et al. [14] are shown for comparison. The current results should be used rather than the earlier recommendation by Hall and Petersen [36].

For the nominal value of $k_{1}$, the fitting routine converged to the value shown in Fig. 13, which can be expressed in Arrhenius form as:

$$
\mathrm{k}_{1}=5.43 \times 10^{14} \exp (-10,000 / \mathrm{RT})
$$

with a collision efficiency of 0.7 for Ar. The collision efficiencies of all third-body species were assumed to be the same as those of the analogous reaction forming $\mathrm{OH}$ in the ground state. For the main collision partners, those efficiencies are: $\mathrm{H}_{2} / 2.00 / \mathrm{H}_{2} \mathrm{O} / 6.00 / \mathrm{CH}_{4} / 2.00 / \mathrm{CO} / 1.50$ / $\mathrm{CO}_{2} / 2.00 / \mathrm{C}_{2} \mathrm{H}_{6} / 3.00 / \mathrm{Ar} / 0.70 /$. The temperature dependence of this rate is in agreement with 
previous measurements, however, the magnitude is greater than reported by Smith et al. [15], Koike and Morinaga [20], and Hidaka et al. [19]. This larger magnitude is necessary to fit the dual-peak profiles with the ratio of $\mathrm{k}_{1}$ to $\mathrm{k}_{0}$ fixed by separate experiments such as in Figs. 4 and 5. This new result should also be used instead of the earlier value reported by Petersen et al. [37].

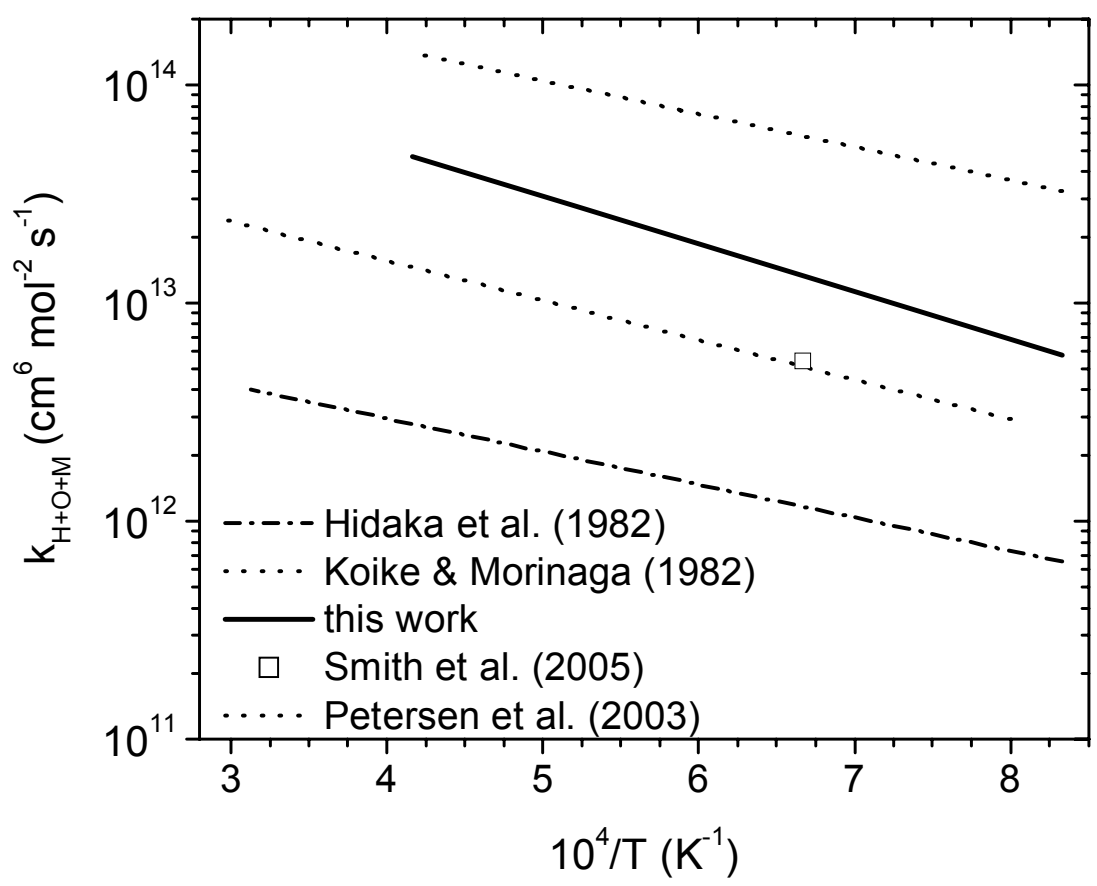

Figure 13. Rate expression derived herein for $\mathrm{H}+\mathrm{O}+\mathrm{M}\left(\mathrm{k}_{1}\right)$. Previous measurements by Hidaka et al. [19], Koike and Morinaga [20], and Smith et al. [15] are shown for comparison. The current results should be used rather than the earlier recommendation by Petersen et al. [37]. 
Figure 14 shows the range of values reported for the rate of formation through $\mathrm{H}+\mathrm{OH}+$ $\mathrm{OH}\left(\mathrm{k}_{2}\right)$. Based on sensitivities conducted in this study, it was not necessary to modify this rate beyond the starting value proposed by Smith et al. [15]. The fitting parameters employed in the fitting routine are sensitive only to the presence of this reaction, not to its rate. Variations in $\mathrm{k}_{2}$ anywhere within the range of values shown in Fig. 14 had a negligible effect on the calculated curves. This is due primarily to the small effect of this step where the reaction rate (as opposed to its rate coefficient) is proportional to the product of three small quantities, $[\mathrm{H}][\mathrm{OH}][\mathrm{OH}]$. At the conditions studied, these concentrations $\left(\mathrm{mol} / \mathrm{cm}^{3}\right)$ are much less than unity. Both concentrations $[\mathrm{H}]$ and $[\mathrm{OH}]$ are small relative to the mixture concentration $[\mathrm{M}]$ so that the dominant H-atom step is R1. R0 is more influential still because it is bi-molecular, so that its rate of reaction is proportional to the product of only two concentration terms, i.e. $[\mathrm{CH}]\left[\mathrm{O}_{2}\right]$. Therefore, the rate coefficient recommended by Smith et al. [15], which is near the average of the previous estimates, was retained for the new model. 


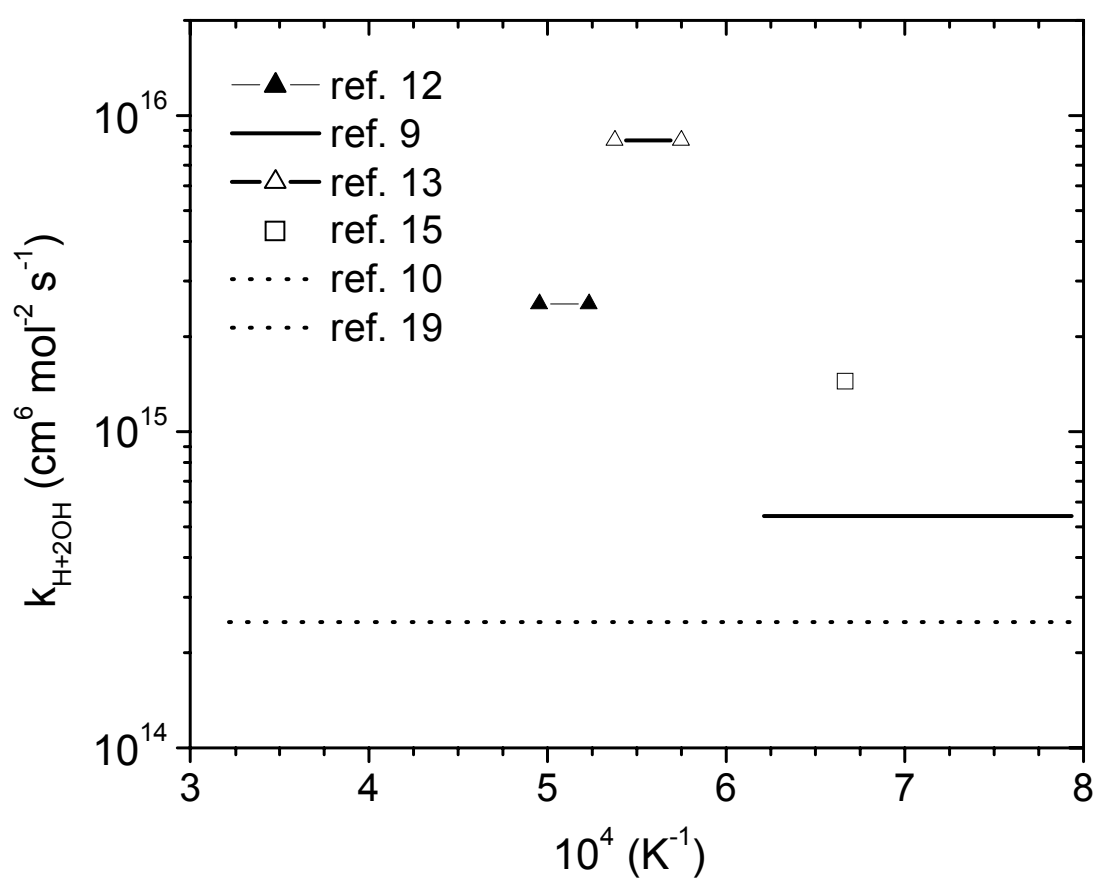

Figure 14. Rate expressions for $\mathrm{H}+\mathrm{OH}+\mathrm{OH}\left(\mathrm{k}_{2}\right)$ available in the literature. The most recent value of Smith et al. [15] was used in this work and not altered. Sensitivity analyses indicated that the fitting parameters employed are sensitive only to the presence of this reaction, not its rate. Citations are Hollander [12], Kaskan [9], Davis et al. [13], Smith et al. [15], Zeegers and Alkemade, [10] and Hidaka et al. [19].

Figure 15 shows the effect of uncertainties in the quenching rates on the measured values. The data and nominal values are shown for comparison. The curve was recalculated assuming an order-of-magnitude increase in each quenching rate. The largest source of uncertainty is $\mathrm{k}_{4}$, quenching with water, whose rate was taken from Tamura et al. [30]. An uncertainty in this rate of a factor of 10 produces an uncertainty in $\mathrm{k}_{1}$ of less than a factor of two. 


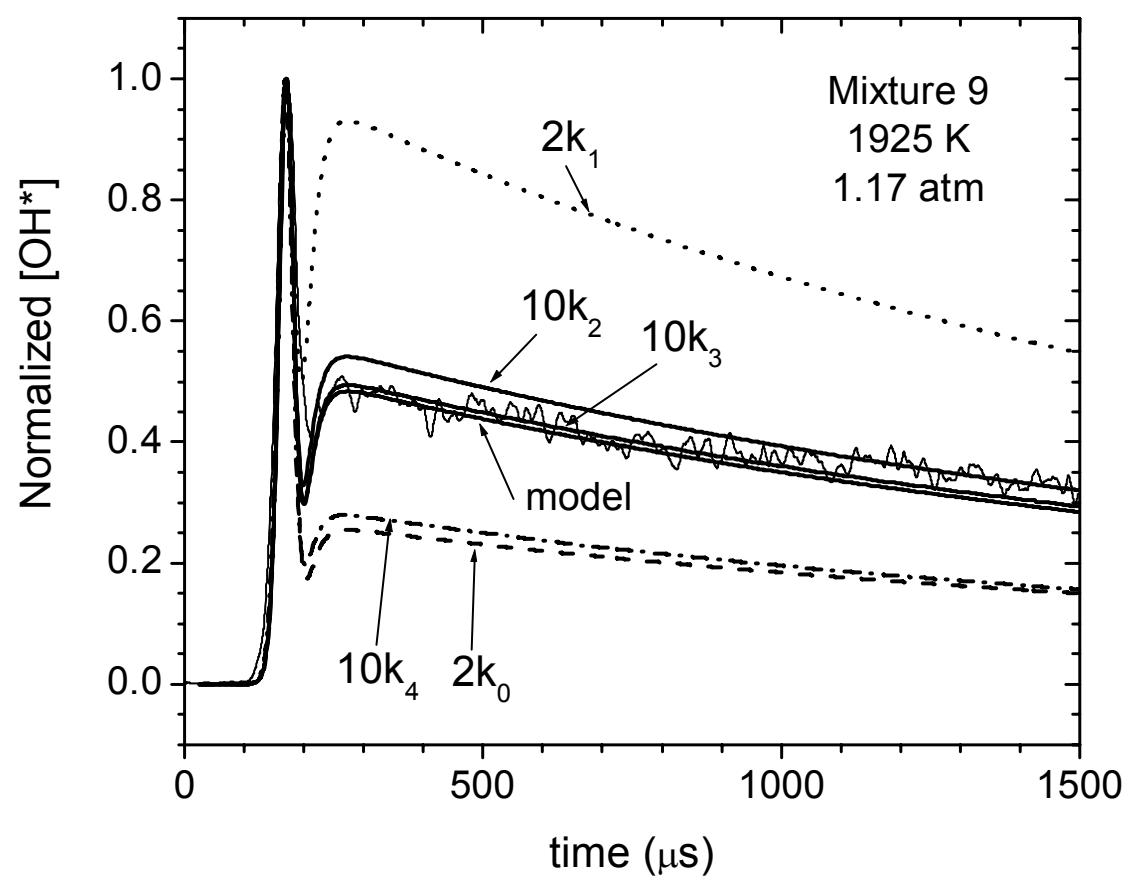

Figure 15. Effect of uncertainties in the individual rate coefficients. Quenching rates have been varied by a factor of ten, as has the rate of $\mathrm{H}+\mathrm{OH}+\mathrm{OH}\left(\mathrm{k}_{2}\right)$. The important formation rates $\left(\mathrm{k}_{0}\right.$ and $\mathrm{k}_{1}$ ) have been increased by a factor of two. Quenching with argon (R3) and formation through $\mathrm{H}+\mathrm{OH}+\mathrm{OH}(\mathrm{R} 2)$ have a negligible effect on the profile while quenching with water (R4) introduces uncertainty comparable to a factor-of-two uncertainty in $\mathrm{k}_{0}$.

As shown in Fig. 16, a factor-of-two increase in the solution set affects the curve more strongly than does a factor-of-ten increase in $\mathrm{k}_{4}$. Quenching with argon $\left(\mathrm{k}_{3}\right)$ has a much smaller effect; increasing this rate by an order of magnitude causes a change similar to that of $15 \%$ uncertainty in the solution set. The value of $k_{3}$ was taken from Paul et al. [21]. That R4 introduces more uncertainty is likely due to the delayed production of water. At the time of peak 
$\mathrm{CH}$ formation, very little water is present. In contrast, argon is present in equal proportions during both peak times so that its rate has little influence on the ratio between the two.

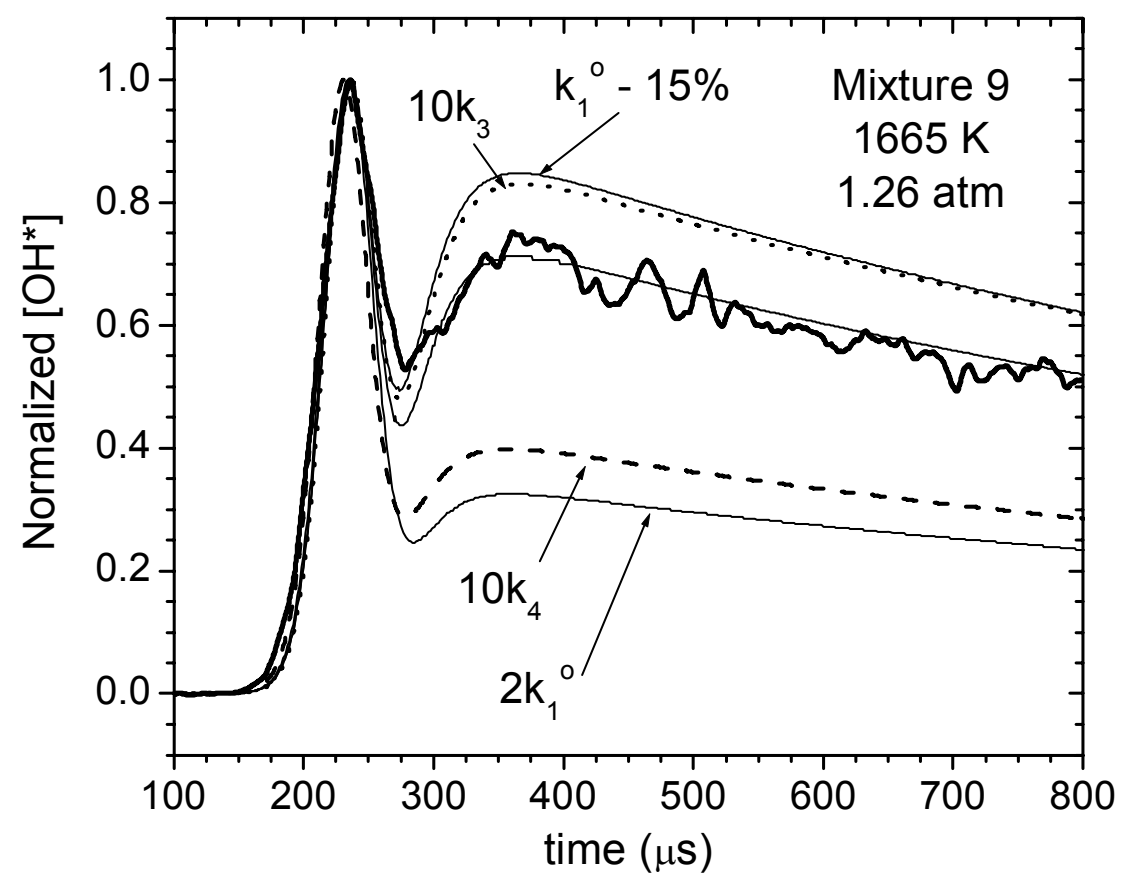

Figure 16. Effect of order-of-magnitude uncertainties in the quenching rates on the calculated profiles. Quenching with argon (R3) has a negligible effect on the measured parameters while quenching with water (R4) introduces uncertainty comparable to a factor-of-two uncertainty in the solution set.

In Fig. 17, the new model is evaluated relative to those previously available. Shown for comparison are calculations using the rates proposed by Smith et al. $[14,15]$ for reactions R0-R2. It should be noted that the quenching rates taken from Tamura et al. [30] (see Table 1) are the same as those used by Smith et al. $[14,15]$ except for $k_{3}$ (quenching with argon) which was taken 
from Paul et al. [21]. The model proposed by Porter et al. [26] does not include R1 or R2. However, if these steps are added using any available rate, the curve is similar in shape to the prediction of Smith et al. $[14,15]$. This result is due primarily to the low value of $\mathrm{k}_{0}$ suggested by those studies. With $\mathrm{k}_{0}$ on the order of $10^{10}$ or $10^{11} \mathrm{~cm}^{3} \mathrm{~mol}^{-1} \mathrm{~s}^{-1}$, the first peak due to $\mathrm{R} 0$ is diminished or obscured, indicating that a model assembled from multiple reference sources will not predict the subtleties of the $\mathrm{OH}^{*}$ chemistry that are evident in the dual-peak profiles measured in the present study. The model proposed earlier by Hall and Petersen [36] does predict the dual-peak behavior, although the refinements made in this work show improved agreement.

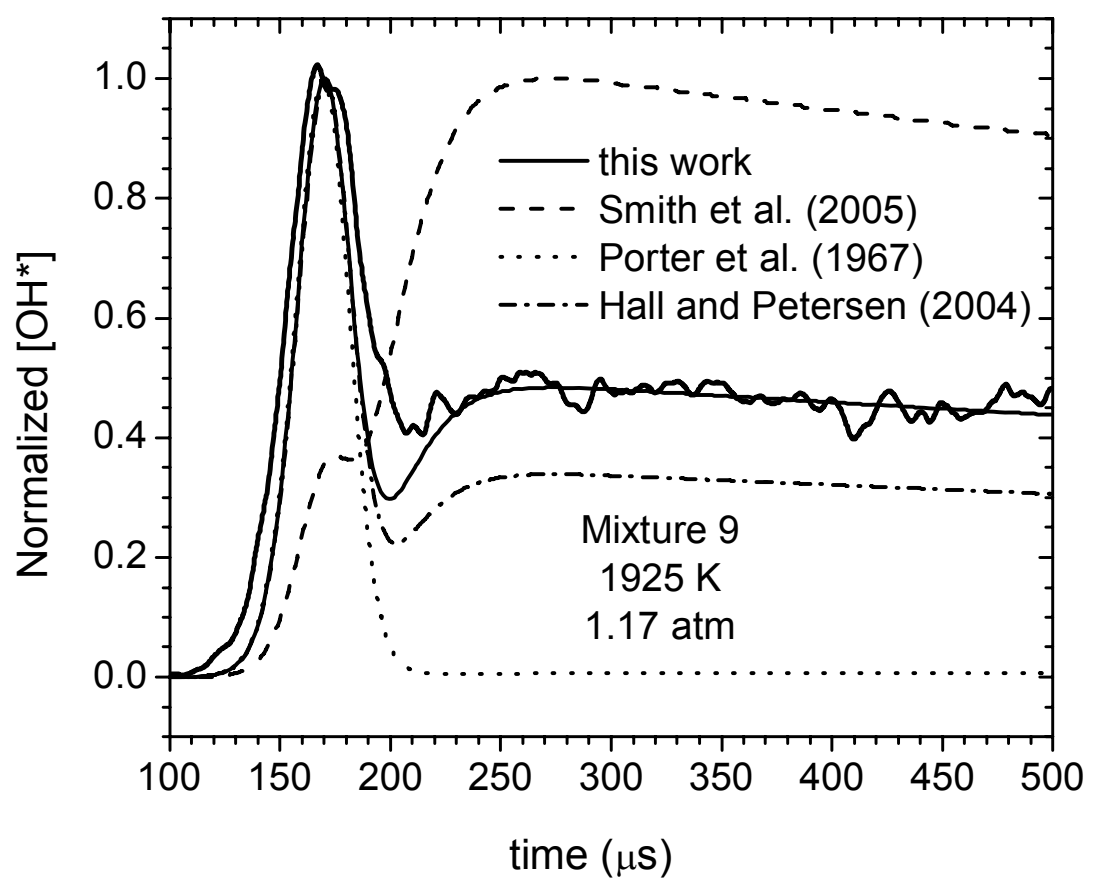

Figure 17. The present model evaluated relative to other models available in the literature. The model by Smith et al. [15] includes all three formation reactions (R0-R2), that of Porter et al. [26] includes only R0 and quenching steps. The earlier work by the authors did not include R2, but has a $\mathrm{k}_{1} / \mathrm{k}_{0}$ ratio similar to that of the present work. 


\section{CHAPTER SIX: SAMPLE APPLICATION: ETHANE OXIDATION}

As an example of the application of this work to a real problem, chemical kinetics modeling of $\mathrm{OH}^{*}$ measurements from a recent ethane $\left(\mathrm{C}_{2} \mathrm{H}_{6}\right)$ oxidation study was performed. The $\mathrm{C}_{2} \mathrm{H}_{6}$ data were reported previously by de Vries et al. [38]. The new $\mathrm{OH}^{*}$ model was used to study the detail of intermediate reaction chemistry in the ethane oxidation process.

\section{Modeling $\mathrm{OH}^{*}$ Concentration Profiles}

In a recent study of ethane oxidation and ignition [38], chemiluminescence obtained from electronically excited $\mathrm{CH}^{*}$ and $\mathrm{OH}^{*}$ was used as an optical diagnostic. This allowed for direct comparison because the recorded intensity is directly proportional to the concentration of the emitting species. To focus on the shape of the concentration curves, the plots presented here are normalized to their maximum values and aligned in time to exclude the effect of the different ignition delay times. Elementary reactions were added to each of the detailed mechanisms to account for formation and quenching of the excited-state compounds. The $\mathrm{OH}^{*}$ reactions were taken from this work, while $\mathrm{CH}^{*}$ reactions were taken from another work by Hall and Petersen [39]. For the current study, only the $\mathrm{OH}^{*}$ data were considered.

Each data point from the ethane ignition study [38] was deduced from a corresponding experimental profile; two typical examples are shown in Figs. 18-20. Two detailed kinetics mechanisms, with the $\mathrm{OH}^{*}$ reactions added, were compared to the experimental data. A mechanism by Wang and Laskin [40] and the San Diego mechanism [41,42] were considered. These models were selected because they have shown good agreement with recent studies of $\mathrm{C}_{2}$ - 
hydrocarbon oxidation and ignition. [43,44] Both contain the elementary reactions necessary to model $\mathrm{C}_{2} \mathrm{H}_{6}$ combustion.

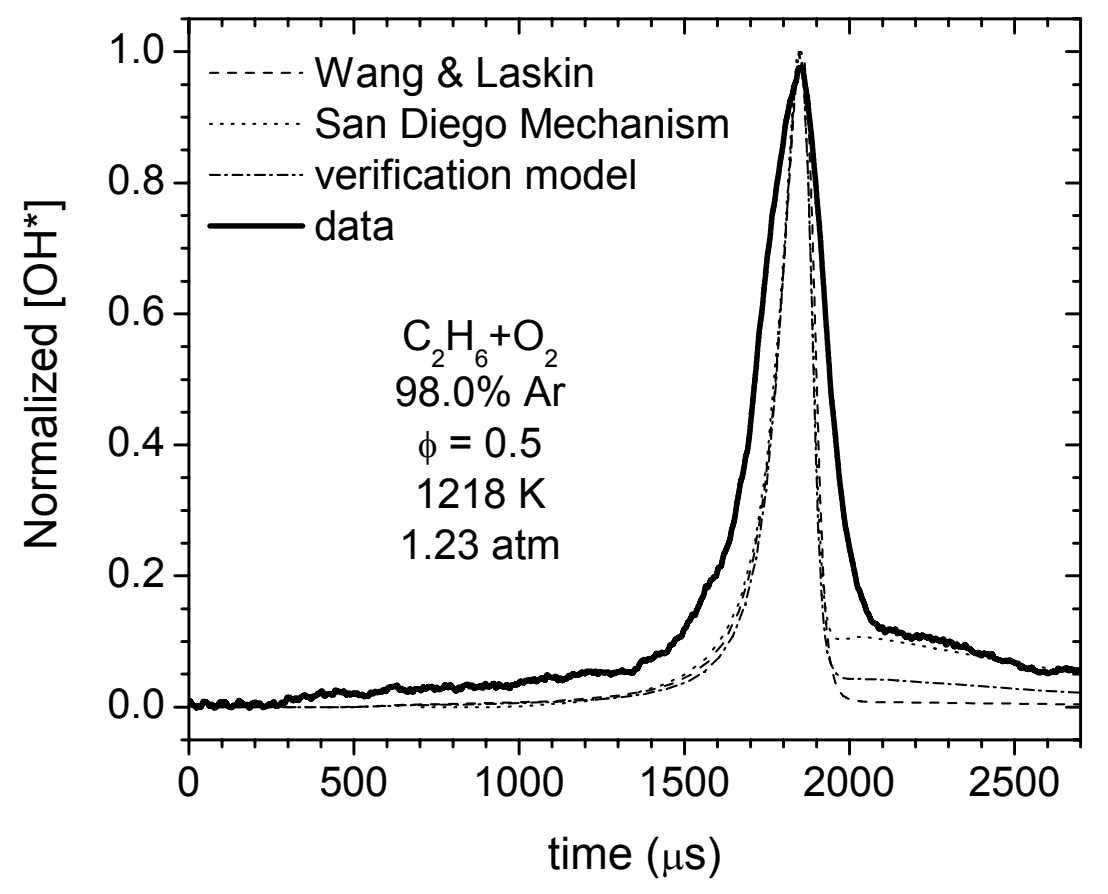

Figure 18. Typical $\mathrm{OH}^{*}$ profile for a low-temperature fuel-lean experiment. Both models show the rapid rise and fall of $\left[\mathrm{OH}^{*}\right]$ around ignition time, while only the San Diego Mechanism $[41,42]$ shows the post-ignition duration. The verification model was assembled to verify that the reactions identified in the text affect the shape of the curve.

The fuel-lean case (Fig. 18) displays the key features seen in most of the data. Of particular interest are the initial rise and fall of $\left[\mathrm{OH}^{*}\right]$ initially and then the gradual settling at later times. The ability of the models to reproduce these two aspects of the curve provides important information regarding the chemistry of $\mathrm{OH}^{*}$ precursor compounds, especially $\mathrm{CH}, \mathrm{H}-$ 
atoms and $\mathrm{O}$-atoms. As discussed previously, the steep rise and fall of $\left[\mathrm{OH}^{*}\right]$ seen initially from $1500-2000 \mu \mathrm{s}$ is due to the fast bi-molecular reaction of $\mathrm{CH}$ radicals with oxygen molecules (R0) and the $\mathrm{OH}^{*}$ present later in the reaction (for $\mathrm{t}>2000 \mu$ s in Fig. 18) is due primarily to the termolecular recombination step (R1). Thus, the ratio of the initial peak to the settling plateau provides a good test of the model's ground-state chemistry. Calculations at the conditions studied showed that both models agree regarding the absolute concentration of $\mathrm{H}$-atoms and $\mathrm{O}$-atoms formed, with peak levels differing by less than $25 \%$. Hence, it is reasonable to assume that the hydrogen/oxygen kinetics are well-known. The other reactant in $\mathrm{R} 0$ is $\mathrm{O}_{2}$, the initial concentration of which is specified by the test mixture composition, and $\mathrm{O}_{2}$ depletion is the same between both models. However, the two models predict significantly different levels of $\mathrm{CH}$ formation, with the model of Wang and Laskin [40] showing a greater peak [CH] and the San Diego Mechanism [41,42] generally showing the post-ignition duration. This suggests that the shape of the experimental profile can provide information regarding the level of $\mathrm{CH}$ formation. Over the range of conditions studied, the model of Wang and Laskin [40] generally shows less settling concentration, suggesting that it forms too much $\mathrm{CH}$ near the peak time. This conclusion is validated in the following section using the $\left[\mathrm{OH}^{*}\right]$ calibration. To better understand the $\mathrm{CH}$ production kinetics, the rate of $\mathrm{CH}$ production was calculated for each $\mathrm{CH}$-formation step at the conditions of Fig. 18; the rates of production by the most important steps are shown in Fig. 19. The main $\mathrm{CH}$ formation pathway for saturated hydrocarbons is $\mathrm{CH}_{3} \rightarrow \mathrm{CH}_{2} \rightarrow \mathrm{CH}$. Specifically, $\mathrm{CH}$ forms via reactions of $\mathrm{CH}_{2}$ (triplet) with $\mathrm{H}$-atoms and hydroxyl radicals.

$$
\begin{gathered}
\mathrm{CH}_{2}+\mathrm{H} \rightleftarrows \mathrm{CH}+\mathrm{H}_{2} \\
\mathrm{CH}_{2}+\mathrm{OH} \rightleftarrows \mathrm{CH}+\mathrm{H}_{2} \mathrm{O}
\end{gathered}
$$


$\mathrm{CH}$ is consumed by a reaction analogous to $\mathrm{R} 0$, which competes for both $\mathrm{OH}^{*}$ precursors.

$$
\mathrm{CH}+\mathrm{O}_{2} \rightleftarrows \mathrm{HCO}+\mathrm{O}
$$

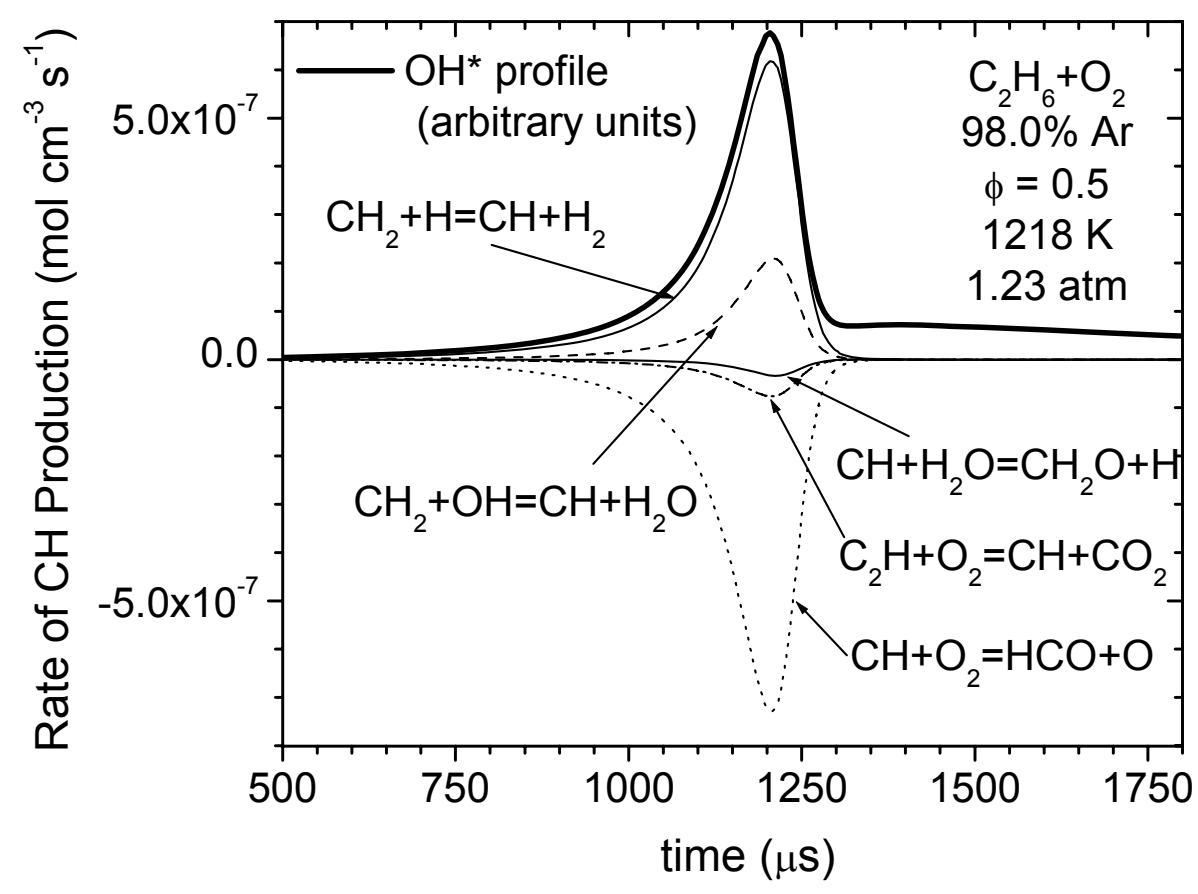

Figure 19. Rate of $\mathrm{CH}$ production at the conditions of Fig. 18. The five reactions shown make the largest contribution to $\mathrm{CH}$ concentration at the peak time. The shape of the $\mathrm{OH}^{*}$ profile provides information about the $\mathrm{CH}$ chemistry because $\mathrm{CH}$ is its primary precursor near ignition time.

Rates of $\mathrm{CH}$ production by these three steps are shown in Fig. 19 along with the leading secondary reactions. Calculations shown are from the San Diego Mechanism, but the general conclusion that R93 and R126 (where reaction numbering refers to the notation from GRI-Mech 3.0 [35]) are the dominant $\mathrm{CH}$ formation steps is supported by both models. To verify that these 
reactions are the important formation pathways, an additional calculation was performed using the Wang and Laskin [40] model with updated $\mathrm{CH}$ rates. The rates employed in that mechanism are from GRI-Mech 1.2, updated rates from GRI version 3 [35] were used for R93, R125, and R126 to demonstrate the effect of these reactions on the $\mathrm{OH}^{*}$ profile. The results of this updated, or verification model, shown in Fig. 18, indicate that the identified reactions do affect the shape of the calculated profile. Based on this analysis, it is apparent that better agreement with the experimental profiles can be achieved by improving the $\mathrm{CH}$-formation mechanism. Modifications to the rate coefficients to fit all the experimental profiles is beyond the scope of this work and was not attempted, but the data presented herein do provide a basis for such work.

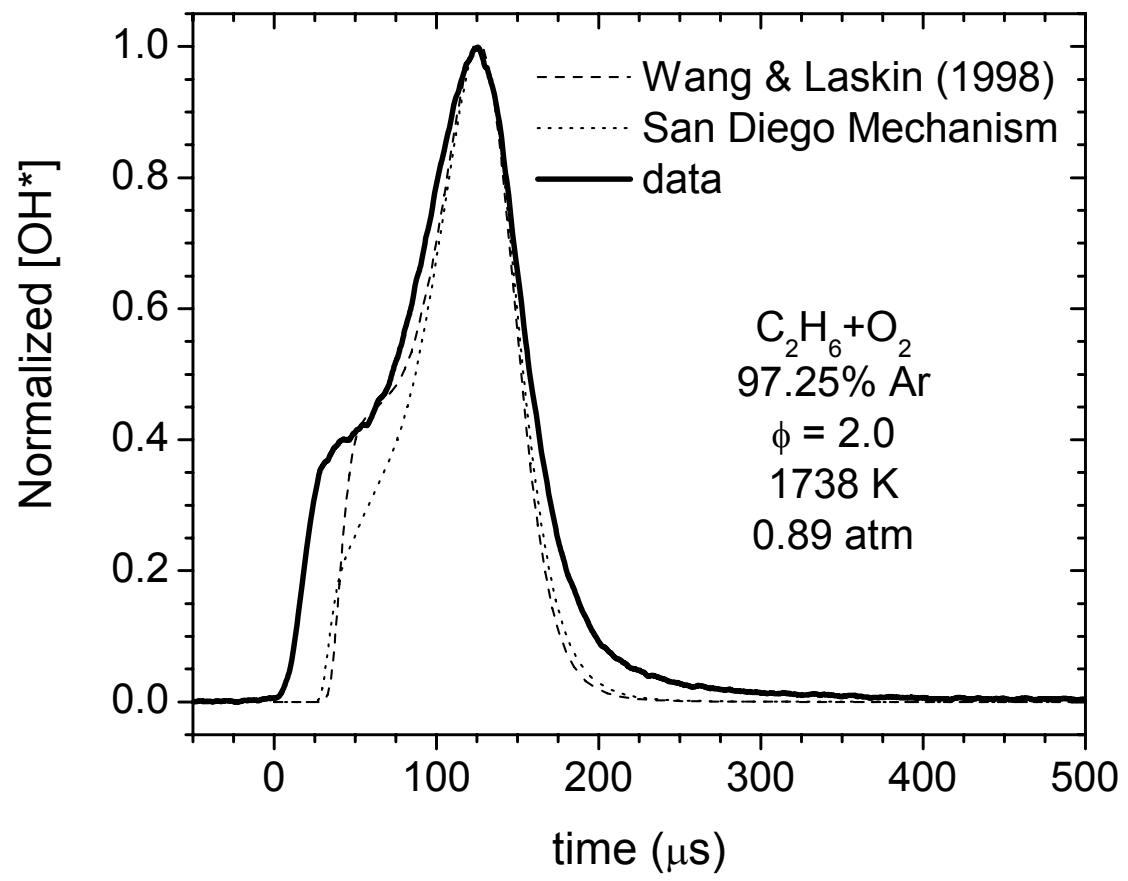

Figure 20. Typical experimental profile from a high-temperature fuel-rich experiment. Both models predict the important features of the curve at the conditions shown, especially the preignition rise in $\left[\mathrm{OH}^{*}\right]$. 
The fuel-rich profiles, such as the one shown in Fig. 20, exhibited a pre-ignition rise in $\mathrm{OH}^{*}$. This feature is shown by both models, but overall the Wang and Laskin model [40] was more successful in predicting the shape of the fuel-rich curves. It should be noted that the San Diego Mechanism [41,42] was not designed for fuel-rich conditions, especially for $\phi>1.5$.

\section{Absolute Concentration}

The final comparison of mechanism to data made in this study is for absolute concentration of the measured species. Absolute $\mathrm{OH}^{*}$ concentrations were calculated using the rates found by in this work. Experiments were conducted using a $\mathrm{H}_{2} / \mathrm{O}_{2} / \mathrm{Ar}$ mixture for which the detailed kinetics are well known. Subsequent tests were then performed in $\mathrm{C}_{2} \mathrm{H}_{6}$ mixtures maintaining constant optical settings throughout. The relationship of peak concentration to voltage was calculated from the hydrogen mixtures and then applied to the methane mixtures. Figure 21 shows peak concentrations from a typical $\mathrm{C}_{2} \mathrm{H}_{6} / \mathrm{O}_{2} / \mathrm{Ar}$ mixture on an Arrhenius diagram. The San Diego Mechanism [41,42] matches the magnitude more closely, while the Wang and Laskin [40] model matches the slope of the curve, but shows a larger magnitude. This supports the previous conclusion that the Wang and Laskin model [40] over-predicts the amount of $\mathrm{CH}$ formation, since $\mathrm{CH}$ is the main precursor for $\mathrm{OH}^{*}$ at the time of maximum concentration. The additional curve shown is from a verification model, in which the rates of the important $\mathrm{CH}$ formation steps (R93, R125, and R126) were updated as in GRI-Mech3.0 [35] to better model the $\mathrm{CH}$ chemistry. Although these small modifications were not sufficient to match the experimental data completely, they do shift the curve in the direction of better agreement. 


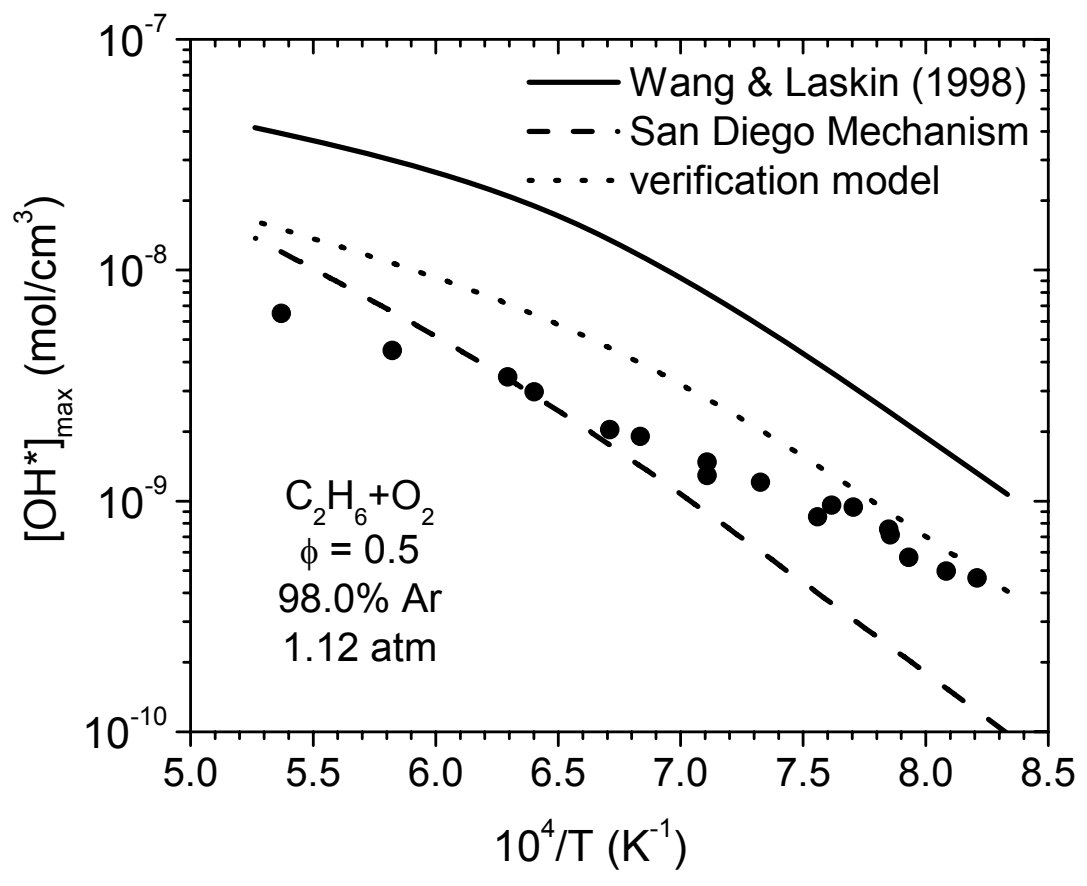

Figure 21. Absolute $\mathrm{OH}^{*}$ concentrations from calibrated experiments. Both models predict the $\left[\mathrm{OH}^{*}\right]$ within an order of magnitude, with the San Diego Mechanism [41,42] matching the magnitude more closely, and the Wang and Laskin model [40] matching the slope. A verification model was assembled using updated $\mathrm{CH}$ formation rates from GRI-Mech 3.0 [35] showing that the identified steps do affect the $\mathrm{OH}^{*}$ concentration. This plot demonstrates the use of the new model in a calibration to measure absolute concentration of $\mathrm{OH}^{*}$. 


\section{CHAPTER SEVEN: CONCLUSIONS}

$\mathrm{OH}^{*}$ emission spectroscopy is a cost-efficient combustion diagnostic requiring an accurate kinetics model for quantitative measurements. Sufficient data have now been collected to determine the ratios between the key $\mathrm{OH}^{*}$ formation rates and to identify a unique set of values to best-fit all data over the range of conditions studied. The temperature dependence of the rate of $\mathrm{H}+\mathrm{O}+\mathrm{M}\left(\mathrm{E}_{1}\right)$ was determined as a function of the magnitude of that reaction $\left(\mathrm{k}_{1}{ }^{\mathrm{o}}\right)$ by fitting the variation of peak intensity with temperature in $\mathrm{H}_{2} / \mathrm{O}_{2}$ mixtures. The rate of $\mathrm{CH}+\mathrm{O}_{2}$ ( $\mathrm{k}_{0}$ ) was then expressed as a function of $\mathrm{k}_{1}{ }^{\mathrm{o}}$ from experiments in $\mathrm{H}_{2} / \mathrm{O}_{2}$ and $\mathrm{CH}_{4} / \mathrm{O}_{2}$ with constant optical settings. The final values of all three rates were determined uniquely by fitting experimental curves from mixtures with high $\mathrm{H}_{2} / \mathrm{CH}_{4}$ ratios designed to produce two peaks in the $\mathrm{OH}^{*}$ concentration curve. The value of $\mathrm{k}_{0}$ was further refined by collecting dual-peak profiles at various temperatures.

The derived rate expressions (with units of $\mathrm{cm}$, mol, cal, and s) are as follows.

$$
\begin{aligned}
& \mathrm{k}_{0}=4.8 \times 10^{16} \mathrm{~T}^{-1} \exp (-5,100 / \mathrm{RT}) \\
& \mathrm{k}_{1}=5.43 \times 10^{14} \exp (-10,000 / \mathrm{RT})
\end{aligned}
$$

with a collision efficiency of 0.7 for argon pertaining to $\mathrm{k}_{1}$.

These new rates, along with appropriate quenching steps with reference rates, compose a complete, optimized kinetics model that is able to reproduce the entire range of data collected. This in turn can be used to calibrate the emission diagnostic for use in practical fuel/air mixtures. 


\section{APPENDIX A: RATE COEFFICIENTS AND ARRHENIUS KINETICS}


The goal of the present work has been to experimentally obtain rate coefficients for the important elementary reactions forming $\mathrm{OH}^{*}$ at the conditions of interest, i.e. high temperatures and atmospheric pressures. The following paragraphs review the basis of reaction kinetics theory pertaining to rate coefficients as used in modeling elementary reactions and their expression in Arrhenius form.

Most practical combustion processes involve the reaction of a fuel (in many cases a hydrocarbon) with oxygen (often from air). For example, the oxidation of methane can be expressed as the following global reaction.

$$
\mathrm{CH}_{4}+2 \mathrm{O}_{2} \rightarrow \mathrm{CO}_{2}+2 \mathrm{H}_{2} \mathrm{O}
$$

Such a reaction is called global because it expresses the net conversion of initial reactants to final products. The products of hydrocarbon oxidation are ideally $\mathrm{CO}_{2}$ and $\mathrm{H}_{2} \mathrm{O}$ when the reaction reaches its equilibrium state. However, the actual conversion of reactants to products requires some finite amount of time and takes place in a series of elementary reactions or steps. Some elementary reactions are faster than others, and their rates generally vary as functions of temperature, and sometimes also of pressure. The rate of a single elementary step is characterized by its rate coefficient, $\mathrm{k}$, which may itself be a function of temperature and pressure. The temperature dependence of a rate coefficient, $\mathrm{k}(\mathrm{T})$, is given by three Arrhenius parameters $(\mathrm{A}, \mathrm{n}, \mathrm{E})$ and expressed in Arrhenius form. The complete set of elementary reactions necessary to describe the global reaction along with their associated rate parameters is called a mechanism. Modeling a combustion reaction using this approach thus requires a detailed mechanism consisting of reactions and rate data. The complete reaction mechanism used herein 
is presented in Appendix D, however, explanation of the concepts of rate coefficients and Arrhenius expressions can be made using a simplified mechanism.

Consider for example the oxidation of hydrogen,

$$
\mathrm{H}_{2}+1 / 2 \mathrm{O}_{2} \rightarrow \mathrm{H}_{2} \mathrm{O}
$$

at temperatures greater than about $1200 \mathrm{~K}$ and pressures less than about $10 \mathrm{~atm}$, this is among the most well-known reactions, and its mechanism is well established. The $\mathrm{H}_{2} / \mathrm{O}_{2}$ reaction mechanism included in GRI-Mech 3.0 [35] consists of only 21 elementary steps. In the following example, that mechanism is reproduced in part to illustrate the concept of a rate coefficient. Selected reactions from the GRI $\mathrm{H}_{2} / \mathrm{O}_{2}$ mechanism are shown in Table 3. The mechanism has been reduced to 10 steps simply for the purpose of illustration; the entire reaction set should be used for actual calculations.

Table 3. Example mechanism. Selected rates are taken from the GRI-Mech 3.0 [35] methane mechanim. Collision efficiencies for third-body reactions have been omitted for clarity.

\begin{tabular}{lllll}
\hline$\#$ & reaction & $\mathrm{A}$ & $\mathrm{n}$ & $\mathrm{E}$ \\
\hline 1. & $\mathrm{H}+\mathrm{O}_{2} \rightleftarrows \mathrm{O}+\mathrm{OH}$ & $2.65 \times 10^{16}$ & -0.7 & 17,041 \\
2. & $\mathrm{O}+\mathrm{H}_{2} \rightleftarrows \mathrm{H}+\mathrm{OH}$ & $3.87 \times 10^{04}$ & 2.7 & 6260 \\
3. & $\mathrm{H}+\mathrm{O}_{2}+\mathrm{M} \rightleftarrows \mathrm{HO}_{2}+\mathrm{M}$ & $2.80 \times 10^{18}$ & -0.9 & 0.0 \\
4. & $\mathrm{H}+\mathrm{H}+\mathrm{M} \rightleftarrows \mathrm{H}_{2}+\mathrm{M}$ & $1.00 \times 10^{18}$ & -1.0 & 0.0 \\
5. & $\mathrm{H}+\mathrm{HO}_{2} \rightleftarrows \mathrm{O}+\mathrm{H}_{2} \mathrm{O}$ & $3.97 \times 10^{12}$ & 0.0 & 671.0 \\
6. & $\mathrm{H}+\mathrm{HO}_{2} \rightleftarrows \mathrm{O}_{2}+\mathrm{H}_{2}$ & $4.48 \times 10^{13}$ & 0.0 & 1068 \\
7. & $\mathrm{H}+\mathrm{H}_{2} \mathrm{O}_{2} \rightleftarrows \mathrm{HO}_{2}+\mathrm{H}_{2}$ & $1.21 \times 10^{07}$ & 2.0 & 5200 \\
8. & $\mathrm{H}+\mathrm{H}_{2} \mathrm{O}_{2} \rightleftarrows \mathrm{OH}^{13} \mathrm{H}_{2} \mathrm{O}$ & $1.00 \times 10^{13}$ & 0.0 & 3600 \\
9. & $\mathrm{OH}+\mathrm{H}_{2} \rightleftarrows \mathrm{H}+\mathrm{H}_{2} \mathrm{O}$ & $2.16 \times 10^{08}$ & 1.5 & 3430 \\
10. & $\mathrm{OH}+\mathrm{OH}^{2}+\mathrm{M} \rightleftarrows \mathrm{H}_{2} \mathrm{O}_{2}+\mathrm{M}$ & $7.40 \times 10^{13}$ & -0.4 & 0.0 \\
& Low pressure limit: & $2.30 \times 10^{18}$ & -0.9 & $-17,000$ \\
\hline
\end{tabular}


When modeling the transient aspects of a combustion reaction, one is generally interested in the concentration of some species as a function of time. The concentration of a given species, $[\mathrm{X}](\mathrm{t})$ can be predicted from the kinetics mechanism by solving a set of differential equations. One first-order ordinary differential equation can be written for each species in the mechanism. For example, the equation for the concentration of $\mathrm{OH}$ can be written in terms of the reactions that form and consume that compound. Each term is the product of the rate coefficient of that reaction and the concentrations of the reactant species, and one term is written for each reaction involving the species of interest ( $\mathrm{OH}$ in the example). A term is positive if the reaction forms $\mathrm{OH}$ and negative if it consumes $\mathrm{OH}$.

$$
\frac{d[\mathrm{OH}]}{d t}=\mathrm{k}_{1}[\mathrm{H}]\left[\mathrm{O}_{2}\right]+\mathrm{k}_{2}[\mathrm{O}]\left[\mathrm{H}_{2}\right]+\mathrm{k}_{8}[\mathrm{H}]\left[\mathrm{H}_{2} \mathrm{O}_{2}\right]-\mathrm{k}_{9}[\mathrm{OH}]\left[\mathrm{H}_{2}\right]-\mathrm{k}_{10}[\mathrm{OH}]^{2}[\mathrm{M}]+\Sigma(\text { rev terms })
$$

Where $[\mathrm{M}]$ is the mixture concentration, and $\mathrm{k}_{\mathrm{i}}$ is the rate coefficient of the $\mathrm{i}^{\text {th }}$ reaction in the forward direction, as written. Kinetics reactions are generally considered reversible so that the reverse reaction should be considered as well. In this example, the reverse terms can be written as follows.

$\Sigma($ rev terms $)=-\mathrm{k}_{1, \mathrm{R}}[\mathrm{OH}][\mathrm{O}]-\mathrm{k}_{2, \mathrm{R}}[\mathrm{OH}][\mathrm{H}]-\mathrm{k}_{8, \mathrm{R}}[\mathrm{OH}]\left[\mathrm{H}_{2} \mathrm{O}\right]+\mathrm{k}_{9, \mathrm{R}}[\mathrm{H}]\left[\mathrm{H}_{2} \mathrm{O}\right]+\mathrm{k}_{10, \mathrm{R}}\left[\mathrm{H}_{2} \mathrm{O}_{2}\right][\mathrm{M}]$

Similar equations can be written for each species in the model. Each first-order equation requires one initial condition. For reactant species (e.g. $\mathrm{H}_{2}$ and $\mathrm{O}_{2}$ ) the initial concentration is specified for the experiment; for all other species, the initial concentration is zero. For this work, 
the resulting set of differential equations was solved numerically using the chemkin collection software. [45] The reverse rate coefficient, $\mathrm{k}_{\mathrm{i}, \mathrm{R}}$ is related to the forward rate coefficient, $\mathrm{k}_{\mathrm{i}}$ by thermodynamics. The ratio of the forward rate to the reverse rate is equal to the equilibrium constant based on concentration, $\mathrm{K}_{\mathrm{c}}$ and for a bi-molecular reaction, this constant is equal to the equilibrium constant based on pressure, $\mathrm{K}_{\mathrm{p}}$.

$$
\frac{k_{i}(T)}{k_{i, R}(T)}=K_{c}(T)=K_{p}(T)=\exp \left(\frac{-\Delta G^{o}(T)}{R T}\right)
$$

Where $\Delta \mathrm{G}^{\mathrm{o}}(\mathrm{T})$ is the change in Gibbs function from reactants to products which can be found from the thermodynamic properties of each species in the $i^{\text {th }}$ reaction. Hence, the chemkin compiler requires an additional input file containing thermodynamic data for each species in the mechanism. A good discussion of the relationship between the forward and reverse rate coefficients and the equilibrium constant is given by Turns [46] in chapter 4 .

The standard mechanism involves three rate parameters for each reaction and thermodynamic data for the species participating in those reactions. The three rate parameters, typically denoted by A, n, and E, are often called the pre-exponential factor (or collision frequency), the temperature exponent, and the activation energy, respectively. These parameters express the rate coefficient as a function of temperature according to the modified-Arrhenius expression, i.e.

$$
\mathrm{k}=\mathrm{AT} \mathrm{T}^{\mathrm{n}} \exp (-\mathrm{E} / \mathrm{RT})
$$

The basic Arrhenius expression involves only two rate parameters, A and E and is written as,

$$
\mathrm{k}=\operatorname{Aexp}(-\mathrm{E} / \mathrm{RT}) \text {. }
$$

This expression conveys the underlying physics as originally suggested by Arrhenius. For molecules (or atoms) at some temperature, various reactions are possible. The likely and 
important reactions are included in the mechanism. At constant temperature, each reaction has a given collision frequency which is related to the number of molecules participating in that reaction per second, or more aptly, to the number of collisions occurring per second. This collision frequency is the pre-exponential factor, A. However, at finite temperatures, only certain collisions have sufficient energy to result in reaction; there is a threshold energy level and only collisions with energy in excess of this level will react. This energy barrier is the activation energy, E. The total fraction of collisions in the volume with energy in excess of this level is given by the exponential term, $\exp (-\mathrm{E} / \mathrm{RT})$. In the limit as $\mathrm{T}$ approaches infinity, this fraction approaches one, at which point all collisions have sufficient energy to react. For a finite temperature (and a positive activation energy) this fraction is less than one, giving the proportion of collisions in the volume with sufficient energy to react. Reactions that follow these simple principles and whose rate coefficients can be correlated by a two-parameter expression are said to follow Arrhenius kinetics.

Although all elementary reactions follow the basic physics outlined above, there are additional temperature effects related to the partition functions of the molecules and the allowed quantum states that may complicate the temperature dependence of the rate coefficient. In such cases, an additional temperature exponent may be necessary to express the $\mathrm{k}(\mathrm{T})$ curve. This is done by including the $\mathrm{T}^{\mathrm{n}}$ factor with " $\mathrm{n}$ " as a third parameter which is less physically significant and often comes merely from a curve-fit to experimental measurements of the rate coefficient at various temperatures. This three-parameter expression (such as employed for $\mathrm{k}_{0}$ in this work) is called a modified Arrhenius expression because it has been modified to include some curvature on an Arrhenius plot (i.e. a plot of $\operatorname{Ln}(\mathrm{k})$ vs. 1/T). 
Modified Arrhenius expressions are generally sufficient to completely define the rate of a bi-molecular reaction, such as R1 in Table 3. However, when a third body is involved, such as in R10 in Table 3, additional parameters may be necessary to express the rate coefficient as a function of pressure as well. In its simplest form, the $\mathrm{k}(\mathrm{P})$ expression involves a high-pressure limit and a low-pressure limit, each of which will vary with temperature according to separate Arrhenius expressions. Further details on the variation of $\mathrm{k}$ with $\mathrm{P}$ are given by Hall and Petersen [47] and Petersen et al. [48]. 


\section{APPENDIX B: HARD-SPHERE RATE CALCULATIONS}


This work has focused on the experimental determination of the rate coefficients of the two key $\mathrm{OH}^{*}$ formation reactions. It is also possible to calculate such rates theoretically, although such calculations are ultimately inaccurate and provide only estimates of the actual values. Nonetheless, theoretical estimates of the rate of a reaction may be useful for comparison.

The simplest method for calculating a rate is the hard-sphere model. This approach assumes that the molecules in the reaction behave as perfect spheres with rigid surfaces (like billiard balls) and the inter-molecular forces are negligible. Such assumptions deliberately ignore complicated quantum-mechanic effects in an effort to obtain a simplified model. The actual rate will differ from the calculated rate because molecules have polarity and will be more likely to react if in the proper orientation, whereas the hard-sphere model assumes the molecule is the same in any orientation. Hence the actual rate will usually be lower than the values suggested by the simplified calculation, with some scaling (or steric) factor, $\mathrm{P}$, which may be estimated from more sophisticated calculation methods (such as transition state theory) or measured directly. The most accurate approach is experimental. Just as the pre-exponential factor, A, is the rate of collisions between reactant molecules and the exponential factor, exp(-E/RT), gives the fraction of collisions with sufficient energy to cause reaction, the steric factor, P, represents the fraction of sufficiently energetic collisions that actually result in reaction. This steric factor must be found empirically to provide the accuracy necessary for kinetics modeling. For the present work, only the hard-sphere model will be considered, deferring to measurements for the final result. Additional discussion of the hard-sphere approach and more advanced methods such as transition state theory can be found in Pilling and Seakins [49] chapter 3, Wright [50] chapter 4, and Vincenti and Kruger [51] chapter 7. 
The hard-sphere calculation will serve as a simple validation of the results obtained in this work. The calculated rate coefficient consists of two terms, a theoretical collision frequency, $A_{\text {th }}$, and an experimental activation energy, E. Hence, for the simplest calculation, experimental data are needed unless an estimate of the activation is otherwise available.

The collision frequency, $\mathrm{A}_{\mathrm{th}}$, can be estimated from the size (radius) and the mass of the reactant species. Note also that this approach does not distinguish among the various product channels. $A_{\text {th }}$ is given by:

$$
A_{t h}=\left(\frac{8 k_{B} T}{\pi \mu}\right)^{1 / 2} \pi d^{2}
$$

where

$\mathrm{k}_{\mathrm{B}}=$ Boltzmann's constant $=1.381 \times 10^{-23} \mathrm{~J} / \mathrm{K}$

$\mathrm{d}=$ reactive distance $=\mathrm{r}_{\mathrm{A}}+\mathrm{r}_{\mathrm{B}}$

$r_{A}$ and $r_{B}$ are the hard-sphere radii of the reactant molecules

$\mu=$ reduced mass $=\left(\frac{m_{A} m_{B}}{m_{A}+m_{B}}\right)$

$\mathrm{m}_{\mathrm{A}}$ and $\mathrm{m}_{\mathrm{B}}$ are the masses of the reactant molecules. The mass of a molecule is equal to the molar mass as found on the periodic table divided by Avagadro's number.

For a simple estimate of the collision frequency, a typical reactive distance may be assumed. For two-atom molecules such as $\mathrm{CH}$ and $\mathrm{O}_{2}, \mathrm{~d} \approx 0.3 \mathrm{~nm}$. The order of magnitude of $\mathrm{A}_{0}$ may then be estimated as follows.

$$
\mu=\frac{m_{C H} m_{O 2}}{m_{C H}+m_{O 2}}=\frac{\left(2.16 \times 10^{-26} \mathrm{~kg}\right)\left(5.31 \times 10^{-26} \mathrm{~kg}\right)}{2.16 \times 10^{-26} \mathrm{~kg}+5.31 \times 10^{-26} \mathrm{~kg}}=1.54 \times 10^{-26} \mathrm{~kg}
$$


Assuming a reaction temperature of approximately $1500 \mathrm{~K}$,

$$
A_{t h}=\left(\frac{8\left(1.381 \times 10^{-23} \mathrm{~J} / \mathrm{K}\right)(1500 \mathrm{~K})}{\pi \times 1.54 \times 10^{-26} \mathrm{~kg}}\right)^{1 / 2} \pi\left(0.3 \times 10^{-9} \mathrm{~m}\right)^{2}=5.24 \times 10^{-16} \mathrm{~m}^{3} \mathrm{~s}^{-1}\left(\text { molecule } \mathrm{e}^{-1}\right)
$$

In the preferred rate coefficient units, this value is,

$$
A_{t h}=3.2 \times 10^{14} \mathrm{~cm}^{3} \mathrm{~mol}^{-1} \mathrm{~s}^{-1}
$$

Finally, for comparison to the experimental result, a two-parameter fit to the experimental data is necessary. The curvature of experimental rate measurements on an Arrhenius diagram is not taken into account by the simple hard-sphere model, and hence must be neglected in favor of a linear, two-parameter expression. Correlating the $\mathrm{k}_{0}$ data in Fig. 12 gives the following Arrhenius expression:

$$
k_{x p t}=1.2 \times 10^{13} \exp \left(\frac{-2300}{R T}\right) \mathrm{cm}^{3} \mathrm{~mol}^{-1} \mathrm{~s}^{-1}
$$

Thus, the experimental collision frequency, $\mathrm{A}_{\mathrm{xpt}}=1.2 \times 10^{13}$ is below the theoretical limit giving a steric factor of $\mathrm{P}=0.0375$ which is a typical order of magnitude for such values. This indicates that the measured rate is below the theoretical maximum and a physically realistic magnitude. 
APPENDIX C: SPECIES IN THE DETAILED MODEL 
The detailed mechanism is GRI-Mech 3.0 [35]. $\mathrm{OH}^{*}$ reactions and rates were added to this mechanism to perform kinetics calculations.

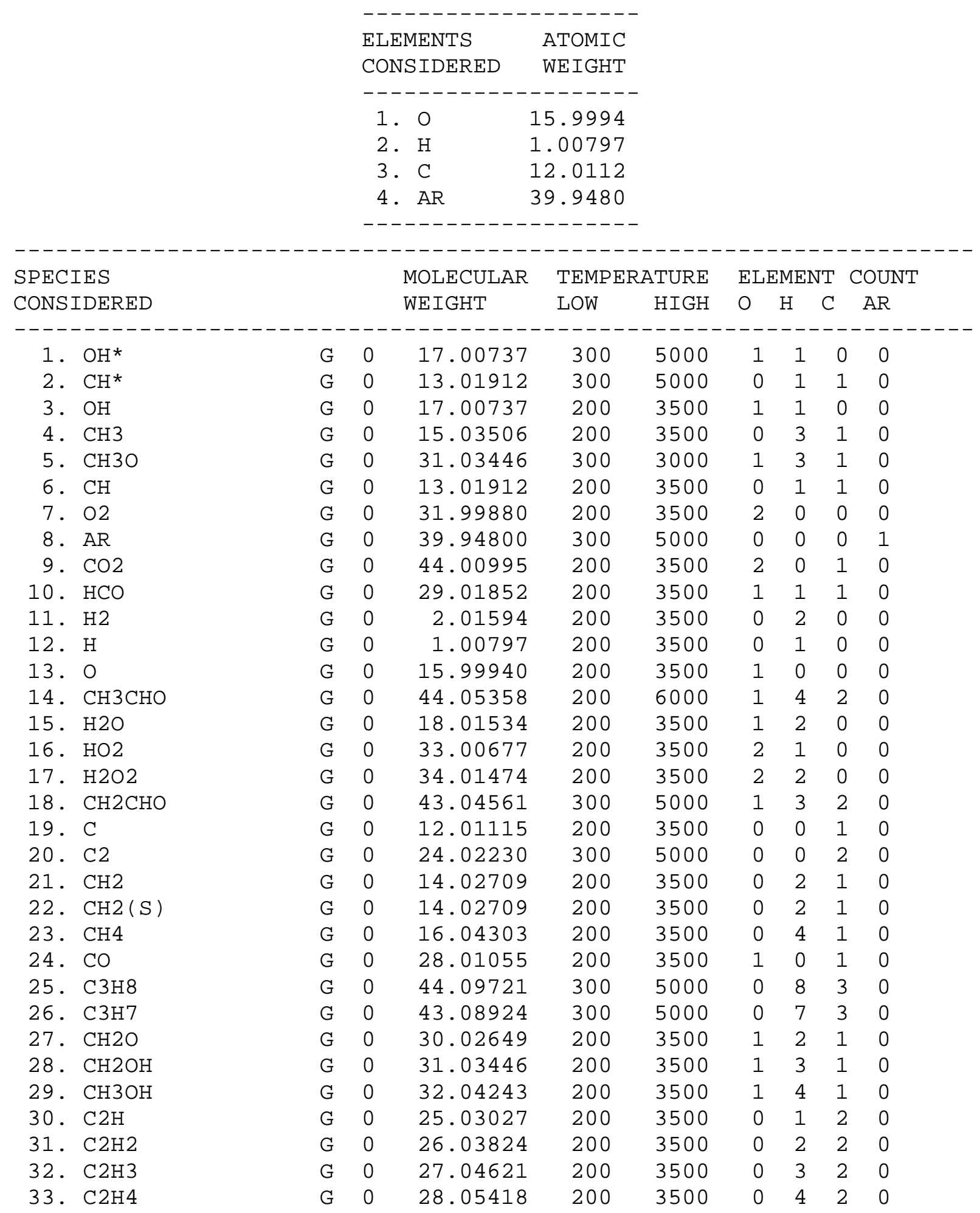


34. $\mathrm{C} 2 \mathrm{H} 5$

$\begin{array}{lllllllll}G & \odot & 29.06215 & 200 & 3500 & \odot & 5 & 2 & \odot\end{array}$

35. $\mathrm{C} 2 \mathrm{H} 6$

G $\odot \quad 30.07012 \quad 200 \quad 3500 \quad 006020$

36. $\mathrm{HCCO}$

G $\odot \quad 41.02967 \quad 300$

37. $\mathrm{CH} 2 \mathrm{CO}$

G $\odot \quad 42.03764 \quad 200$

$4000 \quad 1 \quad 1020$

38. $\mathrm{HCCOH}$

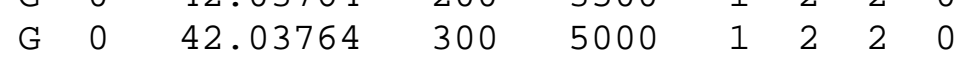


APPENDIX D: REACTIONS IN THE DETAILED MODEL 


\section{REACTIONS CONSIDERED}

1. $\mathrm{CH}+02=\mathrm{CO}+\mathrm{OH}^{*}$

2. $\mathrm{H}+\mathrm{O}+\mathrm{M}=\mathrm{OH}^{*}+\mathrm{M}$

3. $\mathrm{OH}+\mathrm{OH}+\mathrm{H}=\mathrm{OH}^{*}+\mathrm{H} 2 \mathrm{O}$

4. $\mathrm{OH}^{*}+\mathrm{AR}=\mathrm{OH}+\mathrm{AR}$

5. $\mathrm{OH}^{*}+\mathrm{H} 2 \mathrm{O}=\mathrm{OH}+\mathrm{H} 2 \mathrm{O}$

6. $\mathrm{OH}^{*}+\mathrm{CO} 2=\mathrm{OH}+\mathrm{CO} 2$

7. $\mathrm{OH}^{*}+\mathrm{CO}=\mathrm{OH}+\mathrm{CO}$

8. $\mathrm{OH}^{*}+\mathrm{H}=\mathrm{OH}+\mathrm{H}$

9. $\mathrm{OH}^{*}+\mathrm{H} 2=\mathrm{OH}+\mathrm{H} 2$

10. $\mathrm{OH}^{*}+\mathrm{O} 2=\mathrm{OH}+02$

11. $\mathrm{OH}^{*}+\mathrm{O}=\mathrm{OH}+\mathrm{O}$

12. $\mathrm{OH}^{\star}+\mathrm{OH}=\mathrm{OH}+\mathrm{OH}$

13. $\mathrm{OH}^{*}+\mathrm{CH} 4=\mathrm{OH}+\mathrm{CH} 4$

14. $\mathrm{OH}^{*}=\mathrm{OH}+\mathrm{HV}$

15. $\mathrm{C} 2 \mathrm{H}+\mathrm{O}=\mathrm{CO}+\mathrm{CH}^{*}$

16. $\mathrm{C}+\mathrm{H}+\mathrm{M}=\mathrm{CH}^{*}+\mathrm{M}$

17. $\mathrm{C} 2+\mathrm{OH}=\mathrm{CO}+\mathrm{CH}^{*}$

18. $\mathrm{C} 2 \mathrm{H}+02=\mathrm{CO} 2+\mathrm{CH}^{*}$

19. $\mathrm{CH}^{*}+\mathrm{AR}=\mathrm{CH}+\mathrm{AR}$

20. $\mathrm{CH}^{*}+\mathrm{H} 2 \mathrm{O}=\mathrm{CH}+\mathrm{H} 2 \mathrm{O}$

21. $\mathrm{CH}^{*}+\mathrm{CO}=\mathrm{CH}+\mathrm{CO}$

22. $\mathrm{CH}^{*}+\mathrm{CO} 2=\mathrm{CH}+\mathrm{CO} 2$

23. $\mathrm{CH}^{*}+\mathrm{O} 2=\mathrm{CH}+02$

24. $\mathrm{CH}^{*}+\mathrm{H} 2=\mathrm{CH}+\mathrm{H} 2$

25. $\mathrm{CH}^{*}+\mathrm{CH} 4=\mathrm{CH}+\mathrm{CH} 4$

26. $\mathrm{CH}^{*}=\mathrm{CH}+\mathrm{HV}$

27. $\mathrm{C} 2+\mathrm{H} 2=\mathrm{C} 2 \mathrm{H}+\mathrm{H}$

28. $\mathrm{CH}+\mathrm{CH}=\mathrm{C} 2+\mathrm{H} 2$

29. $\mathrm{C}+\mathrm{C}+\mathrm{M}=\mathrm{C} 2+\mathrm{M}$

30. $\mathrm{C}+\mathrm{CH}=\mathrm{C} 2+\mathrm{H}$

31. $\mathrm{O}+\mathrm{C} 2=\mathrm{C}+\mathrm{CO}$

32. $\mathrm{C} 2+\mathrm{O} 2=\mathrm{CO}+\mathrm{CO}$

33. $\mathrm{H}+02<=>0+O H$

34. $\mathrm{CH} 3+02<=>0+\mathrm{CH} 30$

35. $2 \mathrm{CH} 3<=>\mathrm{H}+\mathrm{C} 2 \mathrm{H} 5$

36. $\mathrm{O}+\mathrm{H} 2<=>\mathrm{H}+\mathrm{OH}$

37. $\mathrm{O}+\mathrm{H}+\mathrm{M}<=>\mathrm{OH}+\mathrm{M}$ $\mathrm{H} 2$

$\mathrm{H} 2 \mathrm{O}$

$\mathrm{CH} 4$

$\mathrm{CO}$

$\mathrm{CO} 2$

$\mathrm{C} 2 \mathrm{H} 6$

AR

38. $20+M<=>02+M$

$\mathrm{H} 2$

$\mathrm{H} 2 \mathrm{O}$

$\mathrm{CH} 4$

$\mathrm{CO}$

$\mathrm{CO} 2$

$\mathrm{C} 2 \mathrm{H} 6$

AR

39. $\mathrm{O}+\mathrm{HO} 2<=>\mathrm{OH}+\mathrm{O} 2$

40. $\mathrm{O}+\mathrm{H} 2 \mathrm{O} 2<=>\mathrm{OH}+\mathrm{HO} 2$

41. $\mathrm{O}+\mathrm{CH}<=>\mathrm{H}+\mathrm{CO}$

$$
\begin{array}{ccc}
(k=A & T^{b} & \exp \\
A & b & -E / R T)
\end{array}
$$

4. $80 \mathrm{E}+16 \quad-1 \quad 5100$

$3.80 \mathrm{E}+14 \quad 0.0 \quad 10000$

$1.45 \mathrm{E}+15 \quad 0.0 \quad 0.0$

$2.17 \mathrm{E}+10 \quad 0.5 \quad 2057.0$

$5.92 \mathrm{E}+12 \quad 0.5 \quad-861.0$

$\begin{array}{lll}2.75 \mathrm{E}+12 & 0.5 & -968.0\end{array}$

$\begin{array}{lll}3.23 \mathrm{E}+12 & 0.5 & -787.0\end{array}$

$\begin{array}{lll}1.50 \mathrm{E}+12 & 0.5 & 0.0\end{array}$

$2.95 \mathrm{E}+12 \quad 0.5 \quad-444.0$

$2.10 \mathrm{E}+12 \quad 0.5 \quad-482.0$

$\begin{array}{lll}1.50 \mathrm{E}+12 & 0.5 & 0.0\end{array}$

$\begin{array}{lll}1.50 \mathrm{E}+12 & 0.5 & 0.0\end{array}$

$3.36 \mathrm{E}+12 \quad 0.5 \quad-635.0$

$\begin{array}{lll}1.40 \mathrm{E}+06 & 0.0 & 0.0\end{array}$

6. $20 \mathrm{E}+12 \quad 0.0 \quad 0.0$

$6.00 \mathrm{E}+14 \quad 0.0 \quad 6940.0$

$1.11 \mathrm{E}+13 \quad 0.0 \quad 0 . \odot$

$2.17 \mathrm{E}+10 \quad 0.0 \quad 0.0$

$\begin{array}{lll}4.00 \mathrm{E}+11 & 0.5 & 0.0\end{array}$

$5.30 \mathrm{E}+13 \quad 0.0 \quad 0.0$

$2.44 \mathrm{E}+12 \quad 0.5 \quad 0.0$

$2.41 \mathrm{E}-01 \quad 4.3 \quad-1694.0$

$2.48 \mathrm{E}+06 \quad 2.1 \quad-1720.0$

$1.47 \mathrm{E}+14 \quad 0.0 \quad 1361.0$

$1.73 \mathrm{E}+13 \quad 0.0 \quad 167.0$

$1.86 \mathrm{E}+06 \quad 0.0 \quad 0.0$

$4.00 \mathrm{E}+05 \quad 2.4 \quad 1000.0$

$\begin{array}{lll}5.0 \odot \mathrm{E}+12 & 0.0 & 0 . \odot\end{array}$

3. $00 \mathrm{E}+14 \quad 0.0 \quad-1000.0$

$5.00 \mathrm{E}+13 \quad 0.0 \quad 0.0$

$\begin{array}{lll}5.00 \mathrm{E}+13 & 0.0 & 0.0\end{array}$

$9.00 \mathrm{E}+12 \quad 0.0 \quad 980.0$

$2.65 \mathrm{E}+16 \quad-0.7 \quad 17041.0$

$3.56 \mathrm{E}+13 \quad 0.0 \quad 30480.0$

$6.84 \mathrm{E}+12 \quad 0.1 \quad 10600.0$

$3.87 \mathrm{E}+04 \quad 2.7 \quad 6260.0$

$\begin{array}{lll}5.00 \mathrm{E}+17 & -1.0 & 0.0\end{array}$
Enhanced by Enhanced by Enhanced by Enhanced by Enhanced by Enhanced by Enhanced by Enhanced by Enhanced by Enhanced by Enhanced by Enhanced by Enhanced by
Enhanced by
2. $000 \mathrm{E}+\odot \odot$

$6.000 \mathrm{E}+\odot \odot$

2. $. \odot \odot E+\odot \odot$

1. $500 \mathrm{E}+\odot \odot$

3. $\odot \odot \odot E+\odot \odot$

7. . ०००E- $\odot 1$

2. $400 \mathrm{E}+00$

1. $540 \mathrm{E}+01$

2. $.00 \mathrm{E}+\odot \odot$

1. $750 \mathrm{E}+00$

3. $600 \mathrm{E}+\odot \odot$

3. $000 \mathrm{E}+00$

8. 30०E- 01
2. $. \odot \odot E+\odot \odot$ $\begin{array}{lll}1.20 \mathrm{E}+17 & -1.0 & 0.0\end{array}$

$\begin{array}{rrr}2.00 \mathrm{E}+13 & 0 . \odot & \odot . \odot \\ 9.63 \mathrm{E}+06 & 2 . \odot & 400 \odot . \odot \\ 5.70 \mathrm{E}+13 & 0.0 & 0 . \odot\end{array}$


42. $\mathrm{O}+\mathrm{CH} 2<=>\mathrm{H}+\mathrm{HCO}$

43. $\mathrm{O}+\mathrm{CH} 2(\mathrm{~S})<=>\mathrm{H} 2+\mathrm{CO}$

44. $\mathrm{O}+\mathrm{CH} 2(\mathrm{~S})<=>\mathrm{H}+\mathrm{HCO}$

45. $\mathrm{O}+\mathrm{CH} 3<=>\mathrm{H}+\mathrm{CH} 2 \mathrm{O}$

46. $\mathrm{O}+\mathrm{CH} 4<=>\mathrm{OH}+\mathrm{CH} 3$

47. $0+\mathrm{CO}(+\mathrm{M})<=>\mathrm{CO} 2(+\mathrm{M})$

Low pressure limit: $0.60200 \mathrm{E}+15 \quad 0.00000 \mathrm{E}+\odot \odot$

$\mathrm{H} 2$

02

$\mathrm{H} 2 \mathrm{O}$

$\mathrm{CH} 4$

$\mathrm{CO}$

$\mathrm{CO} 2$

$\mathrm{C} 2 \mathrm{H} 6$

AR

48. $\mathrm{O}+\mathrm{HCO}<=>\mathrm{OH}+\mathrm{CO}$

49. $\mathrm{O}+\mathrm{HCO}<=>\mathrm{H}+\mathrm{CO} 2$

50. $\mathrm{O}+\mathrm{CH} 2 \mathrm{O}<=>\mathrm{OH}+\mathrm{HCO}$

51. $\mathrm{O}+\mathrm{CH} 2 \mathrm{OH}<=>\mathrm{OH}+\mathrm{CH} 2 \mathrm{O}$

52. $\mathrm{O}+\mathrm{CH} 3 \mathrm{O}<=>\mathrm{OH}+\mathrm{CH} 2 \mathrm{O}$

53. $\mathrm{O}+\mathrm{CH} 3 \mathrm{OH}<=>\mathrm{OH}+\mathrm{CH} 2 \mathrm{OH}$

54. $\mathrm{O}+\mathrm{CH} 3 \mathrm{OH}<=>\mathrm{OH}+\mathrm{CH} 3 \mathrm{O}$

55. $\mathrm{O}+\mathrm{C} 2 \mathrm{H}<=>\mathrm{CH}+\mathrm{CO}$

56. $\mathrm{O}+\mathrm{C} 2 \mathrm{H} 2<=>\mathrm{H}+\mathrm{HCCO}$

57. $\mathrm{O}+\mathrm{C} 2 \mathrm{H} 2<=>\mathrm{OH}+\mathrm{C} 2 \mathrm{H}$

58. $\mathrm{O}+\mathrm{C} 2 \mathrm{H} 2<=>\mathrm{CO}+\mathrm{CH} 2$

59. $\mathrm{O}+\mathrm{C} 2 \mathrm{H} 3<=>\mathrm{H}+\mathrm{CH} 2 \mathrm{CO}$

60. $0+\mathrm{C} 2 \mathrm{H} 4<=>\mathrm{CH} 3+\mathrm{HCO}$

61. $\mathrm{O}+\mathrm{C} 2 \mathrm{H} 5<=>\mathrm{CH} 3+\mathrm{CH} 2 \mathrm{O}$

62. $\mathrm{O}+\mathrm{C} 2 \mathrm{H} 6<=>\mathrm{OH}+\mathrm{C} 2 \mathrm{H} 5$

63. $0+\mathrm{HCCO}<=>\mathrm{H}+2 \mathrm{CO}$

64. $\mathrm{O}+\mathrm{CH} 2 \mathrm{CO}<=>\mathrm{OH}+\mathrm{HCCO}$

65. $\mathrm{O}+\mathrm{CH} 2 \mathrm{CO}<=>\mathrm{CH} 2+\mathrm{CO} 2$

66. $02+\mathrm{CO}<=>0+\mathrm{CO} 2$

67. $02+\mathrm{CH} 2 \mathrm{O}<=>\mathrm{HO} 2+\mathrm{HCO}$

68. $\mathrm{H}+\mathrm{O} 2+\mathrm{M}<=>\mathrm{HO} 2+\mathrm{M}$

02

$\mathrm{H} 20$

$\mathrm{CO}$

$\mathrm{CO} 2$

$\mathrm{C} 2 \mathrm{H} 6$

AR

69. $\mathrm{H}+2 \mathrm{O} 2<=>\mathrm{HO} 2+02$

70. $\mathrm{H}+\mathrm{O} 2+\mathrm{H} 2 \mathrm{O}<=>\mathrm{HO} 2+\mathrm{H} 2 \mathrm{O}$

71. $\mathrm{H}+02+\mathrm{AR}<=>\mathrm{HO} 2+\mathrm{AR}$

72. $2 \mathrm{H}+\mathrm{M}<=>\mathrm{H} 2+\mathrm{M}$

$\begin{array}{ll}\mathrm{H} 2 & \text { Enhanced by } \\ \mathrm{H} 2 \mathrm{O} & \text { Enhanced by } \\ \mathrm{CH} 4 & \text { Enhanced by } \\ \mathrm{CO} 2 & \text { Enhanced by } \\ \mathrm{C} 2 \mathrm{H} 6 & \text { Enhanced by } \\ \mathrm{AR} & \text { Enhanced by }\end{array}$

73. $2 \mathrm{H}+\mathrm{H} 2<=>2 \mathrm{H} 2$

74. $2 \mathrm{H}+\mathrm{H} 2 \mathrm{O}<=>\mathrm{H} 2+\mathrm{H} 2 \mathrm{O}$

75. $2 \mathrm{H}+\mathrm{CO} 2<=>\mathrm{H} 2+\mathrm{CO} 2$

76. $\mathrm{H}+\mathrm{OH}+\mathrm{M}<=>\mathrm{H} 2 \mathrm{O}+\mathrm{M}$

$\mathrm{H} 2$

$\mathrm{H} 2 \mathrm{O}$

$\mathrm{CH} 4$

$\mathrm{C} 2 \mathrm{H} 6$

AR

Enhanced by

Enhanced by

Enhanced by

Enhanced by

Enhanced by
Enhanced by $2.000 \mathrm{E}+\odot \odot$

Enhanced by $6.0 \odot \odot \mathrm{E}+\odot \odot$

Enhanced by 2.000E+००

Enhanced by $1.500 \mathrm{E}+\odot \odot$

Enhanced by $3.500 \mathrm{E}+00$

Enhanced by 3.000E+००

Enhanced by 5.000E-01
Enhanced by $6.000 \mathrm{E}+\odot \odot$

$\begin{array}{rrr}8.00 \mathrm{E}+13 & 0 . \odot & 0 . \odot \\ 1.50 \mathrm{E}+13 & 0 . \odot & 0 . \odot \\ 1.50 \mathrm{E}+13 & 0 . \odot & 0 . \odot \\ 5.06 \mathrm{E}+13 & 0 . \odot & 0 . \odot \\ 1.02 \mathrm{E}+09 & 1.5 & 8600 . \odot \\ 1.80 \mathrm{E}+10 & 0 . \odot & 2385 . \odot\end{array}$

3. $00 \mathrm{E}+13$

3. $\odot \odot E+13$

$\odot . \odot$

0.0

$\odot .0$

$\odot .0$

1. $0 \odot \mathrm{E}+13$

1. $\odot \odot E+13$

3. $88 \mathrm{E}+05$

1. $30 \mathrm{E}+05$

5. $00 \mathrm{E}+13$

1. $35 \mathrm{E}+07$

4. $60 \mathrm{E}+19$

6. $94 \mathrm{E}+06$

3. $00 \mathrm{E}+13$

1. $25 \mathrm{E}+07$

2. $24 \mathrm{E}+13$

8. $98 \mathrm{E}+07$

1. $0 \odot \mathrm{E}+14$

1. $00 \mathrm{E}+13$

1. $75 \mathrm{E}+12$

2. $50 \mathrm{E}+12$

1. $00 \mathrm{E}+14$

2. $80 \mathrm{E}+18$

$\odot . \odot \odot \odot E+\odot \odot$

$\odot ., \odot \odot \odot E+\odot \odot$

7. 50०E- $\odot 1$

1. $500 \mathrm{E}+00$

1. $500 \mathrm{E}+\odot \odot$

$\odot . \odot \odot \odot E+\odot \odot$

$\begin{array}{lll}2.08 E+19 & -1.2 & 0 . \odot \\ 1.13 E+19 & -0.8 & 0.0 \\ 7.00 E+17 & -0.8 & 0.0 \\ 1.00 E+18 & -1.0 & 0.0\end{array}$

$\odot . ~ . \odot \odot E+\odot \odot$

$\odot .00 \odot \mathrm{E}+\odot \odot$

$2.000 \mathrm{E}+00$

$\odot . \odot \odot \odot E+\odot \odot$

3. $.00 \mathrm{E}+0 \odot$

6. 30०E- 01

7. 300E- 01

3. $650 \mathrm{E}+0 \odot$

2. $00 \odot \mathrm{E}+\Theta \odot$

3. $\odot \odot \odot E+\odot \odot$

3. $800 \mathrm{E}-\odot 1$

$\begin{array}{lll}9.00 \mathrm{E}+16 & -0.6 & 0 . \odot \\ 6.00 \mathrm{E}+19 & -1.3 & 0.0 \\ 5.50 \mathrm{E}+20 & -2.0 & 0.0 \\ 2.20 \mathrm{E}+22 & -2.0 & 0.0\end{array}$




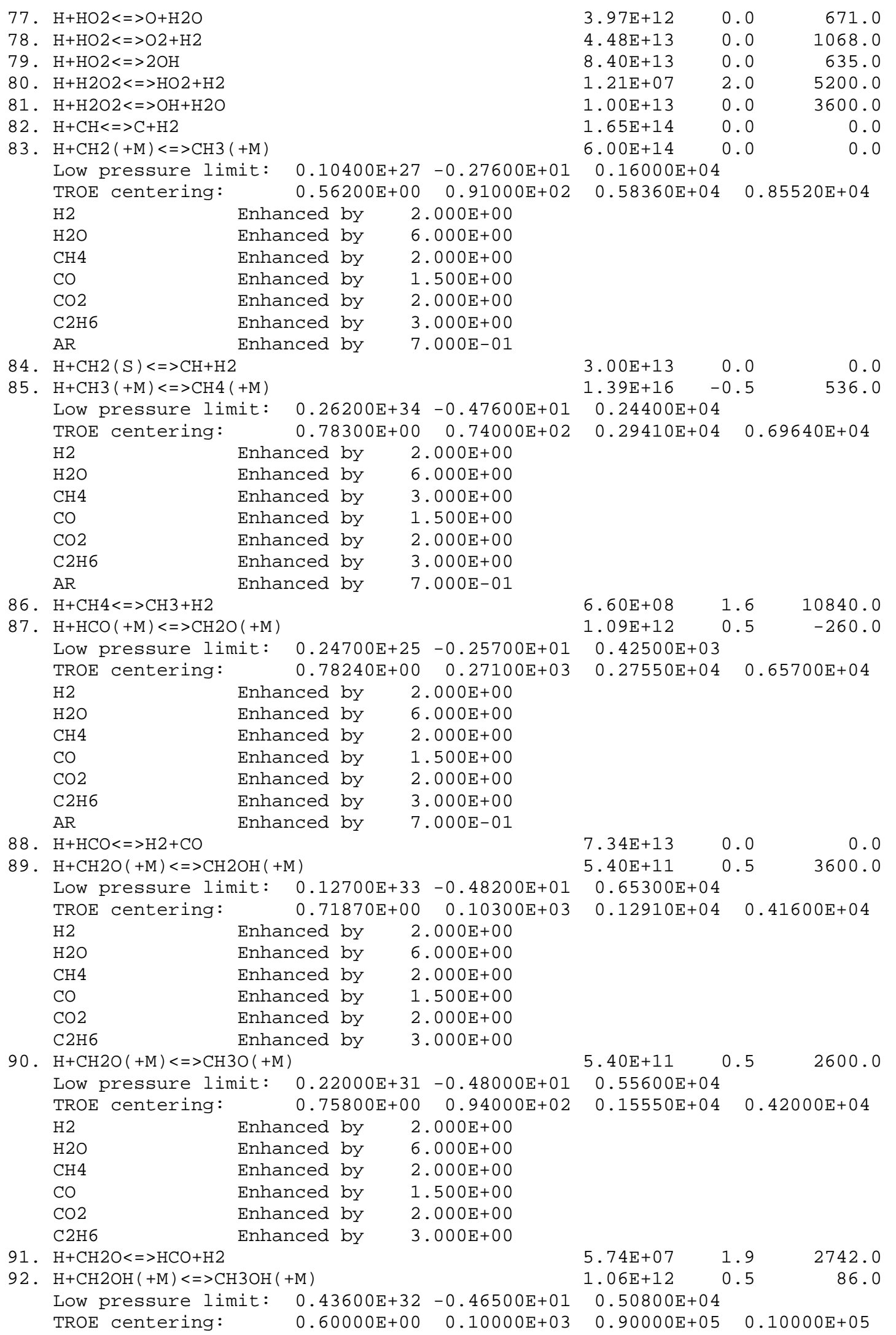




$\begin{array}{lll}\mathrm{H} 2 & \text { Enhanced by } & 2.0 \odot \odot \mathrm{E}+\odot \odot \\ \mathrm{H} 20 & \text { Enhanced by } & 6.0 \odot \odot \mathrm{E}+\odot \odot \\ \mathrm{CH} 4 & \text { Enhanced by } & 2.00 \odot \mathrm{E}+\odot \odot \\ \mathrm{CO} & \text { Enhanced by } & 1.50 \odot \mathrm{E}+\odot \odot \\ \mathrm{C} 2 & \text { Enhanced by } & 2.0 \odot \odot \mathrm{E}+\odot \odot \\ \mathrm{C} 2 \mathrm{H} 6 & \text { Enhanced by } & 3.0 \odot \odot \mathrm{E}+\odot \odot\end{array}$

93. $\mathrm{H}+\mathrm{CH} 2 \mathrm{OH}<=>\mathrm{H} 2+\mathrm{CH} 2 \mathrm{O}$

94. $\mathrm{H}+\mathrm{CH} 2 \mathrm{OH}<=>\mathrm{OH}+\mathrm{CH} 3$

95. $\mathrm{H}+\mathrm{CH} 2 \mathrm{OH}<=>\mathrm{CH} 2(\mathrm{~S})+\mathrm{H} 2 \mathrm{O}$

96. $\mathrm{H}+\mathrm{CH} 3 \mathrm{O}(+\mathrm{M})<=>\mathrm{CH} 3 \mathrm{OH}(+\mathrm{M})$

$\begin{array}{rrr}2.00 \mathrm{E}+13 & 0 . \odot & 0 . \odot \\ 1.65 \mathrm{E}+11 & 0.7 & -284.0 \\ 3.28 \mathrm{E}+13 & -0.1 & 610.0 \\ 2.43 \mathrm{E}+12 & 0.5 & 50.0\end{array}$

Low pressure limit: $\quad 0.46600 \mathrm{E}+42-0.74400 \mathrm{E}+01 \quad 0.14080 \mathrm{E}+05$

TROE centering: $\quad 0.70000 \mathrm{E}+\odot \odot \quad \odot .1000 \odot \mathrm{E}+\odot 3$

$0.90000 \mathrm{E}+05$

$\odot .10 \odot \odot \odot E+\odot 5$

$\mathrm{H} 2$

$\mathrm{H} 20$

$\mathrm{CH} 4$

$\mathrm{CO}$

$\mathrm{CO} 2$

$\mathrm{C} 2 \mathrm{H} 6$
Enhanced by

Enhanced by

Enhanced by

Enhanced by

Enhanced by

Enhanced by
$2.0 \odot \odot \mathrm{E}+\odot \odot$

6. $\odot \odot \odot \mathrm{E}+\odot \odot$

2. $\odot \odot \odot E+\odot \odot$

1. $500 \mathrm{E}+\odot \odot$

2. $\odot \odot \odot E+\odot \odot$

3. $.0 \odot \mathrm{E}+\odot \odot$

97. $\mathrm{H}+\mathrm{CH} 3 \mathrm{O}<=>\mathrm{H}+\mathrm{CH} 2 \mathrm{OH}$

98. $\mathrm{H}+\mathrm{CH} 3 \mathrm{O}<=>\mathrm{H} 2+\mathrm{CH} 2 \mathrm{O}$

99. $\mathrm{H}+\mathrm{CH} 30<=>\mathrm{OH}+\mathrm{CH} 3$

100. $\mathrm{H}+\mathrm{CH} 30<=>\mathrm{CH} 2(\mathrm{~S})+\mathrm{H} 2 \mathrm{O}$

101. $\mathrm{H}+\mathrm{CH} 3 \mathrm{OH}<=>\mathrm{CH} 2 \mathrm{OH}+\mathrm{H} 2$

102. $\mathrm{H}+\mathrm{CH} 3 \mathrm{OH}<=>\mathrm{CH} 30+\mathrm{H} 2$

103. $\mathrm{H}+\mathrm{C} 2 \mathrm{H}(+\mathrm{M})<=>\mathrm{C} 2 \mathrm{H} 2(+\mathrm{M})$

Low pressure limit:

TROE centering:

$\mathrm{H} 2$

$\mathrm{H} 20$

\section{Ent} Enhanced by

$\odot .37500 E+34-\odot .48000 E+01$

$\begin{array}{rrr}4.15 \mathrm{E}+\Theta 7 & 1.6 & 1924 . \odot \\ 2.0 \odot \mathrm{E}+13 & 0 . \odot & 0 . \odot \\ 1.50 \mathrm{E}+12 & 0.5 & -110 . \odot \\ 2.62 \mathrm{E}+14 & -0.2 & 1070 . \odot \\ 1.70 \mathrm{E}+07 & 2.1 & 4870 . \odot \\ 4.20 \mathrm{E}+06 & 2.1 & 4870.0 \\ 1.00 \mathrm{E}+17 & -1 . \odot & 0 . \odot\end{array}$

$\mathrm{CH} 4$

Enhanced by

$0.13200 \mathrm{E}+03$

$\odot .19000 \mathrm{E}+04$

$\odot .13150 \mathrm{E}+04$

$\odot .55660 \mathrm{E}+\odot 4$

$\mathrm{CO}$

Enhanced by

2. $0 \odot \odot \mathrm{E}+\odot \odot$

Enhanced by

6. $\odot \odot \odot \mathrm{E}+\odot \odot$

2. $000 \mathrm{E}+00$

$\mathrm{CO} 2$

Enhanced by

1. $500 \mathrm{E}+\odot \odot$

$\mathrm{C} 2 \mathrm{H} 6$

Enhanced by

2. $000 \mathrm{E}+\odot \odot$

3. $\odot \odot \odot E+\odot \odot$

AR

Enhanced by 7.00०E-०1

104. $\mathrm{H}+\mathrm{C} 2 \mathrm{H} 2(+\mathrm{M})<=>\mathrm{C} 2 \mathrm{H} 3(+\mathrm{M})$

Low pressure limit: $0.38000 \mathrm{E}+41-0.72700 \mathrm{E}+01$

$5.60 \mathrm{E}+12 \quad 0.0 \quad 2400.0$

TROE centering:

$\mathrm{H} 2$ $\odot .75070 \mathrm{E}+\odot \odot \quad 0.98500 \mathrm{E}+\odot 2$

$\mathrm{H} 20$

Enhanced by

2. $.000 \mathrm{E}+0 \odot$

$\mathrm{CH} 4$

Enhanced by

6. $\odot \odot \odot \mathrm{E}+\odot \odot$

$\mathrm{CO}$

Enhanced by

2. $.00 \mathrm{E}+\odot \odot$

Enhanced by

1. $500 \mathrm{E}+\odot \odot$

$\mathrm{CO} 2$

Enhanced by

2. $000 \mathrm{E}+\odot \odot$

$\mathrm{C} 2 \mathrm{H} 6$

Enhanced by

3. $000 \mathrm{E}+\odot \odot$

AR

Enhanced by

7. $.00 \mathrm{E}-01$

105. $\mathrm{H}+\mathrm{C} 2 \mathrm{H} 3(+\mathrm{M})<=>\mathrm{C} 2 \mathrm{H} 4(+\mathrm{M})$

Low pressure limit: $\quad 0.14000 \mathrm{E}+31-\odot .38600 \mathrm{E}+01$

TROE centering:

$\mathrm{H} 2$

$\mathrm{H} 20$

$\mathrm{CH} 4$

$\mathrm{CO}$

$\mathrm{CO} 2$

$\mathrm{C} 2 \mathrm{H} 6$

AR

106. $\mathrm{H}+\mathrm{C} 2 \mathrm{H} 3<=>\mathrm{H}_{2}+\mathrm{C} 2 \mathrm{H} 2$

$\begin{array}{ll}\text { Enhanced by } & 2.00 \odot \mathrm{E}+\odot \odot \\ \text { Enhanced by } & 6.00 \odot \mathrm{E}+\odot \odot \\ \text { Enhanced by } & 2.00 \odot \mathrm{E}+\odot \odot \\ \text { Enhanced by } & 1.500 \mathrm{E}+\odot \odot \\ \text { Enhanced by } & 2.00 \odot \mathrm{E}+\odot \odot \\ \text { Enhanced by } & 3.00 \odot \mathrm{E}+\odot \odot \\ \text { Enhanced by } & 7.0 \odot \odot \mathrm{E}-\odot 1\end{array}$

$6.08 \mathrm{E}+12 \quad 0.3 \quad 280.0$

$0.33200 \mathrm{E}+04$

$\odot .26630 \mathrm{E}+\odot 4 \quad \odot .60950 \mathrm{E}+\odot 4$

107. $\mathrm{H}+\mathrm{C} 2 \mathrm{H} 4(+\mathrm{M})<=>\mathrm{C} 2 \mathrm{H} 5(+\mathrm{M})$

Low pressure limit: $0.60000 \mathrm{E}+42-0.76200 \mathrm{E}+01$

$\begin{array}{lll}3.00 \mathrm{E}+13 & 0.0 & 0.0\end{array}$

TROE centering:

$\mathrm{H} 2$

$\odot .97530 \mathrm{E}+0 \odot \quad 0.21000 \mathrm{E}+03$

5. $40 \mathrm{E}+11$

$\odot .5$

1820.0

$\mathrm{H} 2 \mathrm{O}$

Enhanced by

2. $\odot \odot \odot E+\odot \odot$

$\mathrm{CH} 4$

Enhanced by

6. $. \odot \odot \mathrm{E}+\odot \odot$

Enhanced by

2. $\odot \odot \odot E+\odot \odot$

$\odot .69700 \mathrm{E}+04$

$\odot .98400 \mathrm{E}+03 \quad \odot .43740 \mathrm{E}+\odot 4$ 


\begin{tabular}{|c|c|c|c|c|c|c|}
\hline & $\mathrm{CO}$ & Enhanced by & 1. 500E+०० & & & \\
\hline & $\mathrm{CO} 2$ & Enhanced by & 2. $\odot \odot \odot E+\odot \odot$ & & & \\
\hline & $\mathrm{C} 2 \mathrm{H} 6$ & Enhanced by & 3. $\odot \odot \odot E+\odot \odot$ & & & \\
\hline & AR & Enhanced by & 7. $. \odot \odot E-\odot 1$ & & & \\
\hline 108. & \multicolumn{3}{|c|}{$\mathrm{H}+\mathrm{C} 2 \mathrm{H} 4<=>\mathrm{C} 2 \mathrm{H} 3+\mathrm{H} 2$} & $1.33 E+06$ & 2.5 & 12240.0 \\
\hline \multirow[t]{10}{*}{109.} & \multicolumn{3}{|c|}{$\mathrm{H}+\mathrm{C} 2 \mathrm{H} 5(+\mathrm{M})<=>\mathrm{C} 2 \mathrm{H} 6(+\mathrm{M})$} & $5.21 E+17 \quad-$ & -1.0 & 1580.0 \\
\hline & \multicolumn{3}{|c|}{ Low pressure limit: $\quad 0.19900 \mathrm{E}+42$} & \multicolumn{3}{|c|}{$\odot .66850 \mathrm{E}+04$} \\
\hline & \multicolumn{2}{|c|}{ TROE centering: $\quad \odot .84220 \mathrm{E}+\odot \odot$} & $\odot \quad \odot .1250 \odot \mathrm{E}+\odot 3$ & $\odot .22190 \mathrm{E}+\odot 4$ & & ๑. $68820 \mathrm{E}+\odot 4$ \\
\hline & & & \multicolumn{4}{|l|}{$2.0 \odot \odot E+\odot \odot$} \\
\hline & $\mathrm{H} 2 \mathrm{O}$ & Enhanced by & $6 . \odot \odot \odot E+\odot \odot$ & & & \\
\hline & $\mathrm{CH} 4$ & Enhanced by & 2. . ०००E+०० & & & \\
\hline & $\mathrm{CO}$ & Enhanced by & 1. 5००E+०० & & & \\
\hline & C02 & Enhanced by & 2. $\odot \odot \odot E+\odot \odot$ & & & \\
\hline & $\mathrm{C} 2 \mathrm{H} 6$ & Enhanced by & 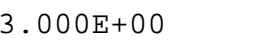 & & & \\
\hline & AR & Enhanced by & 7. $000 \mathrm{E}-01$ & & & \\
\hline 110 & \multicolumn{3}{|c|}{$\mathrm{H}+\mathrm{C} 2 \mathrm{H} 5<=>\mathrm{H} 2+\mathrm{C} 2 \mathrm{H} 4$} & $2.00 \mathrm{E}+12$ & $\odot . \odot$ & 0.0 \\
\hline 111. & \multicolumn{3}{|l|}{$\mathrm{H}+\mathrm{C} 2 \mathrm{H} 6<=>\mathrm{C} 2 \mathrm{H} 5+\mathrm{H} 2$} & $1.15 \mathrm{E}+08$ & 1.9 & 7530.0 \\
\hline 112. & \multicolumn{3}{|l|}{$\mathrm{H}+\mathrm{HCCO}<=>\mathrm{CH} 2(\mathrm{~S})+\mathrm{CO}$} & 1. $.0 \mathrm{E}+14$ & $\odot . \odot$ & 0.0 \\
\hline 113. & \multicolumn{3}{|l|}{$\mathrm{H}+\mathrm{CH} 2 \mathrm{CO}<=>\mathrm{HCCO}+\mathrm{H} 2$} & 5. $0 \odot E+13$ & $\odot . \odot$ & 8000.0 \\
\hline 114. & \multicolumn{3}{|l|}{$\mathrm{H}+\mathrm{CH} 2 \mathrm{CO}<=>\mathrm{CH} 3+\mathrm{CO}$} & $1 \cdot 13 E+13$ & $\odot . \odot$ & 3428.0 \\
\hline 115. & \multicolumn{3}{|c|}{$\mathrm{H}+\mathrm{HCCOH}<=>\mathrm{H}+\mathrm{CH} 2 \mathrm{CO}$} & 1. $0 \odot \mathrm{E}+13$ & $\odot . \odot$ & 0.0 \\
\hline \multirow[t]{10}{*}{116.} & \multicolumn{3}{|c|}{$\mathrm{H} 2+\mathrm{CO}(+\mathrm{M})<=>\mathrm{CH} 2 \mathrm{O}(+\mathrm{M})$} & $4.30 \mathrm{E}+07$ & 1.5 & 79600.0 \\
\hline & \multicolumn{3}{|c|}{ Low pressure limit: } & $\odot .84350 \mathrm{E}+05$ & & \\
\hline & TROE centering: & $0.93200 \mathrm{E}+0 \odot$ & $\odot \quad \odot .19700 \mathrm{E}+\odot 3$ & $\odot .15400 \mathrm{E}+\odot 4$ & & ๑. $10300 \mathrm{E}+05$ \\
\hline & $\mathrm{H} 2$ & Enhanced by 2 & 2. $.0 \odot \mathrm{E}+\odot \odot$ & & & \\
\hline & $\mathrm{H} 2 \mathrm{O}$ & Enhanced by & 6. $\odot \odot \odot E+\odot \odot$ & & & \\
\hline & $\mathrm{CH} 4$ & Enhanced by & 2. ๑९७E +๑९ & & & \\
\hline & $\mathrm{CO}$ & Enhanced by & 1. $500 \mathrm{E}+00$ & & & \\
\hline & $\mathrm{CO} 2$ & Enhanced by & $2.0 \odot \odot E+\odot \odot$ & & & \\
\hline & $\mathrm{C} 2 \mathrm{H} 6$ & Enhanced by & 3. $\odot \odot \odot E+\odot \odot$ & & & \\
\hline & AR & Enhanced by & 7. $0 \odot \odot E-\odot 1$ & & & \\
\hline 117. & $\mathrm{OH}+\mathrm{H} 2<=>\mathrm{H}+\mathrm{H} 2 \mathrm{O}$ & & & $2.16 \mathrm{E}+08$ & 1.5 & 3430.0 \\
\hline 118. & $2 \mathrm{OH}(+\mathrm{M})<=>\mathrm{H} 2 \mathrm{O} 2(+$ & $-M)$ & & $7.40 \mathrm{E}+13$ & -0.4 & 0.0 \\
\hline & Low pressure lim & $0.23000 \mathrm{E}+19$ & $9-\odot .900 \odot \odot E+\odot \odot$ & $-0.17000 \mathrm{E}+04$ & & \\
\hline & TROE centering: & $\odot .73460 \mathrm{E}+\odot \odot$ & $\odot \quad \odot .94000 \mathrm{E}+\odot 2$ & $\odot .17560 \mathrm{E}+\odot 4$ & & ๑. 51820E+๑4 \\
\hline & $\mathrm{H} 2$ & Enhanced by 2 & 2. $.0 \odot E+\odot \odot$ & & & \\
\hline & $\mathrm{H} 2 \mathrm{O}$ & Enhanced by & 6. $\odot \odot \odot E+\odot \odot$ & & & \\
\hline & $\mathrm{CH} 4$ & Enhanced by & 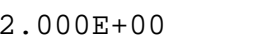 & & & \\
\hline & $\mathrm{CO}$ & Enhanced by & 1. $500 \mathrm{E}+\odot \odot$ & & & \\
\hline & $\mathrm{CO} 2$ & Enhanced by & 2. $\odot \odot \odot E+\odot \odot$ & & & \\
\hline & $\mathrm{C} 2 \mathrm{H} 6$ & Enhanced by & 3. $\odot \odot \odot E+\odot \odot$ & & & \\
\hline & AR & Enhanced by & 7. $. \odot \odot E-\odot 1$ & & & \\
\hline 119. & $2 \mathrm{OH}<=>0+\mathrm{H} 2 \mathrm{O}$ & & & $3.57 E+\odot 4$ & 2.4 & -2110.0 \\
\hline 120. & $\begin{array}{l}\mathrm{OH}+\mathrm{HO} 2<=>02+\mathrm{H} 20 \\
\text { Declared duplica }\end{array}$ & ate reaction... & & 1. $45 \mathrm{E}+13$ & $\odot . \odot$ & -500.0 \\
\hline 121. & $\begin{array}{l}\mathrm{OH}+\mathrm{H} 2 \mathrm{O} 2<=>\mathrm{HO} 2+\mathrm{H} 2 \\
\text { Declared duplica }\end{array}$ & ate reaction... & & $2.00 \mathrm{E}+12$ & $\odot . \odot$ & 427.0 \\
\hline 122. & $\begin{array}{l}\mathrm{OH}+\mathrm{H} 2 \mathrm{O} 2<=>\mathrm{HO} 2+\mathrm{H} 2 \\
\text { Declared duplica }\end{array}$ & ate reaction... & & 1. $70 \mathrm{E}+18$ & $\odot . \odot$ & 29410.0 \\
\hline 123. & $\mathrm{OH}+\mathrm{C}<=>\mathrm{H}+\mathrm{CO}$ & & & 5. $.0 E+13$ & $\odot . \odot$ & $\odot . \odot$ \\
\hline 124. & $\mathrm{OH}+\mathrm{CH}<=>\mathrm{H}+\mathrm{HCO}$ & & & 3. $00 \mathrm{E}+13$ & $\odot . \odot$ & $\odot . \odot$ \\
\hline 125. & $\mathrm{OH}+\mathrm{CH} 2<=>\mathrm{H}+\mathrm{CH} 2 \mathrm{O}$ & & & $2.0 \odot E+13$ & $\odot .0$ & 0.0 \\
\hline 126. & $\mathrm{OH}+\mathrm{CH} 2<=>\mathrm{CH}+\mathrm{H} 2 \mathrm{O}$ & & & 1. $13 E+07$ & 2.0 & 3000.0 \\
\hline 127. & $\mathrm{OH}+\mathrm{CH} 2(\mathrm{~S})<=>\mathrm{H}+\mathrm{CH}$ & +20 & & $3.00 \mathrm{E}+13$ & 0.0 & 0.0 \\
\hline 128. & $\mathrm{OH}+\mathrm{CH} 3(+\mathrm{M})<=>\mathrm{CH} 3$ & $30 \mathrm{H}(+\mathrm{M})$ & & $2.79 \mathrm{E}+18$ & -1.4 & 1330.0 \\
\hline & Low pressure lim & nit: $\quad 0.4000 \odot E+37$ & $-\odot .5920 \odot E+\odot 1$ & $0.31400 \mathrm{E}+04$ & & \\
\hline & TROE centering: & $\odot .4120 \odot \mathrm{E}+\odot \odot$ & $\odot \quad \odot .19500 \mathrm{E}+\odot 3$ & $\odot .59000 \mathrm{E}+\odot 4$ & & ๑. $63940 \mathrm{E}+04$ \\
\hline & $\mathrm{H} 2$ & Enhanced by 2 & 2. $.0 \odot E+\odot \odot$ & & & \\
\hline & $\mathrm{H} 2 \mathrm{O}$ & Enhanced by & 6. $00 \odot E+0 \odot$ & & & \\
\hline & $\mathrm{CH} 4$ & Enhanced by & 2. $\odot \odot \odot E+\odot \odot$ & & & \\
\hline & $\mathrm{CO}$ & Enhanced by & 1. $500 \mathrm{E}+\odot \odot$ & & & \\
\hline
\end{tabular}




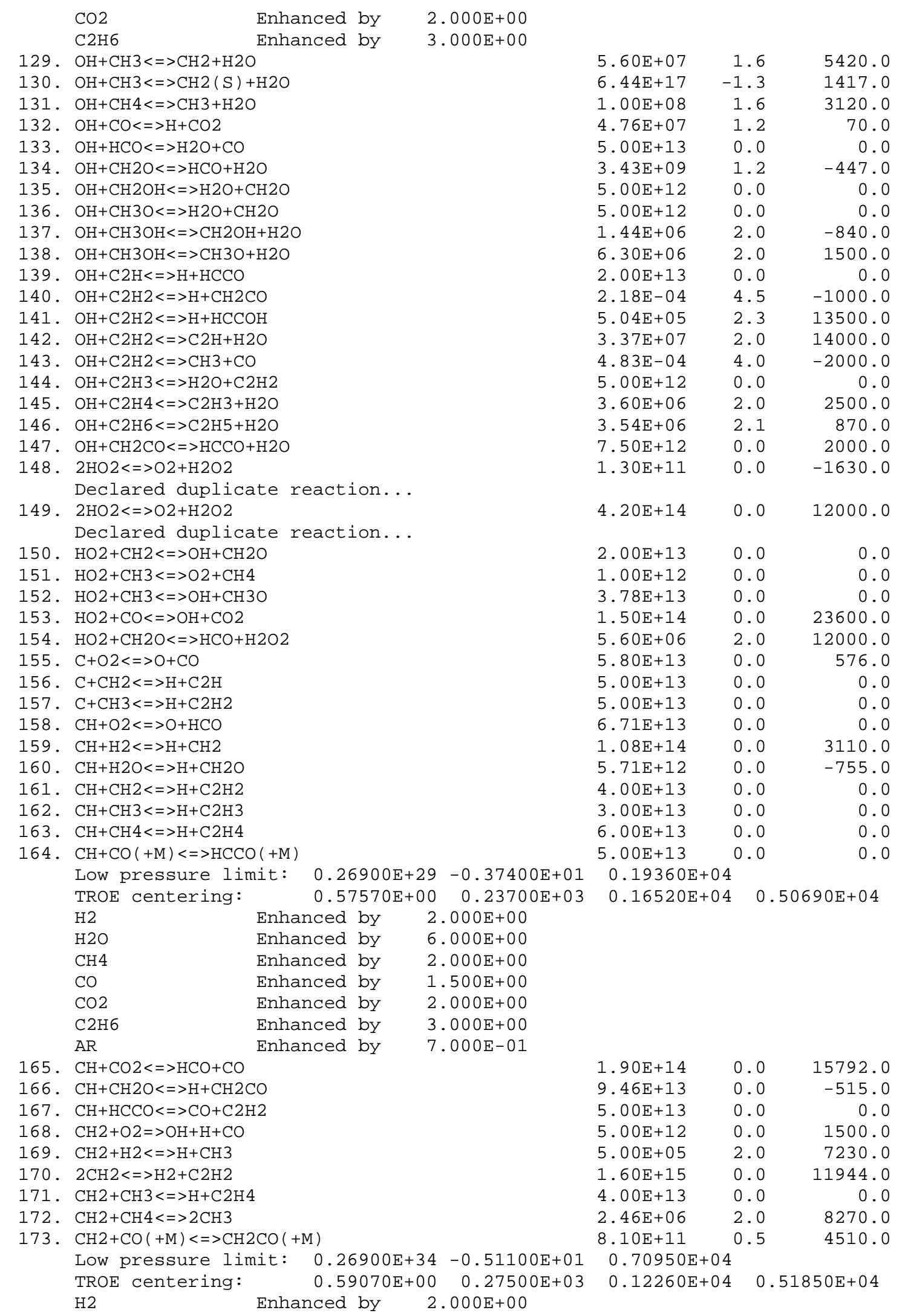




\begin{tabular}{|c|c|c|c|c|c|c|}
\hline & $\mathrm{H} 2 \mathrm{O}$ & Enhanced by & $6 . \odot \odot \odot E+\odot \odot$ & & & \\
\hline & $\mathrm{CH} 4$ & Enhanced by & $2.000 E+0 \odot$ & & & \\
\hline & $\mathrm{CO}$ & Enhanced by & $1.500 \mathrm{E}+00$ & & & \\
\hline & C02 & Enhanced by & 2. .००E+०० & & & \\
\hline & $\mathrm{C} 2 \mathrm{H} 6$ & Enhanced by & 3. $\odot \odot \odot E+\odot \odot$ & & & \\
\hline & AR & Enhanced by & 7. $\odot \odot \odot E-\odot 1$ & & & \\
\hline 174. & \multicolumn{3}{|c|}{$\mathrm{CH} 2+\mathrm{HCCO}<=>\mathrm{C} 2 \mathrm{H} 3+\mathrm{CO}$} & $3.00 \mathrm{E}+13$ & $\odot . \odot$ & $0 . \odot$ \\
\hline 175. & \multicolumn{3}{|c|}{$\mathrm{CH} 2(\mathrm{~S})+\mathrm{AR}<=>\mathrm{CH} 2+\mathrm{AR}$} & $9.00 \mathrm{E}+12$ & $\odot . \odot$ & 600.0 \\
\hline 176. & \multicolumn{3}{|c|}{$\mathrm{CH} 2(\mathrm{~S})+02<=>\mathrm{H}+\mathrm{OH}+\mathrm{CO}$} & $2.80 E+13$ & $\odot . \odot$ & $0 . \odot$ \\
\hline 177. & \multicolumn{3}{|c|}{$\mathrm{CH} 2(\mathrm{~S})+02<=>\mathrm{CO}+\mathrm{H} 2 \mathrm{O}$} & 1. $20 \mathrm{E}+13$ & $\odot . \odot$ & $\odot . \odot$ \\
\hline 178. & \multicolumn{3}{|c|}{$\mathrm{CH} 2(\mathrm{~S})+\mathrm{H} 2<=>\mathrm{CH} 3+\mathrm{H}$} & $7.00 E+13$ & 0.0 & 0.0 \\
\hline 179. & \multicolumn{3}{|c|}{$\mathrm{CH} 2(\mathrm{~S})+\mathrm{H} 2 \mathrm{O}(+\mathrm{M})<=>\mathrm{CH} 3 \mathrm{OH}(+\mathrm{M})$} & 4. $82 \mathrm{E}+17$ & -1.2 & 1145.0 \\
\hline & \multicolumn{3}{|c|}{ Low pressure limit: $\quad 0.18800 \mathrm{E}+39-\odot .63600 \mathrm{E}+01$} & \multicolumn{3}{|c|}{$\odot .5 \odot 40 \odot E+\odot 4$} \\
\hline & \multicolumn{3}{|c|}{ TROE centering: $\quad 0.60270 \mathrm{E}+\odot \odot \quad \odot .20800 \mathrm{E}+\odot 3$} & \multicolumn{2}{|c|}{$\odot .39220 \mathrm{E}+\odot 4$} & $\odot .10180 E+\odot 5$ \\
\hline & $\mathrm{H} 2$ & Enhanced by & $2.000 E+00$ & & & \\
\hline & $\mathrm{H} 2 \mathrm{O}$ & Enhanced by & 6. $\odot \odot \odot E+\odot \odot$ & & & \\
\hline & $\mathrm{CH} 4$ & Enhanced by & 2. .००० +०० & & & \\
\hline & $\mathrm{CO}$ & Enhanced by & $1.500 \mathrm{E}+00$ & & & \\
\hline & $\mathrm{CO} 2$ & Enhanced by & 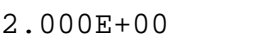 & & & \\
\hline & $\mathrm{C} 2 \mathrm{H} 6$ & Enhanced by & 3. $\odot \odot \odot E+\odot \odot$ & & & \\
\hline 180. & \multicolumn{3}{|c|}{$\mathrm{CH} 2(\mathrm{~S})+\mathrm{H} 2 \mathrm{O}<=>\mathrm{CH} 2+\mathrm{H} 2 \mathrm{O}$} & $3.00 E+13$ & $\odot . \odot$ & 0.0 \\
\hline 181. & \multicolumn{3}{|c|}{$\mathrm{CH} 2(\mathrm{~S})+\mathrm{CH} 3<=>\mathrm{H}+\mathrm{C} 2 \mathrm{H} 4$} & 1. $20 \mathrm{E}+13$ & $\odot . \odot$ & -570.0 \\
\hline 182. & \multicolumn{3}{|c|}{$\mathrm{CH} 2(\mathrm{~S})+\mathrm{CH} 4<=>2 \mathrm{CH} 3$} & $1.60 \mathrm{E}+13$ & $\odot . \odot$ & -570.0 \\
\hline 183. & \multicolumn{3}{|c|}{$\mathrm{CH} 2(\mathrm{~S})+\mathrm{CO}<=>\mathrm{CH} 2+\mathrm{CO}$} & $9.00 \mathrm{E}+12$ & $\odot . \odot$ & 0.0 \\
\hline 184. & $\mathrm{CH} 2(\mathrm{~S})+\mathrm{CO} 2<=>\mathrm{CH}_{2}$ & $2+\mathrm{CO} 2$ & & $7.00 \mathrm{E}+12$ & $\odot . \odot$ & $\odot . \odot$ \\
\hline 185. & $\mathrm{CH} 2(\mathrm{~S})+\mathrm{CO} 2<=>\mathrm{CO}$ & $+\mathrm{CH} 2 \mathrm{O}$ & & 1. $40 E+13$ & $\odot . \odot$ & 0.0 \\
\hline 186. & $\mathrm{CH} 2(\mathrm{~S})+\mathrm{C} 2 \mathrm{H} 6<=>\mathrm{Cl}$ & $\mathrm{H} 3+\mathrm{C} 2 \mathrm{H} 5$ & & 4. $\odot \odot E+13$ & $\odot . \odot$ & -550.0 \\
\hline 187. & $\mathrm{CH} 3+02<=>\mathrm{OH}+\mathrm{CH} 2$ & & & $2.31 E+12$ & $\odot . \odot$ & 20315.0 \\
\hline 188. & $\mathrm{CH} 3+\mathrm{H} 2 \mathrm{O} 2<=>\mathrm{HO} 2+$ & $\mathrm{CH} 4$ & & $2.45 \mathrm{E}+\odot 4$ & 2.5 & 5180.0 \\
\hline 189. & $2 \mathrm{CH} 3(+\mathrm{M})<=>\mathrm{C} 2 \mathrm{H} 6$ & $(+M)$ & & $6.77 E+16$ & -1.2 & 654.0 \\
\hline & Low pressure lir & $\odot .34000 \mathrm{E}+42$ & $2-\odot .70300 \mathrm{E}+\odot 1$ & $\odot .27620 \mathrm{E}+\odot$ & & \\
\hline & TROE centering: & $\odot .619 \odot \odot \mathrm{E}+\odot \odot$ & $\odot \quad \odot .7320 \odot \mathrm{E}+\odot 2$ & $\odot .11800 \mathrm{E}+\odot$ & & ๑. 99990E+๑4 \\
\hline & $\mathrm{H} 2$ & Enhanced by 2 & $2 . \odot \odot \odot E+\odot \odot$ & & & \\
\hline & $\mathrm{H} 2 \mathrm{O}$ & Enhanced by & $6.000 E+00$ & & & \\
\hline & $\mathrm{CH} 4$ & Enhanced by & $2 . \odot \odot \odot E+\odot \odot$ & & & \\
\hline & $\mathrm{CO}$ & Enhanced by & $1.500 \mathrm{E}+00$ & & & \\
\hline & $\mathrm{CO} 2$ & Enhanced by & $2.0 \odot \odot E+\odot \odot$ & & & \\
\hline & $\mathrm{C} 2 \mathrm{H} 6$ & Enhanced by & 3. $\odot \odot \odot E+\odot \odot ~$ & & & \\
\hline & AR & Enhanced by & 7. $\odot \odot \odot E-\odot 1$ & & & \\
\hline 190. & $\mathrm{CH} 3+\mathrm{HCO}<=>\mathrm{CH} 4+\mathrm{C}$ & & & $2.65 E+13$ & $\odot . \odot$ & $\odot . \odot$ \\
\hline 191. & $\mathrm{CH} 3+\mathrm{CH} 2 \mathrm{O}<=>\mathrm{HCO}+$ & $\mathrm{CH} 4$ & & $3.32 E+03$ & 2.8 & 5860.0 \\
\hline 192. & $\mathrm{CH} 3+\mathrm{CH} 3 \mathrm{OH}<=>\mathrm{CH} 2$ & $\mathrm{OH}+\mathrm{CH} 4$ & & 3. $\odot \odot E+\odot 7$ & 1.5 & 9940.0 \\
\hline 193. & $\mathrm{CH} 3+\mathrm{CH} 3 \mathrm{OH}<=>\mathrm{CH} 3$ & $\mathrm{O}+\mathrm{CH} 4$ & & 1. $\odot \odot E+\odot 7$ & 1.5 & 9940.0 \\
\hline 194. & $\mathrm{CH} 3+\mathrm{C} 2 \mathrm{H} 4<=>\mathrm{C} 2 \mathrm{H} 3$ & $+\mathrm{CH} 4$ & & $2.27 E+05$ & 2.0 & $9200 . \odot$ \\
\hline 195. & $\mathrm{CH} 3+\mathrm{C} 2 \mathrm{H}_{6}<=>\mathrm{C} 2 \mathrm{H}_{5}$ & $+\mathrm{CH} 4$ & & $6.14 \mathrm{E}+06$ & 1.7 & 10450.0 \\
\hline 196. & $\mathrm{HCO}+\mathrm{H} 2 \mathrm{O}<=>\mathrm{H}+\mathrm{CO}+\mathrm{H}$ & $\mathrm{H} 2 \mathrm{O}$ & & $1.50 \mathrm{E}+18$ & -1.0 & $17000 . \odot$ \\
\hline 197. & $\mathrm{HCO}+\mathrm{M}<=>\mathrm{H}+\mathrm{CO}+\mathrm{M}$ & & & $1.87 \mathrm{E}+17$ & -1.0 & 17000.0 \\
\hline & $\mathrm{H} 2$ & Enhanced by & 2. .०००E+०० & & & \\
\hline & $\mathrm{H} 2 \mathrm{O}$ & Enhanced by & $\odot . \odot \odot \odot E+\odot \odot$ & & & \\
\hline & $\mathrm{CH} 4$ & Enhanced by & $2.000 E+00$ & & & \\
\hline & CO & Enhanced by & 1. $500 \mathrm{E}+\odot \odot$ & & & \\
\hline & $\mathrm{CO} 2$ & Enhanced by & 2. $\odot \odot \odot E+\odot \odot$ & & & \\
\hline & $\mathrm{C} 2 \mathrm{H} 6$ & Enhanced by & 3. $\odot \odot \odot E+\odot \odot$ & & & \\
\hline 198. & $\mathrm{HCO}+02<=>\mathrm{HO} 2+\mathrm{CO}$ & & & $1.35 E+13$ & $\odot . \odot$ & 400.0 \\
\hline 199. & $\mathrm{CH} 2 \mathrm{OH}+02<=>\mathrm{HO} 2+$ & $\mathrm{CH} 2 \mathrm{O}$ & & $1.80 \mathrm{E}+13$ & $\odot .0$ & 900.0 \\
\hline 200. & $\mathrm{CH} 3 \mathrm{O}+02<=>\mathrm{HO} 2+\mathrm{Cl}$ & -120 & & $4.28 E-13$ & 7.6 & -3530.0 \\
\hline 201. & $\mathrm{C} 2 \mathrm{H}+02<=>\mathrm{HCO}+\mathrm{CO}$ & & & 1. $00 \mathrm{E}+13$ & $\odot . \odot$ & -755.0 \\
\hline 202. & $\mathrm{C} 2 \mathrm{H}+\mathrm{H} 2<=>\mathrm{H}+\mathrm{C} 2 \mathrm{H} 2$ & & & $5.68 \mathrm{E}+10$ & 0.9 & 1993.0 \\
\hline 203. & $\mathrm{C} 2 \mathrm{H} 3+02<=>\mathrm{HCO}+\mathrm{Cl}$ & -120 & & $4.58 E+16$ & -1.4 & 1015.0 \\
\hline 204 . & $\mathrm{C} 2 \mathrm{H} 4(+\mathrm{M})<=>\mathrm{H} 2+\mathrm{C}$ & $2 \mathrm{H} 2(+\mathrm{M})$ & & 8. $.0 E+12$ & 0.4 & 86770.0 \\
\hline & Low pressure lir & nit: $\quad 0.15800 E+52$ & $2-\odot .930 \odot \odot E+\odot 1$ & $\odot .97800 \mathrm{E}+\odot$ & & \\
\hline
\end{tabular}




\begin{tabular}{|c|c|c|c|c|c|c|}
\hline \multicolumn{3}{|r|}{$\odot .73450 \mathrm{E}+\odot \odot$} & $\odot .1800 \odot \mathrm{E}+\odot 3$ & $\odot .10350 \mathrm{E}+\odot 4$ & \multicolumn{2}{|c|}{$\odot .54170 \mathrm{E}+04$} \\
\hline & $\mathrm{H} 2$ & Enhanced by 2 & $.000 E+\odot \odot$ & & & \\
\hline & $\mathrm{H} 2 \mathrm{O}$ & Enhanced by & $. \odot \odot \odot E+\odot \odot$ & & & \\
\hline & $\mathrm{CH} 4$ & Enhanced by & $.0 \odot \odot E+\odot \odot$ & & & \\
\hline & $\mathrm{CO}$ & Enhanced by & $.500 \mathrm{E}+00$ & & & \\
\hline & $\mathrm{CO} 2$ & Enhanced by & $. \odot \odot \odot E+\odot \odot$ & & & \\
\hline & $\mathrm{C} 2 \mathrm{H} 6$ & Enhanced by & $.000 E+0 \odot$ & & & \\
\hline & AR & Enhanced by & $.000 \mathrm{E}-01$ & & & \\
\hline 205. & \multicolumn{3}{|c|}{$\mathrm{C} 2 \mathrm{H} 5+02<=>\mathrm{HO} 2+\mathrm{C} 2 \mathrm{H} 4$} & $8.40 E+11$ & 0.0 & 3875.0 \\
\hline 206. & \multicolumn{3}{|c|}{$\mathrm{HCCO}+02<=>0 \mathrm{H}+2 \mathrm{CO}$} & 3. $20 \mathrm{E}+12$ & $\odot . \odot$ & 854.0 \\
\hline 207. & \multicolumn{3}{|l|}{$2 \mathrm{HCCO}<=>2 \mathrm{CO}+\mathrm{C} 2 \mathrm{H} 2$} & 1. $\odot \odot E+13$ & $\odot . \odot$ & $\odot . \odot$ \\
\hline 208. & \multicolumn{3}{|l|}{$\mathrm{O}+\mathrm{CH} 3=>\mathrm{H}+\mathrm{H} 2+\mathrm{CO}$} & $3.37 E+13$ & $\odot .0$ & 0.0 \\
\hline 209. & \multicolumn{3}{|l|}{$\mathrm{O}+\mathrm{C} 2 \mathrm{H} 4<=>\mathrm{H}+\mathrm{CH} 2 \mathrm{CHO}$} & $6.70 E+06$ & 1.8 & 220.0 \\
\hline 210. & \multicolumn{3}{|l|}{$\mathrm{O}+\mathrm{C} 2 \mathrm{H} 5<=>\mathrm{H}+\mathrm{CH} 3 \mathrm{CHO}$} & $1.10 \mathrm{E}+14$ & $\odot . \odot$ & $\odot . \odot$ \\
\hline 211. & \multicolumn{3}{|c|}{$\mathrm{OH}+\mathrm{H} 02<=>02+\mathrm{H} 20$} & \multicolumn{3}{|c|}{ Declared duplicate reaction... } \\
\hline 212. & \multicolumn{3}{|c|}{$\mathrm{OH}+\mathrm{CH} 3=>\mathrm{H} 2+\mathrm{CH} 2 \mathrm{O}$} & 8. .०E+०9 & 0.5 & -1755.0 \\
\hline 213. & \multirow{2}{*}{\multicolumn{3}{|c|}{$\mathrm{CH}+\mathrm{H} 2(+\mathrm{M})<=>\mathrm{CH} 3(+\mathrm{M})$}} & 1. $97 \mathrm{E}+12$ & 0.4 & -370.0 \\
\hline & & $\odot .48200 E+26$ & $-\odot .280 \odot \odot E+\odot 1$ & \multicolumn{3}{|c|}{$\odot .59000 \mathrm{E}+03$} \\
\hline & & \multicolumn{2}{|c|}{ 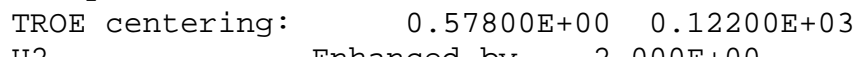 } & $\odot .25350 \mathrm{E}+\odot 4$ & & $650 E+\odot 4$ \\
\hline & $\mathrm{H} 2$ & Enhanced by 2 & $.0 \odot \odot E+\odot \odot$ & & & \\
\hline & $\mathrm{H} 2 \mathrm{O}$ & Enhanced by & $. \odot \odot \odot E+\odot \odot$ & & & \\
\hline & $\mathrm{CH} 4$ & Enhanced by & $.0 \odot \odot E+\odot \odot$ & & & \\
\hline & $\mathrm{CO}$ & Enhanced by & $.500 E+\odot \odot$ & & & \\
\hline & $\mathrm{CO} 2$ & Enhanced by & $. \odot \odot \odot E+\odot \odot$ & & & \\
\hline & $\mathrm{C} 2 \mathrm{H} 6$ & Enhanced by & $. \odot \odot \odot E+\odot \odot$ & & & \\
\hline & AR & Enhanced by & $.0 \odot \odot E-01$ & & & \\
\hline 214. & $\mathrm{CH} 2+02=>2 \mathrm{H}+\mathrm{CO} 2$ & & & $5.80 E+12$ & $\odot . \odot$ & 1500.0 \\
\hline 215. & $\mathrm{CH} 2+02<=>0+\mathrm{CH} 2 \mathrm{O}$ & & & 2. $40 E+12$ & $\odot . \odot$ & 1500.0 \\
\hline 216. & $\mathrm{CH} 2+\mathrm{CH} 2=>2 \mathrm{H}+\mathrm{C} 2 \mathrm{H}_{2}$ & & & $2.00 \mathrm{E}+14$ & $\odot . \odot$ & 10989.0 \\
\hline 217. & $\mathrm{CH} 2(\mathrm{~S})+\mathrm{H} 2 \mathrm{O}=>\mathrm{H} 2+\mathrm{C}$ & $\mathrm{CH} 2 \mathrm{O}$ & & $6.82 E+10$ & 0.3 & -935.0 \\
\hline 218. & $\mathrm{C} 2 \mathrm{H} 3+02<=>0+C H 2 C$ & $\mathrm{CHO}$ & & $3.03 E+11$ & 0.3 & 11.0 \\
\hline 219. & $\mathrm{C} 2 \mathrm{H}_{3}+02<=>\mathrm{HO}_{2}+\mathrm{C} 2$ & $2 \mathrm{H} 2$ & & $1.34 \mathrm{E}+06$ & 1.6 & -384.0 \\
\hline 220. & $\mathrm{O}+\mathrm{CH} 3 \mathrm{CHO}<=>\mathrm{OH}+\mathrm{Cl}$ & $+2 \mathrm{CHO}$ & & $2.92 \mathrm{E}+12$ & 0.0 & 1808.0 \\
\hline 221. & $\mathrm{O}+\mathrm{CH} 3 \mathrm{CHO}=>\mathrm{OH}+\mathrm{CH} 3$ & $3+C 0$ & & $2.92 E+12$ & $\odot . \odot$ & 1808.0 \\
\hline 222. & $\mathrm{O} 2+\mathrm{CH} 3 \mathrm{CHO}=>\mathrm{HO} 2+\mathrm{C}$ & $\mathrm{CH} 3+\mathrm{CO}$ & & $3.01 E+13$ & $\odot . \odot$ & 39150.0 \\
\hline 223. & $\mathrm{H}+\mathrm{CH} 3 \mathrm{CHO}<=>\mathrm{CH} 2 \mathrm{Cl}$ & $\mathrm{HO}+\mathrm{H} 2$ & & $2.05 E+09$ & 1.2 & 2405.0 \\
\hline 224. & $\mathrm{H}+\mathrm{CH} 3 \mathrm{CHO}=>\mathrm{CH} 3+\mathrm{H}_{2}$ & $2+\mathrm{CO}$ & & $2.05 E+09$ & 1.2 & 2405.0 \\
\hline 225. & $\mathrm{OH}+\mathrm{CH} 3 \mathrm{CHO}=>\mathrm{CH} 3+\mathrm{r}$ & $120+C 0$ & & $2.34 \mathrm{E}+10$ & 0.7 & -1113.0 \\
\hline 226. & $\mathrm{HO} 2+\mathrm{CH} 3 \mathrm{CHO}=>\mathrm{CH} 3+$ & $+\mathrm{H} 2 \mathrm{O} 2+\mathrm{CO}$ & & $3.01 E+12$ & $\odot . \odot$ & 11923.0 \\
\hline 227. & $\mathrm{CH} 3+\mathrm{CH} 3 \mathrm{CHO}=>\mathrm{CH} 3+$ & $\mathrm{CH} 4+\mathrm{CO}$ & & $2.72 E+06$ & 1.8 & 5920.0 \\
\hline 228. & $\mathrm{H}+\mathrm{CH} 2 \mathrm{CO}(+\mathrm{M})<=>\mathrm{Cl}$ & $\mathrm{H} 2 \mathrm{CHO}(+\mathrm{M})$ & & $4.87 \mathrm{E}+11$ & 0.4 & -1755.0 \\
\hline & Low pressure lin & nit: $\quad 0.10120 E+43$ & $-0.76300 E+01$ & $\odot .3854 \odot E+\odot 4$ & & \\
\hline & TROE centering: & $\odot .4650 \odot E+\odot \odot$ & $0.20100 \mathrm{E}+03$ & $\odot .17730 \mathrm{E}+\odot 4$ & & $330 E+\odot 4$ \\
\hline & $\mathrm{H} 2$ & Enhanced by 2 & $. \odot \odot \odot E+\odot \odot$ & & & \\
\hline & $\mathrm{H} 2 \mathrm{O}$ & Enhanced by & ค. ๑७०Е+०७ & & & \\
\hline & $\mathrm{CH} 4$ & Enhanced by & $.0 \odot \odot E+\odot \odot$ & & & \\
\hline & $\mathrm{CO}$ & Enhanced by & L. $500 \mathrm{E}+0 \odot$ & & & \\
\hline & $\mathrm{CO} 2$ & Enhanced by & $.0 \odot \odot E+\odot \odot$ & & & \\
\hline & $\mathrm{C} 2 \mathrm{H} 6$ & Enhanced by & 3. $.00 E+0 \odot$ & & & \\
\hline & AR & Enhanced by & $.0 \odot \odot E-01$ & & & \\
\hline 229. & $\mathrm{O}+\mathrm{CH} 2 \mathrm{CHO}=>\mathrm{H}+\mathrm{CH} 2+$ & -CO2 & & $1.50 \mathrm{E}+14$ & $\odot . \odot$ & $\odot . \odot$ \\
\hline 230. & $\mathrm{O} 2+\mathrm{CH} 2 \mathrm{CHO}=>\mathrm{OH}+\mathrm{CC}$ & $+\mathrm{CH} 2 \mathrm{O}$ & & $1.81 E+10$ & $\odot . \odot$ & 0.0 \\
\hline 231. & $\mathrm{O} 2+\mathrm{CH} 2 \mathrm{CHO}=>\mathrm{OH}+2 \mathrm{H}$ & †CO & & $2.35 E+10$ & $\odot . \odot$ & $\odot . \odot$ \\
\hline 232. & $\mathrm{H}+\mathrm{CH} 2 \mathrm{CHO}<=>\mathrm{CH} 3+\mathrm{H}$ & †CO & & $2.20 \mathrm{E}+13$ & 0.0 & $\odot . \odot$ \\
\hline 233. & $\mathrm{H}+\mathrm{CH} 2 \mathrm{CHO}<=>\mathrm{CH} 2 \mathrm{CC}$ & $+\mathrm{H} 2$ & & 1.10E+13 & 0.0 & $\odot . \odot$ \\
\hline 234. & $\mathrm{OH}+\mathrm{CH} 2 \mathrm{CHO}<=>\mathrm{H} 2 \mathrm{O}+$ & $\mathrm{H}+\mathrm{H} 2 \mathrm{CO}$ & & 1. $20 \mathrm{E}+13$ & 0.0 & $\odot . \odot$ \\
\hline 235. & $\mathrm{OH}+\mathrm{CH} 2 \mathrm{CHO}<=>\mathrm{HCO}+$ & $+\mathrm{CH} 2 \mathrm{OH}$ & & $3.01 E+13$ & $\odot .0$ & $\odot . \odot$ \\
\hline 236. & $\mathrm{CH} 3+\mathrm{C} 2 \mathrm{H} 5(+\mathrm{M})<=>\mathrm{C}$ & $3 \mathrm{H} 8(+\mathrm{M})$ & & $9.43 E+12$ & $\odot . \odot$ & $\odot .0$ \\
\hline & Low pressure lin & nit: $\quad 0.27100 E+75$ & $-\odot .16820 E+02$ & $0.13065 \mathrm{E}+05$ & & \\
\hline & TROE centering: & $\odot .15270 \mathrm{E}+\odot \odot$ & ๑. 29100E+०3 & $\odot .27420 E+\odot 4$ & & $480 E+04$ \\
\hline
\end{tabular}




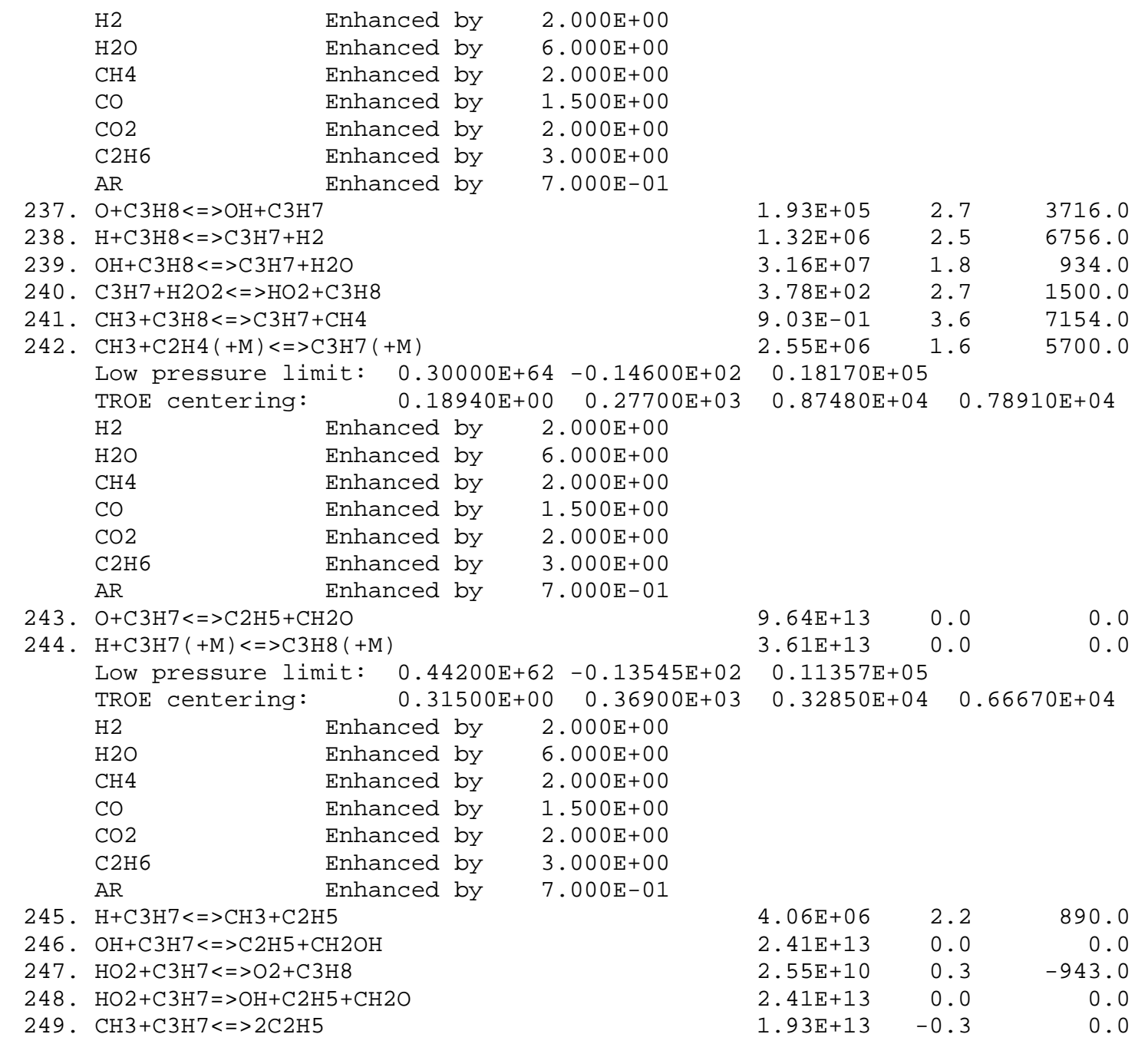

NOTE: A units mole-cm-sec-K, E units cal/mole 


\section{LIST OF REFERENCES}

1. Higgins, B.; McQuay, M. Q.; Lacas, F.; Rolon, J. C.; Darabiha, N.; and Candel, S. "Systematic Measurements of OH-Chemiluminescence for Fuel-Lean, High-Pressure, Pre-Mixed Laminar Flames,” Fuel, Vol. 80, 2001, No. 1, pp. 67-74.

2. Asaba, T.; Gardiner, W. C. Jr.; and Stubbeman, R. F. "Shock-Tube Study of the HydrogenOxygen Reaction” Proceedings of the Combustion Institute, Vol. 10, 1965, pp. 295-302.

3. Seery, D. J.; and Bowman C. T. "An Experimental and Analytical Study of Methane Oxidation Behind Shock Waves," Combustion and Flame, Vol. 14, 1970, pp. 37-48.

4. Petersen, E. L.; Kalitan, D. M.; and Rickard, M. J. A. "Reflected-Shock Ignition of $\mathrm{SiH}_{4} / \mathrm{H}_{2} / \mathrm{O}_{2}$ and $\mathrm{SiH}_{4} / \mathrm{CH}_{4} / \mathrm{O}_{2} / \mathrm{Ar}$ Mixtures," Journal of Propulsion and Power, Vol. 20, 2004, pp. 665-674.

5. Muruganandam, T. M.; Kim, B. H.; Morrell, M. R.; Nori, V.; Patel, M.; Romig, B. W.; and Seitzman, J. M. "Optical Equivalence Ratio Sensors for Gas Turbine Combustors," Proceedings of the Combustion Institute, Vol. 30, 2005, pp. 1601-1609.

6. Hardalupus, Y.; and Orain, M. "Local Measurements of the Time-Dependent Heat Release Rate and Equivalence Ratio Using Chemiluminescent Emission from a Flame," Combustion and Flame, Vol. 139, 2004, pp. 188-207.

7. Gaydon, A. G. The Spectroscopy of Flames, Chapman and Hall, London, 1957.

8. Charton, M.; and Gaydon, A. G. "Excitation of Spectra of OH in Hydrogen Flames and Its Relation to Excess Concentrations of Free Atoms," Proceedings of the Royal Society of London A, Mathematical and Physical Sciences, Vol. 245, 1958, pp. 84-92. 
9. Kaskan, W. E. "Abnormal Excitation of $\mathrm{OH}$ in $\mathrm{H}_{2} / \mathrm{O}_{2} / \mathrm{N}_{2}$ Flames," The Journal of Chemical Physics, Vol. 31, 1959, pp. 944-956.

10. Zeegers, P. J. TH.; and Alkemade, C. TH. J. "Chemiluminescence of OH Radicals and K Atoms By Radical Recombination in Flames," Proceedings of the Combustion Institute, Vol. 10, 1965, pp. 33-40.

11. Ticktin, S.; Spindler, G.; and Schiff, H. I. "Production of Excited $\mathrm{OH}\left(\mathrm{A}^{2} \Sigma^{+}\right)$Molecules by the Association of Ground-State Oxygen and Hydrogen Atoms," Discussions of the Faraday Society, Vol. 44, 1967, pp. 218-240.

12. Hollander, $\mathrm{Tj}$. "Photometric Measurements on the Deviations from the Equilibrium State in Flames," AIAA Journal, Vol. 6, No. 3, 1968, pp. 385-393.

13. Davis, M. G.; McGregor, W. K.; and Mason, A. A. “OH Chemiluminescent Radiation from Lean Hydrogen-Oxygen Flames,” The Journal of Chemical Physics, Vol. 61, No. 4, 1974, pp. 1352-1356.

14. Smith, G. P.; Luque, J.; Park, C.; Jeffries, J. B.; and Crosley, D. R. "Low Pressure Flame Determinations of Rate Constants for $\mathrm{OH}(\mathrm{A})$ and $\mathrm{CH}(\mathrm{A})$ Chemiluminescence," Combustion and Flame, Vol. 131, No. 1-2, 2002, pp. 59-69.

15. Smith, G. P.; Park, C.; and Luque, J. "A Note on Chemiluminescence in Low-Pressure Hydrogen and Methane-Nitrous Oxide Flames," Combustion and Flame, Vol. 140, 2005, pp. $385-389$.

16. Belles, F. E.; and Lauver, M. R. "Origin of $\mathrm{OH}$ Chemiluminescence During the Induction Period of the $\mathrm{H}_{2}-\mathrm{O}_{2}$ Reaction Behind Shock Waves," The Journal of Chemical Physics, Vol. 40, No. 2, 1964, pp. 415-422. 
17. Gutman, D.; Lutz, R. W.; Jacobs, N. F.; Hardwidge, E. A.; and Schott, G. L. "Shock-Tube Study of $\mathrm{OH}$ Chemiluminescence in the Hydrogen-Oxygen Reaction," The Journal of Chemical Physics, Vol. 48, No. 12, 1968, pp. 5689-5694.

18. Gardiner, W. C. Jr.; Morinaga, K.; Ripley, D. L.; and Takeyama, T. "Shock-Tube Study of $\mathrm{OH}\left({ }^{2} \Sigma-{ }^{2} \Pi\right)$ Luminescence," The Physics of Fluids Supplement, Vol. 1, 1969, pp. 120-124.

19. Hidaka, Y.; Takahashi, S.; Kawano, H.; Suga, M.; and Gardiner, W. C. Jr. "Shock Tube Measurement of the Rate Constant for Excited $\mathrm{OH}\left(\mathrm{A}^{2} \Sigma^{+}\right)$Formation in the HydrogenOxygen Reaction," The Journal of Physical Chemistry, Vol. 86, 1982, pp. 1429-1433.

20. Koike, T.; and Morinaga, K. "Further Studies of the Rate Constant for Chemical Excitation of OH in Shock Waves," Bulletin of the Chemical Society of Japan, Vol. 55, No. 1, 1982, pp. $52-54$.

21. Paul, P. H.; Durant, J. L. Jr.; Gray, J. A.; and Furlanetto, M. R. "Collisional Electronic Quenching of $\mathrm{OH} \mathrm{A}^{2} \Sigma\left(v^{\prime}=0\right)$ Measured at High Temperature in a Shock Tube," The Journal of Chemical Physics, Vol. 102, No. 21, 1995, pp. 8378-8384.

22. Carl, S. A.; Van Poppel, M.; and Peeters, J. "Identification of the $\mathrm{CH}+\mathrm{O}_{2} \rightarrow \mathrm{OH}(\mathrm{A})+\mathrm{CO}$ Reaction as the Source of $\mathrm{OH}(\mathrm{A}-\mathrm{X})$ Chemiluminescence in $\mathrm{C}_{2} \mathrm{H}_{2} / \mathrm{O} / \mathrm{H} / \mathrm{O}_{2}$ Atomic Flames and Determination of Its Absolute Rate Constant Over the Range T $=296$ to $511 \mathrm{~K}$," Journal of Physical Chemistry A, Vol. 107, 2003, pp. 11001-11007.

23. Grebe, J.; and Homann, K. H., "Kinetics of the Species $\mathrm{OH}\left(\mathrm{A}^{2} \Sigma^{+}\right), \mathrm{OH}\left(\mathrm{X}^{2} \Pi\right)$ and $\mathrm{CH}\left(\mathrm{X}^{2} \Pi\right)$ in the System $\mathrm{C}_{2} \mathrm{H}_{2} / \mathrm{O} / \mathrm{H}$," Berichte der Bunsen-Gesellschaft für Physikalische Chemie, Vol. 86, 1982, pp. 581-587. 
24. Lichtin, D. A.; Berman, M. R.; and Lin, M. C. "NH( $\left(\mathrm{A}^{3} \Pi \rightarrow \mathrm{X}^{3} \Sigma^{-}\right)$Chemiluminescence from the CH(X² $\Pi)+$ NO Reaction," Chemical Physics Letters, Vol. 108, No. 1, 1984, pp. 18-24.

25. Lichtin, D. A.; Berman, M. R.; and Lin, M. C., "Kinetic Studies of Laser Initiated Reactions of CH and CN Radicals,” Bulletin des Sociétés Chimiques Belges, Vol. 92, No. 6-7, 1983, pg. 656.

26. Porter, R. P.; Clark, A. H.; Kaskan, W. E.; and Browne, W. E. "A Study of Hydrocarbon Flames," Proceedings of the Combustion Institute, Vol. 11, 1967, pp. 907-917.

27. Fairchild, P. W.; Smith, G. P.; Crosley, D. R. "Collisional Quenching of $\mathrm{A}^{2} \Sigma^{+} \mathrm{OH}$ at Elevated Temperatures," The Journal of Chemical Physics, Vol. 79, No. 4, 1983, pp. 17951807.

28. Esposti, A. D.; Werner, H. J. "Ab Initio Calculation of the $\mathrm{OH}\left(\mathrm{X}^{2} \Pi, \mathrm{A}^{2} \Sigma^{+}\right)+\mathrm{Ar}$ Potential Energy Surfaces and Quantum Scattering Studies of Rotational Energy Transfer in the OH( $\left(\mathrm{A}^{2} \Sigma^{+}\right)$State," The Journal of Chemical Physics, Vol. 93, No. 5, 1990, pp. 3351-3366.

29. Jörg, A.; Meier, U.; Kohse-Höinghaus, K. "Rotational Energy Transfer in $\mathrm{OH}\left(\mathrm{A}^{2} \Sigma^{+}, \mathrm{v}^{\prime}=0\right)$ : A Method for the Direct Determination of State-to-State Transfer Coefficients," The Journal of Chemical Physics, Vol. 93, No. 9, 1990, pp. 6453-6462.

30. Tamura, M.; Berg, P. A.; Harrington, J. E.; Luque, J.; Jeffries, J. B.; Smith, G. P.; Crosley, D. R. "Collisional Quenching of $\mathrm{CH}(\mathrm{A}), \mathrm{OH}(\mathrm{A})$, and $\mathrm{NO}(\mathrm{A})$ in Low Pressure Hydrocarbon Flames," Combustion and Flame, Vol. 114, 1998, pp. 502-514.

31. Petersen, E. L.; Rickard, M. J. A.; Crofton, M. W.; Abbey, E. D.; Traum, M. J.; Kalitan, D. M. "A Facility for Gas- and Condensed-Phase Measurements Behind Shock Waves" Measurement Science and Technology, Vol. 16, 2005, pp. 1716-1729. 
32. Petersen, E. L.; Welle, R.; Traum, M.; Abbey, E.; and Rickard, M. J. A., "A New ShockTube Facility for Studying Combustion Phenomena in Mixtures Containing Condensed Species," Paper NHTC2001-20136, Proceedings of NHTC'01, 35 ${ }^{\text {th }}$ National Heat Transfer Conference, June 10-12, 2001, Anaheim, CA.

33. Kee, R. J.; Rupley, F. M.; and Miller, J. A. The Chemkin Thermodynamic Database, SAND87-8215B, Sandia National Laboratory, March 1990.

34. Amadio, A. R.; de Vries, J.; Hall, J. M.; Petersen, E. L.; and Crofton, M. W. "Driver-gas Tailoring Using Unconventional Driver Mixtures" $25^{\text {th }}$ International Symposium on Shock Waves, July 2005, Bangalore, India.

35. Smith, G. P.; Golden, D. M.; Frenklach, M.; Moriarty, N. W.; Eiteneer, B.; Goldenberg, M.; Bowman, C. T.; Hanson, R. K.; Song, S.; Gardiner, W. C. Jr.; Lissianski, V. V.; and Qin, Z. GRI-Mech 3. 0, http://www.me.berkeley.edu/gri-mech/

36. Hall, J. M. and Petersen, E. L. "Kinetics of OH Chemiluminescence in the Presence of Hydrocarbons," AIAA paper 2004-4164, 2004.

37. Petersen, E. L.; Kalitan, D. M.; and Rickard, M. J. A. "Calibration and Chemical Kinetics Modeling of an OH Chemiluminescence Diagnostics,” AIAA paper 2003-4493, 2003.

38. de Vries, J.; Hall, J. M.; Rickard, M. J. A.; Simmons, S. F.; and Petersen, E. L. "Ethane Ignition and Oxidation Behind Shock Waves," submitted to Combustion and Flame, (2005) also in AIAA 2004-3370 (2004).

39. Hall, J. M. and Petersen, E. L. "Direct Determination of the Dominant $\mathrm{CH}(\mathrm{A})$ Formation Reaction and Its Rate Coefficient for $1200<\mathrm{T}<2300 \mathrm{~K}$," in preparation for submission to The Journal of Physical Chemistry, A, also in AIAA paper 2005-1318 (2005). 
40. Wang, H. and Laskin, A. "On Initiation Reactions of Acetylene Oxidation in Shock Tubes A Quantum Mechanical and Kinetic Modeling Study," Chemical Physics Letters, Vol. 303, 1999, pp. 43-49.

41. Li, S. C. and Williams, F. A.; "NO Combustion and Flame, Vol. 118, No. 3, 1999, pp. 399-414.

42. Williams, F. A., Center for Energy Research, Combustion Division, University of California San Diego, http://maeweb.ucsd.edu/ combustion/cermech/

43. Kalitan, D. M.; Hall, J. M.; and Petersen, E. L. "Ignition and Oxidation of EthyleneOxygen-Diluent Mixtures With and Without Silane Addition" Journal of Propulsion and Power, Vol. 21, No.6, November/December 2005, in press.

44. Rickard, M. J. A.; Hall, J. M.; and Petersen, E. L. "Effect of Silane Addition on Acetylene Ignition Behind Reflected Shock Waves," Proceedings of the Combustion Institute, Vol. 30, 2005, pp. 1915-1923.

45. Kee, R. J.; Rupley, F. M.; Miller, J. A.; Coltrin, M. E.; Grcar, J. F.; Meeks, E.; Moffat, H. K.; Lutz, A. E.; Dixon-Lewis, G.; Smooke, M. D.; Warnatz, J.; Evans, G. H.; Larson, R. S.; Mitchell, R. E.; Petzold, L. R.; Reynolds, W. C.; Caracotsios, M.; Stewart, W. E.; Glarborg, P.; Wang, C.; and Adigun, O. Chemkin Collection, Release 3.6, Reaction Design, Inc., San Diego, CA, 2000.

46. Turns, S. R. An Introduction to Combustion: Concepts and Applications, $2^{\text {nd }}$ Edition, McGraw-Hill 2000.

47. Hall, J. M. and Petersen, E. L. "A High-Pressure Kinetics Model for the Ignition of Natural Gas Fuel Blends,” AIAA paper 2006-0353 (2006). 
48. Petersen, E. L.; Davidson, D. F.; and Hanson, R. K. "Kinetics Modeling of Shock-Induced Ignition in Low-Dilution $\mathrm{CH}_{4} / \mathrm{O}_{2}$ Mixtures at High Pressures and Intermediate Temperatures," Combustion and Flame, Vol. 117, 1999, pp. 272-290.

49. Pilling, M. J. and Seakins, P. W. Reaction Kinetics, Oxford University Press, Oxford, 1995.

50. Wright, M. R. An Introduction to Chemical Kinetics, John Wiley \& Sons, Ltd, 2004.

51. Vincenti, W. G. and Kruger, C. H. Jr. Introduction to Physical Gas Dynamics John Wiley \& Sons, Inc. 1965. 